Florida International University FIU Digital Commons

7-12-2012

\title{
Dynamics of Ecosystem Metabolism and Flocculent Detritus Transport in Estuarine Taylor River
}

Gregory R. Koch

Florida International University, gkoch001@fiu.edu

DOI: $10.25148 /$ etd.FI12080602

Follow this and additional works at: https://digitalcommons.fiu.edu/etd

\section{Recommended Citation}

Koch, Gregory R., "Dynamics of Ecosystem Metabolism and Flocculent Detritus Transport in Estuarine Taylor River" (2012). FIU Electronic Theses and Dissertations. 680.

https://digitalcommons.fiu.edu/etd/680 


\title{
FLORIDA INTERNATIONAL UNIVERSITY
}

Miami, Florida

\section{DYNAMICS OF ECOSYSTEM METABOLISM AND FLOCCULENT DETRITUS}

TRANSPORT IN ESTUARINE TAYLOR RIVER

\author{
A dissertation submitted in partial fulfillment of \\ the requirements for the degree of \\ DOCTOR OF PHILOSOPHY \\ in \\ BIOLOGY
}

by

Gregory R. Koch

2012 
To: Dean Kenneth G. Furton

College of Arts and Sciences

This dissertation, written by Gregory R. Koch, and entitled Dynamics of Ecosystem Metabolism and Flocculent Detritus Transport in Estuarine Taylor River, having been approved in respect to style and intellectual content, is referred to you for judgment.

We have read this dissertation and recommend that it be approved.

Jennifer H. Richards

René M. Price

Stephen E. Davis III

Evelyn E. Gaiser, Co-Major Professor

Daniel L. Childers, Co-Major Professor

Date of Defense: July 12, 2012

The dissertation of Gregory R. Koch is approved.

\begin{tabular}{r}
\hline $\begin{array}{c}\text { Dean Kenneth G. Furton } \\
\text { College of Arts and Sciences }\end{array}$ \\
\hline Dean Lakshmi N. Reddi \\
University Graduate School
\end{tabular}

Florida International University, 2012 


\section{DEDICATION}

I dedicate this dissertation to my father, David Robert Koch, who instilled in me a passionate curiosity of our natural world. I love you; rest in peace. 


\section{ACKNOWLEDGMENTS}

I thank Veronica Jubera Maldonado for her unending love and companionship. I would also like to thank my family for their enduring support during my graduate research program: my father David R. Koch, my mother Susan E. Koch and her husband Mark C. Irick, my brother Michael R. Koch, my uncle J. Richard Koch, my aunt Deborah Koch, my cousin Benjamin Koch and his wife Christina, and my grandmothers Orpha Koch and Betty Swisher. I also thank Julio Jubera Diaz, Marta Maldonado de Jubera, and Melissa Jubera Maldonado for their continued, gracious support.

I also thank all of my friends who have shared their lives with me over the years: Adam Forrer and his wonderful family, Edward Waxler, Phuc Van Nguyen, Jeff and Kate Wozniak, David Iwaniec and Chloe Beauford, Damon and Amy Rondeau, Greg Losada and Oliva Pisani, Tiffany Troxler, Patrick Gibson, Barry Sparkman, Colin Saunders, Sharon Ewe, Rafael Travieso, Samantha Evans, Flavia Carniero, Clayton Williams, Jay Munyon, Cayelan Carey, Taylor Collison and Elizabeth Trenkle, Shane Proch-Wilson and Michael Aubuchon, and Sam Pond.

I am indebted to my committee members for their guidance throughout my research: Evelyn Gaiser, Stephen Davis, Rene Price, and Jenny Richards. I especially thank Dan Childers for taking me under his wing as a fledgling scientist and whose unwavering confidence in my abilities supported me when I needed it most. I also thank Peter Staehr for his selfless support of my research and David Osgood for introducing me to ecological research.

I would like to acknowledge support from the Florida International University Dissertation Year Fellowship, the Everglades Foundation Graduate Fellowship, as well as 
the Global Lakes Ecological Observatory Network (GLEON) and the National Science Foundation Long-Term Ecological Research Program. This dissertation research would not have been possible without the cooperation of Everglades National Park, the South Florida Water Management District, and the United States Geological Survey. I thank all of you from the bottom of my heart. 


\title{
ABSTRACT OF THE DISSERTATION \\ DYNAMICS OF ECOSYSTEM METABOLISM AND FLOCCULENT DETRITUS \\ TRANSPORT IN ESTUARINE TAYLOR RIVER
}

\author{
by
}

Gregory R. Koch

Florida International University, 2012

Miami, Florida

\section{Professor Daniel L. Childers, Major Professor}

Estuaries and estuarine wetlands are ecologically and societally important systems, exhibiting high rates of primary production that fuel offshore secondary production. Hydrological processes play a central role in shaping estuarine ecosystem structure and function by controlling nutrient loading and the relative contributions of marine and terrestrial influences on the estuary. The Comprehensive Everglades Restoration Plan includes plans to restore freshwater delivery to Taylor Slough, a shallow drainage basin in the southern Everglades, ultimately resulting in increased freshwater flow to the downstream Taylor River estuary. The existing seasonal and inter-annual variability of water flow and source in Taylor River affords the opportunity to investigate relationships between ecosystem function and hydrologic forcing.

Estimates of aquatic ecosystem metabolism, derived from free-water, diel changes in dissolved oxygen, were combined with assessments of wetland flocculent detritus quality and transport within the context of seasonal changes in Everglades hydrology. Variation in ecosystem gross primary production and respiration were linked to seasonal changes in estuarine water quality using multiple autoregression models. Furthermore, 
Taylor River was observed to be net heterotrophic, indicating that an allochthonous source of carbon maintained ecosystem respiration in excess of autochthonous primary production. Wetland-derived detritus appears to be an important vector of energy and nutrients across the Everglades landscape; and in Taylor River, is seasonally flushed into ponded segments of the river where it is then respired. Lastly, seasonal water delivery appears to govern feedbacks regulating water column phosphorus availability in the Taylor River estuary. 


\section{TABLE OF CONTENTS}

CHAPTER

PAGE

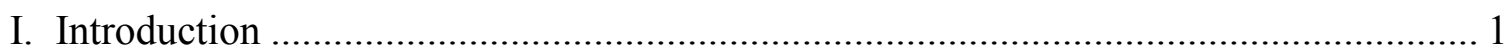

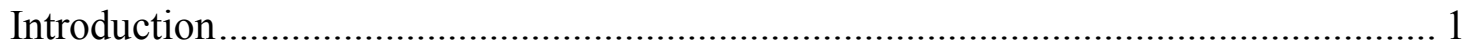

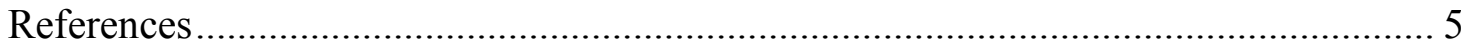

II. Hydrological conditions control P loading and aquatic metabolism in an oligotrophic,

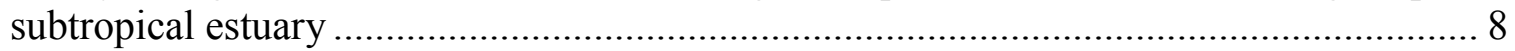

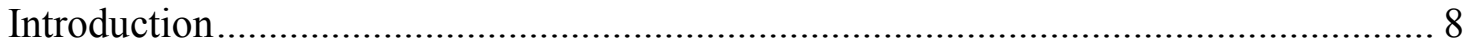

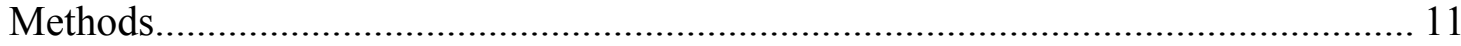

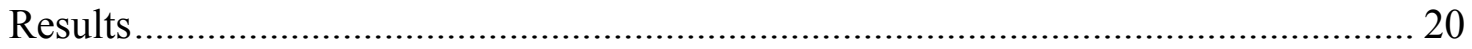

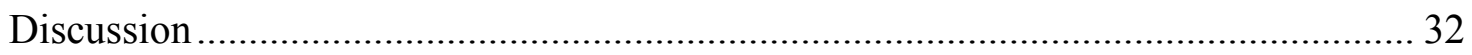

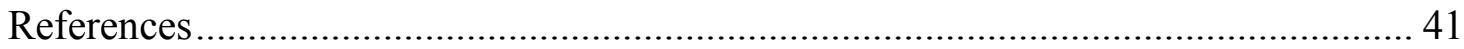

III. Ecological and physical characteristics of flocculent detritus in the Everglades: A

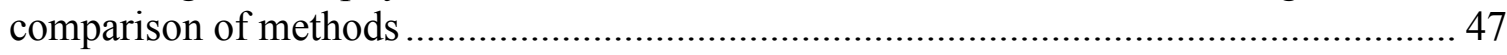

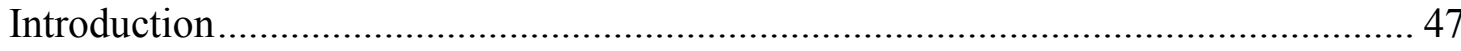

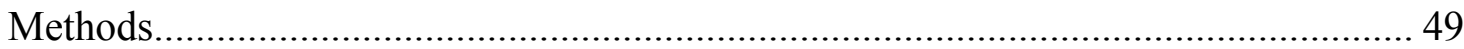

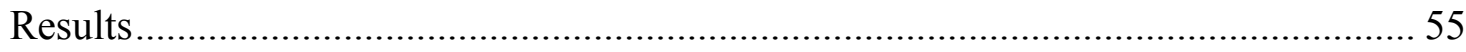

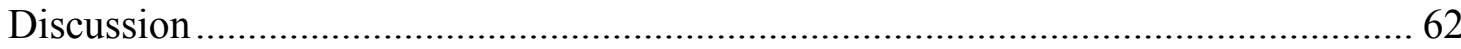

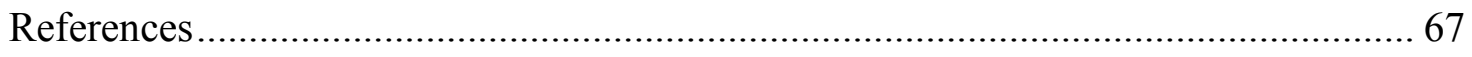

IV. Examining Flocculent Detritus Transport in an Estuarine Wetland Using a Sediment

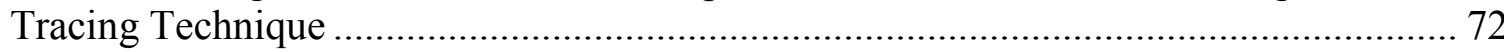

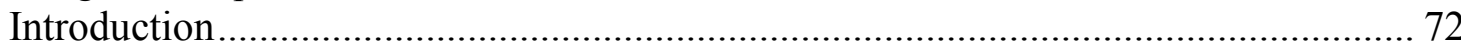

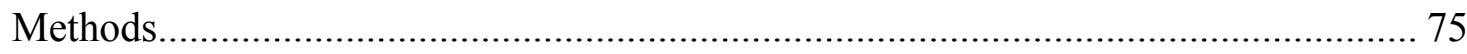

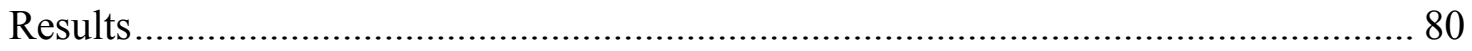

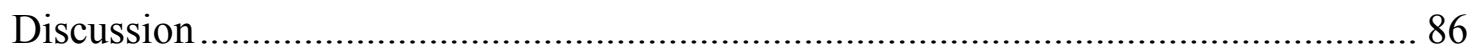

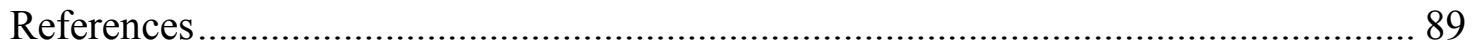

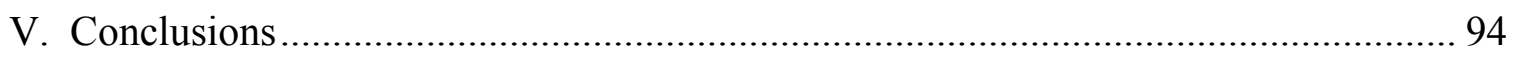

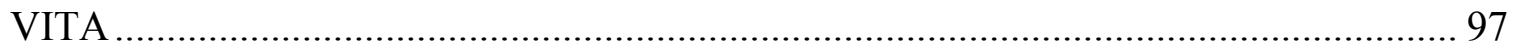




\section{LIST OF TABLES}

TABLE

PAGE

Chapter II

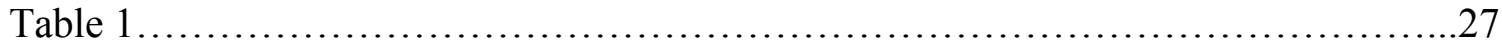

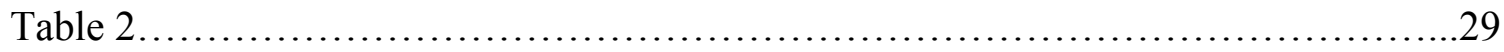

Chapter III

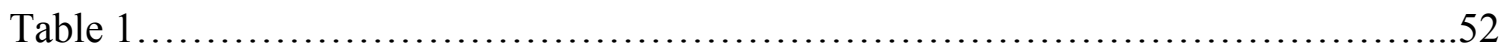

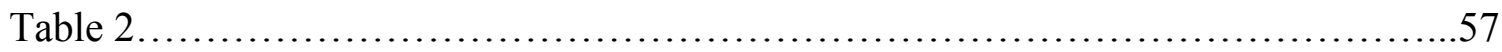

Chapter IV

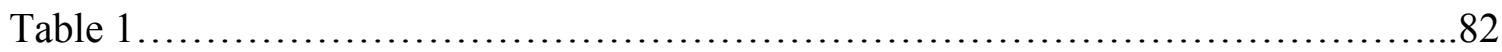

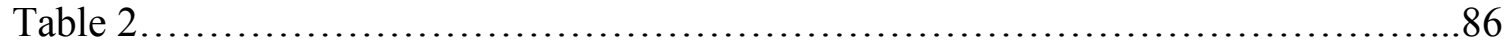




\section{LIST OF FIGURES}

FIGURE

PAGE

\section{Chapter I}

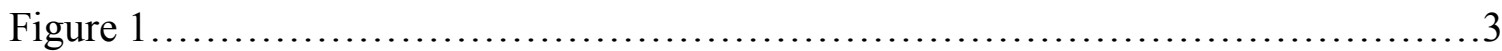

\section{Chapter II}

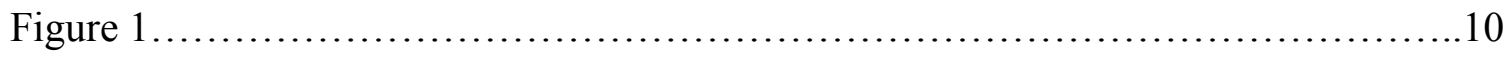

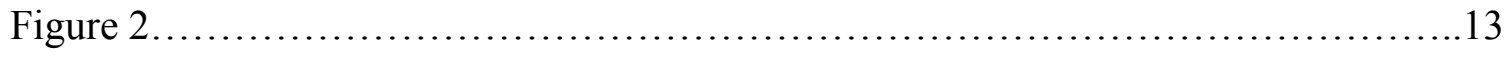

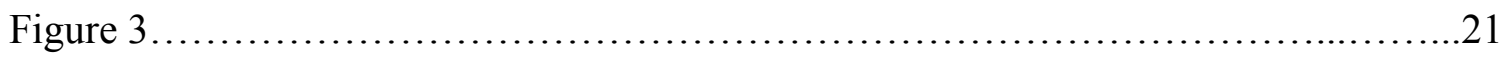

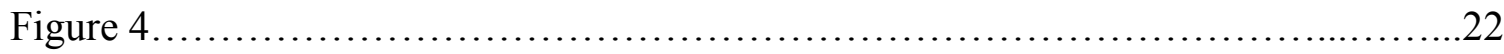

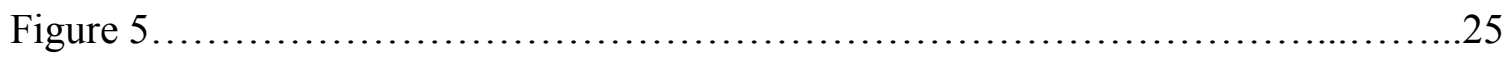

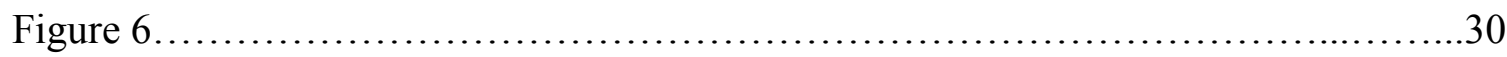

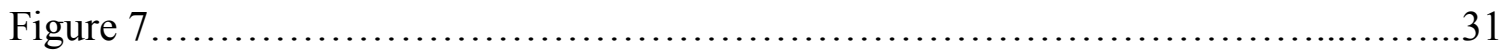

\section{Chapter III}

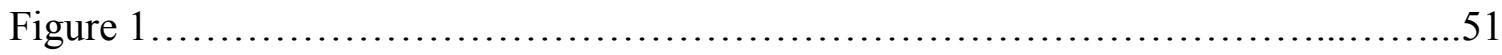

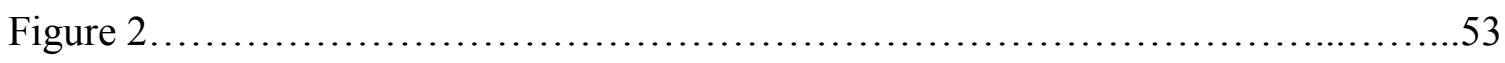

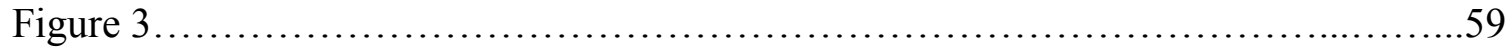

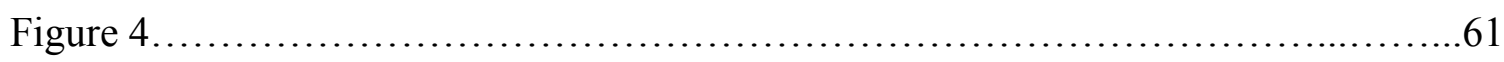

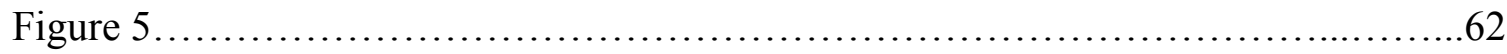

\section{Chapter IV}

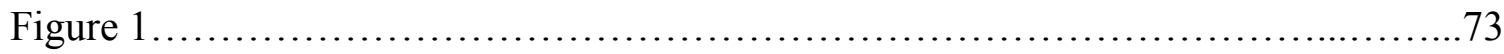

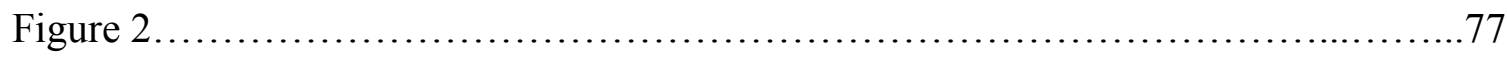

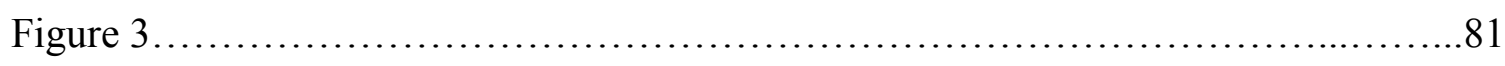

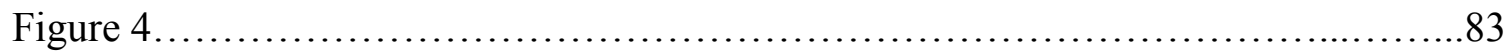




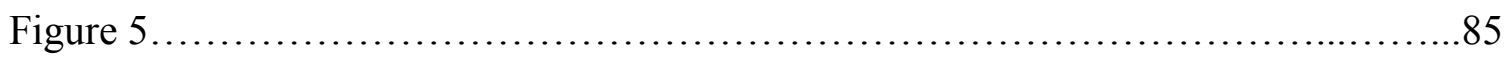




\section{LIST OF ABBREVIATIONS \& ACRONYMS}

$\mathrm{AICc}$

ANOVA

$\mathrm{C}$

CERP

ENSO

FCE LTER

GPP

$\mathrm{HCl}$

$\mathrm{N}$

NAVD88

NEP

NMDS

$\mathrm{OM}$

$\mathrm{P}$

PAR

POM

PSU

$\mathrm{R}$

SFWMD

SRS

SV

TP
Corrected Akaike’s Information Criterion

Analysis of Variance

Carbon

Comprehensive Everglades Restoration Program

El Niño/Southern Oscillation

Florida Coastal Everglades Long-Term Ecological Research

Gross Primary Production

Hydrochloric Acid

Nitrogen

North American Vertical Datum of 1988

Net Ecosystem Metabolism

Non-metric Multidimensional Scaling

Organic Matter

Phosphorus

Photosynthetically Active Radiation

Particulate Organic Matter

Practical Salinity Unit

Respiration

South Florida Water Management District Shark River Slough

Settling Velocity

Total Phosphorus 


\section{Introduction}

Introduction

Estuaries and estuarine wetlands lie at the interface of the land and the sea where freshwater from the terrestrial end-member mixes with saltwater from the marine endmember. Because they are locations where two resource pools are mixing, estuarine wetlands are often considered hotspots of biogeochemical cycling (McClain et al. 2003) and can be among the most productive ecosystems on the planet (Correll 1978, Nixon et al. 1986). Freshwater inputs from the terrestrial end-member of an estuary controls ecosystem function in two major ways. First, because these inputs integrate entire upstream watersheds, they supply the estuarine ecosystem with large amounts of organic, inorganic, dissolved, and particulate materials, including nutrients necessary for photosynthesis and primary production (Milliman and Syvitski 1992, Smith and Hollibaugh 1993, Hobbie 2000, Howarth et al. 2002). Terrestrially-supplied estuarine inputs are then transformed within the ecosystem into biomass and other organic products, which may be stored internally within the system or exported (i.e., estuarine outwelling) to adjacent marine ecosystems (Odum 1968, Odum et al. 1979, Odum 1980, Nixon 1980, Childers et al. 2000). Second, the magnitude of freshwater inputs to the estuary control the relative importance of the terrestrial vs. marine end-members and their associated hydrologic and water quality conditions.

The major estuaries of Everglades National Park (ENP) are supplied by two drainage basins: the Shark River Slough and the Taylor Slough (Fig. 1). Historically, water entered ENP wetlands as overland sheet flow that originated in the Kissimmee 
River basin, located in Central Florida, before flowing into Lake Okeechobee and then finally spilling over and flowing through Everglades marshes. This hydrologic pathway was much more pronounced in Shark River Slough, however, as Taylor Slough historically received more localized drainage from South Florida. Over the past 100 years, the original hydrologic landscape of the Everglades has undergone systematic drainage, compartmentalization, and diversion of freshwater resources (Light and Dineen 1994, Sklar et al. 2005, McVoy 2011). The diminished freshwater delivery to Everglades estuaries has resulted in increased salinities in the coastal zone and landward transgression of salt-tolerant vegetation communities (Ross et al. 2000, Gaiser et al. 2006). The Comprehensive Everglades Restoration Plan (CERP; www.evergladesplan.org) is an $\$ 8$ billion series of projects aimed at restoring Everglades hydrology to those that better approximate historical conditions. As a result of CERP restoration plans, Everglades estuaries will therefore experience an increase in freshwater delivery, but the effects of this change in hydrology on estuarine ecosystem function are not well understood. 


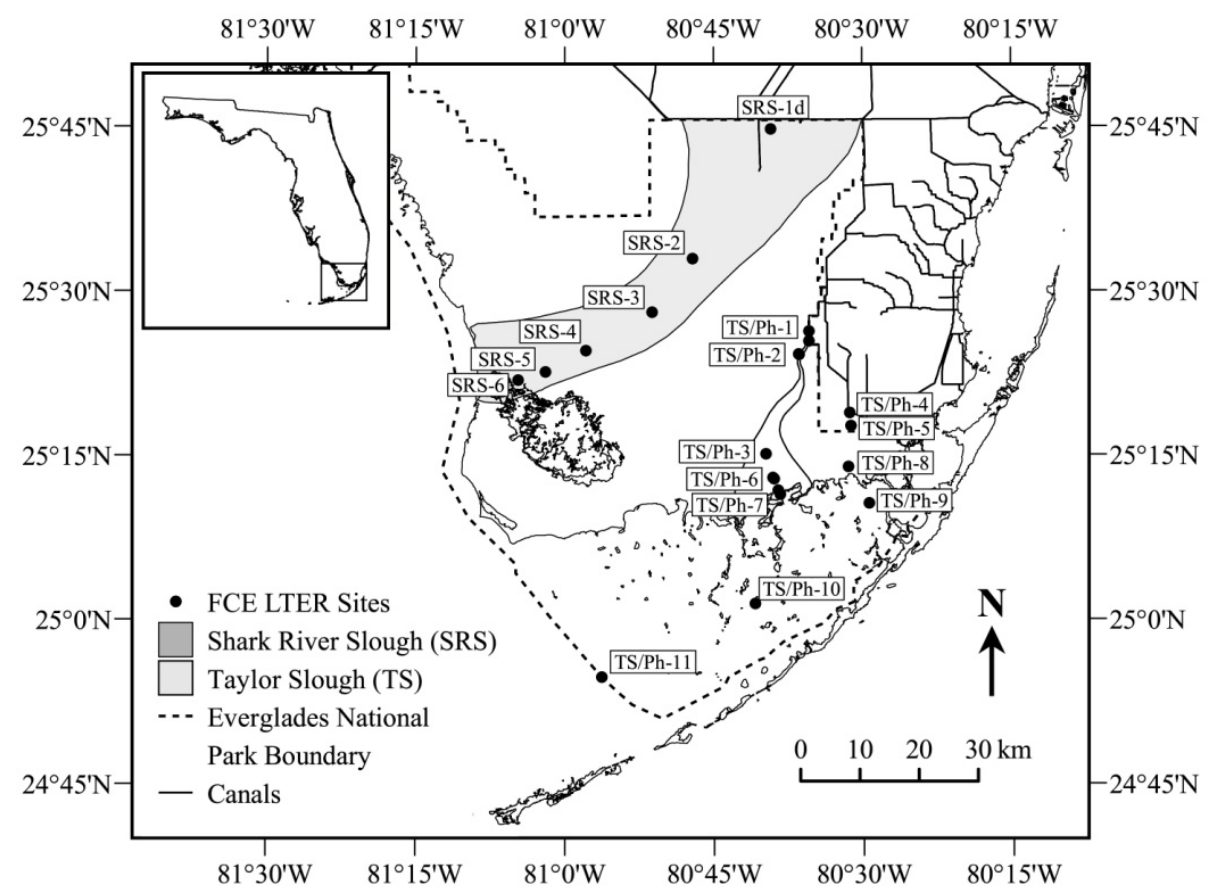

Figure 1. Map of Everglades National Park showing Shark River Slough and Taylor Slough, the two major drainage basins directing freshwater flows towards Everglades estuaries. Florida Coastal Everglades LongTerm Ecological Research (FCE LTER) sites are also shown as black dots.

Everglades estuaries, as well as the Greater Everglades landscape in general, are extremely oligotrophic, phosphorus (P)-limited, and very sensitive to changes in $\mathrm{P}$ availability (Boyer et al. 1999, Noe et al. 2001, Gaiser et al. 2004). A negligible amount of limiting $\mathrm{P}$ is supplied to downstream estuaries by the freshwater end-member of Everglades estuaries such that the dominant supply of $\mathrm{P}$ to these ecosystems is by the marine end-member (Chen and Twilley 1999), which is biogeochemically "upside-down" from traditional estuarine conditions (Childers et al. 2006). Results from Florida Coastal Everglades Long-Term Ecological Research (FCE LTER) led to two central hypotheses regarding restoration of Everglades hydrology and estuarine ecosystem function from which this dissertation is built and to which it directly contributes. First, increasing inputs of freshwater to Everglades estuaries will enhance oligotrophy in these nutrientpoor coastal systems, as long as the inflowing water has low nutrient content. Second, an 
increase in freshwater inflow will increase the physical transport of detrital organic matter to Everglades estuaries, which will enhance estuarine productivity. These hypotheses are potentially contradictory as detritus inputs may bolster estuarine primary production via nutrients remineralized detrital organic matter $(\mathrm{OM})$. On the other hand, detrital OM may instead fuel estuarine secondary productivity as Everglades food webs appear to be detritus-based (Williams and Trexler 2006, Belicka et al. 2012).

In this dissertation research, I used existing wet/dry subtropical seasonality to investigate relationships between hydrological and ecological variables, organized around the central theme: how will increased delivery of freshwater to Taylor River, an estuary in the southern Everglades, affect aquatic ecosystem function? The specific research questions that I addressed with this research were: 1) How do seasonal changes in surface water hydrology (velocity, depth) control the transport of flocculent detrital material?; and, 2) How does Taylor River hydrology control aquatic metabolism by regulating the supply of P and detrital inputs? Within Chapter II, I examine relationships between Taylor River water quantity, water quality, and aquatic ecosystem metabolism. Chapter III is an investigation of the properties of flocculent detritus in the Everglades landscape as well as an analysis of sampling methods thereof. Finally, Chapter IV is a study of seasonal dynamics of detrital transport in estuarine Taylor River. Together, these chapters illustrate how seasonal delivery of freshwater to Taylor River regulate the transport and storage of particulate $\mathrm{OM}$ as well as regulate the availability of limiting $\mathrm{P}$. These factors interact to regulate seasonal variation in whole ecosystem metabolism. 


\section{References}

Belicka, L.L., E.R. Sokol, J.M. Hoch, R. Jaffe, and J.C. Trexler. 2012. A molecular and stable isotope approach to investigate algal and detrital energy pathways in a freshwater marsh. Wetlands 32(3): 531-542.

Boyer, J. N., J. W. Fourqurean, and R. D. Jones. 1999. Seasonal and long-term trends in the water quality of Florida Bay (1989-1997). Estuaries 22: 417-430.

Chen, R. and R.R. Twilley. 1999. Patterns of mangrove forest structure and soil nutrient dynamics along the Shark River estuary, Florida. Estuaries 22(4): 955-970.

Childers, D. L., J. W. Day Jr., and H. N. McKellar Jr. 2000. Twenty more years of marsh and estuarine flux studies: Revisiting Nixon (1980). In: [M.P. Weinstein and D.Q. Kreeger, eds.] Concepts and Controversies in Tidal Marsh Ecology, pp. 391-423.

Childers, D.L. 2006. A synthesis of long-term research by the Florida Coastal Everglades LTER Program. Hydrobiologia 569(1):531-544.

Childers, D.L., J.N. Boyer, S.E. Davis, C.J. Madden, D.T. Rudnick, F.H. Sklar. 2006. Relating precipitation and water management to nutrient concentrations in the oligotrophic "upside-down" estuaries of the Florida Everglades. Limnology and Oceanography 51:602-616.

Correll, D.L. 1978. Estuarine productivity. BioScience 28(10): 646-650.

Gaiser, E. E., L. J. Scinto, J. H. Richards, K. Jayachandran, D. L. Childers, J. C. Trexler, and R. D. Jones. 2004. Phosphorus in periphyton mats provides the best metric for detecting low-level P enrichment in an oligotrophic wetland. Water Research 38: 507516.

Gaiser, E.E., A. Zafiris, P.L. Ruiz, F.A.C. Tobias, M.S. Ross. 2006. Tracking rates of ecotone migration due to salt-water encroachment using fossil mollusks in coastal South Florida. Hydrobiologia 569: 237-257.

Hobbie, J.E. (ed.) 2000. Estuarine science: the key to progress in coastal ecological research. In: Estuarine Science: A Synthetic Approach to Research and Practice, pp. 111, Island Press, Washington, DC.

Howarth, R.W., A. Sharpley, and D. Walker. 2002. Sources of nutrient pollution to coastal waters in the United States: implications for achieving coastal water quality goals. Estuaries 25(4b): 656-676. 
Light, S. S. and J. W. Dineen. 1994. Water control in the Everglades: a historical perspective. In: [S.M. Davis and J.C. Ogden, eds.] Everglades: The Ecosystem and its Restoration. St. Lucie Press, Delray Beach, FL.

McClain M.E., E.W. Boyer, C.L. Dent, S.E. Gergel, N.B. Grimm, P.M. Groffman, S.C. Hart, J.W. Harvey, C.A. Johnston, E. Mayorga, W.H. McDowell, G. Pinay. 2003. Biogeochemical hot spots and hot moments at the interface of terrestrial and aquatic ecosystems. Ecosystems 6: 301-312.

McVoy C. W. 2011. Landscapes and hydrology of the predrainage Everglades. University Press of Florida, Gainesville.

Milliman, J.D. and J.P.M. Syvitski. 1992. Geomorphic tectonic control of sediment discharge to the ocean - the importance of small mountainous rivers. Journal of Geology 100: 525-554.

Nixon, S. W. 1980. Between coastal marshes and coastal waters - a review of twenty years of speculation and research on the role of salt marshes in estuarine productivity and water chemistry. In: Estuarine and wetland processes with emphasis on modeling, Plenum Publishing, NY. p 437-525.

Nixon, S.W. C.A. Oviatt, J. Frithsen, and B. Sullivan. 1986. Nutrients and the productivity of estuarine and coastal marine ecosystems. Journal of the Limnological Society of Southern Africa 12: 43-71.

Noe, G.B., D.L. Childers, R.D. Jones. 2001. Phosphorus biogeochemistry and the impact of phosphorus enrichment: why is the Everglades so unique? Ecosystems 4: 603-624.

Odum, E. P. 1968. A research challenge: evaluating the productivity of coastal and estuarine water. In: Keiffner, E. (ed.) Proceedings of the Second Sea Grant Conference, Univ. of Rhode Island, Newport, Rhode Island, p 63-64.

Odum E.P. 1980. The status of three ecosystem-level hypotheses regarding salt marsh estuaries: tidal subsidy, outwelling, and detritus-based food chains. In: Estuarine Perspectives, Academic Press, NY. p 485-495.

Odum W.E., J.S. Fisher, J.C. Pickral. 1979. Factors controlling the flux of particulate organic carbon from estuarine wetlands. In: Ecological processes in coastal and marine systems. Plenum Press, London. p 69-82.

Ross, M.S., J.F. Meeder, J.P. Sah, P.L. Ruiz, and G.J. Telesnicki. 2000. The Southeast saline Everglades revisited: 50 years of coastal vegetation change. Journal of Vegetation Science 11: 101-112. 
Sklar, F.H., M.J. Chimney, S. Newman, P. McCormick, D. Gawlik, S. Miao, C. McVoy, W. Said, J. Newman, C. Coronado, G. Crozier, M. Korvela, and K. Rutchey. 2005. The ecological-societal underpinnings of Everglades restoration. Frontiers in Ecology and the Environment 3: 161-169.

Smith, S.V., and J.T. Hollibaugh. 1993. Coastal metabolism and the oceanic organic carbon balance. Reviews of Geophysics 31(1) 75-89.

Williams, A.J. and J.C. Trexler. 2006. A preliminary analysis of the correlation of foodweb characteristics with hydrology and nutrient gradients in the southern Everglades. Hydrobiologia 569: 493-504. 
II. Hydrological conditions control P loading and aquatic metabolism in an oligotrophic, subtropical estuary

Introduction

Estuaries and estuarine wetlands are ecologically and societally important systems, exhibiting high rates of primary production that fuel offshore secondary production (Odum 1968, Nixon 1980, Childers et al. 2000). Because they integrate entire upstream watersheds, estuarine ecosystems are recipients of nutrients and sediments from terrestrial sources (Milliman and Syvitski 1992, Smith and Hollibaugh 1993, Hobbie 2000, Howarth et al. 2002). Childers et al. (2006) suggested that, because of this loading, oligotrophic estuaries may be especially important as reference sites for investigating the effects of eutrophication in the coastal environment. Furthermore, hydrological processes play a central role in shaping estuarine ecosystem structure and function by controlling nutrient loading and the relative contributions of marine and terrestrial influences on the estuary. In this study I used high-resolution measures of aquatic ecosystem metabolism from an oligotrophic estuary in the Florida Everglades to assess how hydrological conditions control water quality and aquatic ecosystem dynamics by regulating nutrient availability.

The Florida Coastal Everglades Long-Term Ecological Research Program (FCE

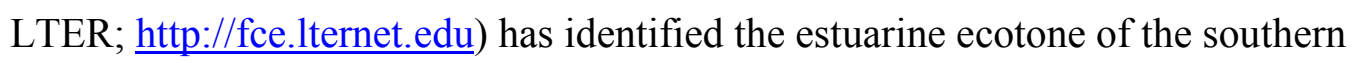
Everglades as a focal point of research because this shallow, topographically flat freshwater-estuarine interface is strongly influenced by seasonal changes in water source and flow (Childers et al. 2006). In the southern Everglades, primary productivity is 
greatest in the oligohaline ecotone (Ewe et al. 2006), a transition zone between freshwater sawgrass (Cladium jamaicense) marsh and red mangrove- (Rhizophora mangle) dominated scrub forest. Childers (2006) proposed that these relatively higher rates of primary production in the ecotone are supported by dry season increases in the limiting nutrient—phosphorus $(\mathrm{P})$ — that is regulated by the seasonal flushing of freshwater through the system (Childers et al. 2006; Fig. 1). High water column total phosphorus (TP) in the ecotone during the dry season may be derived from a number of sources. Price et al. (2006) show evidence for the discharge of high-P groundwater in the coastal Everglades, while Davis and Childers (2007) indicate internal recycling of P through biotic pathways. In addition, Caraco et al. (1989) demonstrate the potential for abiotic release of $\mathrm{P}$ from estuarine sediments. The focus of the FCE LTER program has largely been on wetland processes rather than on open water aquatic processes. Here, I examine the hypothesis of Childers (2006) from an aquatic perspective within the context of the ecotone ecosystem. 
A.

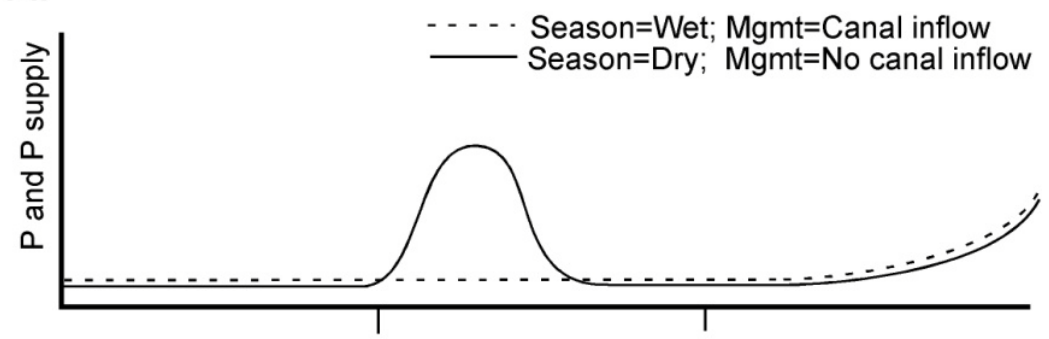

B.

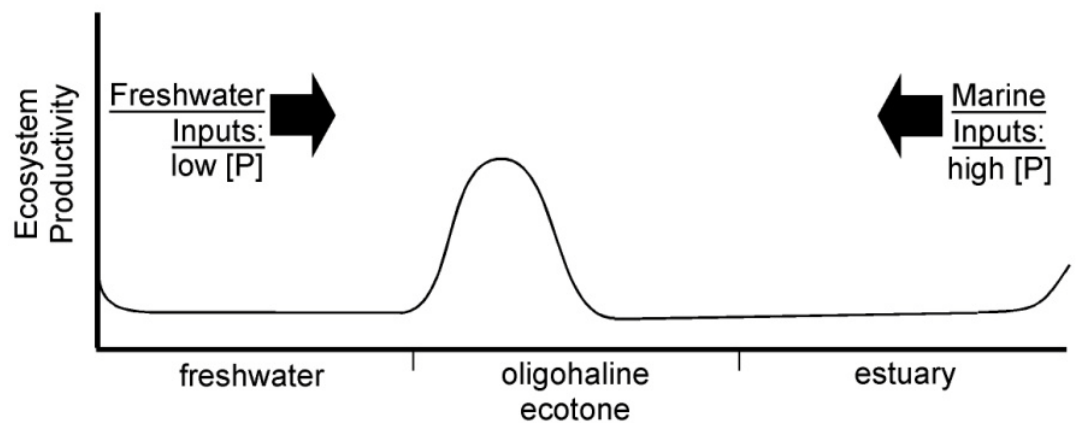

Figure 1. Conceptual model illustrating the change in P supply and ecosystem productivity across the Southern Everglades landscape.

The hydrologic conditions of the Everglades have undergone extensive compartmentalization over the last 100 years that has reduced freshwater flows to the estuaries (Light and Dineen 1994, Sklar et al. 2005). This diminished freshwater delivery to downstream estuaries has resulted in increased salinities in the coastal zone and landward transgression of salt-tolerant vegetation communities (Ross et al. 2000, Gaiser et al. 2006). The Comprehensive Everglades Restoration Plan (CERP; www.evergladesplan.org) aims to restore freshwater delivery to Everglades wetlands, ultimately resulting in increased freshwater flow to Everglades estuaries. With successful restoration, the southern Everglades mangrove ecotone should ultimately experience increased flow of freshwater that more closely approximates historical levels. Thus, it is important to understand how Everglades estuaries interact with freshwater inputs in order to guide restoration efforts. 
The extreme seasonal and interannual variability in water flow and source in my system affords the opportunity to examine the sensitivity of ecosystem metabolic processes to hydrologic forcing and variable supplies of the limiting nutrient, $\mathrm{P}$. Ecosystem metabolism includes whole system photosynthesis and respiration. Ecosystems with positive net ecosystem production (NEP, or gross primary production $[\mathrm{GPP}]>$ ecosystem respiration $[\mathrm{R}])$ are net autotrophic and produce excess organic matter, whereas those exhibiting negative NEP $(\mathrm{GPP}<\mathrm{R})$ are net heterotrophic and ultimately depend on allochthonous sources of organic carbon (Odum 1956, Dollar et al. 1991, Smith et al. 1991, Duarte and Prairie 2005). In this study, I investigated the FCE LTER hypotheses regarding P supply and ecosystem productivity as presented in Childers (2006). Specifically, I characterized long-term variation in southern Everglades estuarine water quality as well as spatiotemporal variation of aquatic, whole-ecosystem metabolism. I then evaluated the contribution of seasonally changing water quality drivers to variation in aquatic ecosystem metabolism rates. I hypothesized that ecosystem GPP and R would be greatest during the dry, euhaline estuarine season coinciding with increased availability of water column P. I further expected to find net heterotrophy $(\mathrm{NEP}<0)$ throughout the year, sustained by low productivity and high inputs of allochthonous carbon.

Methods

Site Description

Taylor Slough is one of two major drainage basins within Everglades National Park, Florida, USA (Fig 2). Historically water entered this watershed largely via local 
precipitation, but the water budget now includes managed canal inputs (Light and Dineen 1994, Childers et al. 2006). Taylor River (the estuarine portion of Taylor Slough) is one of the most important hydrologic connections between Taylor Slough freshwater marshes and northeastern Florida Bay (Davis et al. 2001, Sutula et al. 2003) and is characterized by a series of connected ponds and creeks meandering through extensive scrub mangrove wetlands. I estimated ecosystem metabolism in three centrally-located Taylor River ponds: Pond $3\left(4.69 \mathrm{ha}, 25.2035^{\circ} \mathrm{N}, 80.6437^{\circ} \mathrm{W}\right)$, Pond $4\left(0.66 \mathrm{ha}, 25.2057^{\circ} \mathrm{N}\right.$, $\left.80.6464^{\circ} \mathrm{W}\right)$, and Pond $5\left(0.60 \mathrm{ha}, 25.2075^{\circ} \mathrm{N}, 80.6453^{\circ} \mathrm{W}\right.$; Fig. 2). These ecosystems, as with the Greater Everglades landscape in general, are P-limited, oligotrophic, and very sensitive to changes in P availability (Boyer et al. 1999, Noe et al. 2001, Gaiser et al. 2004). In addition, South Florida's climate is subtropical and marked by a wet season from June through November and a dry season from December through May (Duever et al. 1994). This estuarine system experiences minimal astronomical tide and has minimal topographic relief. The ecotone is a mangrove-dominated basin separated from Florida Bay by the Buttonwood Ridge, a higher elevation coastal berm. Surface water exchange between Taylor River and Florida Bay occurs where the river incises the ridge. Freshwater flows down Taylor River and into Florida Bay during the wet season, while wind-forced excursions of high-salinity Florida Bay water move upriver during the dry season. Surface water in Taylor River is in direct hydraulic connection with groundwater in the underlying Biscayne Aquifer. The Biscayne Aquifer is a karstic, carbonate aquifer, and one of the most permeable aquifers in the world (Fish and Stewart, 1991). In the mangrove ecotone region of Taylor River, up to two meters of peat deposits overly this carbonate aquifer. 


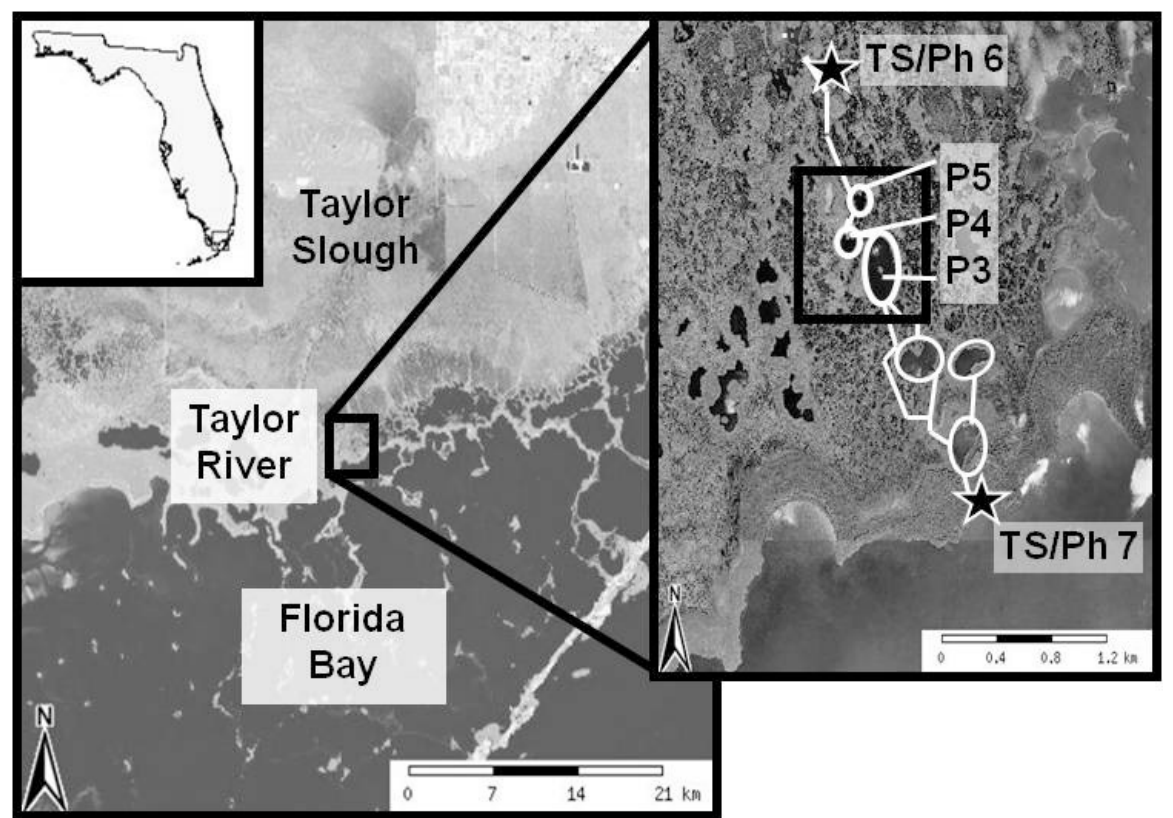

Figure 2. Satellite imagery showing the location of Taylor River (outlined in white) within the Taylor Slough watershed of Everglades National Park. This study was conducted in three ponds (from south to north: Pond 3, Pond 4, and Pond 5) midway between FCE LTER sites TS/Ph-6 (upstream) and TS/Ph-7 (downstream). Note the abundance of small ponds in the southern Everglades landscape.

\section{Long Term Hydrologic and Water Quality Variables}

Two water quality monitoring stations are located along the reach of Taylor River as part of the FCE LTER Program (TS/Ph 6 and TS/Ph 7) where water quality has been continuously monitored since 1996 (Fig 2). Here I investigate intra-annual variability in salinity and TP concentrations collected from 1996-2010 in Taylor River in order to relate these abiotic drivers to aquatic ecosystem metabolism estimates. Each FCE LTER station has an automated ISCO water sampler to collect samples from the middle of the water column. The data presented here are $1 \mathrm{~L}$ water samples integrated either daily (4 subsamples collected every 6 hours) or tri-daily (4 subsamples collected every 18 hours; see Childers et al. 2006 for details). Autosamplers were serviced monthly by FCE LTER staff, and unfiltered water samples were returned to the lab for TP and salinity analysis. TP concentrations were determined using the dry ashing/acid hydrolysis technique 
(Solorzano and Sharp 1980). Salinity was measured using either a refractometer or YSI salinometer (Childers et al. 2006). I also obtained Taylor River discharge data from U.S. Geologic Survey (USGS) gauging stations located near FCE LTER sites. These data are publically available through the USGS South Florida Information Access website (http://sofia.usgs.gov). Lastly, I obtained regional rainfall data from the Royal Palm Ranger Station located in northern Taylor Slough, Everglades National Park. These data are made available through the LTER Network and US Forest Service Climate and Hydrology Database Projects (http://www.fsl.orst.edu/climhy). To approximate salinity concentrations at my study sites, which were located in the middle reach of Taylor River between FCE LTER and USGS monitoring stations (Fig. 2), I used the arithmetic mean between upstream and downstream salinity measurements.

\section{Ecosystem Metabolism from Buoy Measurements}

I estimated daily gross primary production (GPP), ecosystem respiration (R), and net ecosystem production (NEP = GPP - R) of three ponds in the Taylor River system (Fig. 2) from November 2008 through May 2010. GPP, R, and NEP were determined from free-water, diel changes in dissolved oxygen (Odum 1956, Staehr et al. 2010a). At the center of each pond I deployed a buoy with sensors measuring dissolved oxygen, water temperature, wind speed, surface irradiance, and underwater PAR. Data were collected continuously at 10-minute intervals. Each buoy contained one OxyGuard ${ }^{\circledR} 525$ membrane dissolved oxygen sensor (OxyGuard International A/S, Denmark), three HOBO ${ }^{\circledR} \#$ UA-002-64 underwater temperature and PAR sensors, one $\mathrm{HOBO}{ }^{\circledR}$ \#S-LIAM003 surface PAR sensor, and one $\mathrm{HOBO}{ }^{\circledR}$ \#S-WSA-M003 anemometer attached to a 
HOBO ${ }^{\circledR} \#$ H21-002 micro-station datalogger (Onset Computer Corp., USA) housed within a waterproof case. The dissolved oxygen sensor was powered by a $12 \mathrm{~V}$ battery recharged by a solar panel. Buoys were visited monthly to perform sensor cleaning, maintenance, calibration, and data retrieval.

Oxygen concentrations were used to calculate daily volumetric rates $\left(\mathrm{mmol} \mathrm{O}_{2} \mathrm{~m}^{-}\right.$ ${ }^{3} \mathrm{~d}^{-1}$ ) of GPP, R, and NEP according to governing equation:

$$
\Delta \mathrm{O}_{2} / \Delta \mathrm{t}=\mathrm{GPP}-\mathrm{R}-\mathrm{F}
$$

where $\Delta \mathrm{O}_{2} / \Delta \mathrm{t}$ is the change in dissolved oxygen over a known period of time, GPP is gross primary production, $\mathrm{R}$ is respiration, and $\mathrm{F}$ is diffusive exchange of oxygen between the water column and the atmosphere (Odum 1956). I assumed that no GPP occurs during night and that nighttime $\mathrm{R}$ is equal to daytime R. For ease of comparison, I present GPP values as positive and R values as negative. Atmospheric diffusion (F) was modeled as:

$$
\mathrm{F}=k\left(\mathrm{O}_{2 \text { meas }}-\mathrm{O}_{2 \text { sat }}\right)
$$

where $\mathrm{k}$ is piston velocity, $\mathrm{O}_{2 \text { meas }}$ is the measured dissolved oxygen concentration, and $\mathrm{O}_{2 \text { sat }}$ is the oxygen saturation of the water corrected for both temperature and salinity (Staehr et al. 2010a). Piston velocity is defined as:

$$
k=k_{600} *(S c / 600)^{-0.5}
$$

where $k_{600}$ is $k$ for a Schmidt number of 600 and $S c$ is the Schmidt number for the time step (Jähne et al. 1987). $k_{600}$ was determined from wind speed at $10 \mathrm{~m}$ height above the water surface (Cole and Caraco 1998):

$$
k_{600}=2.07+0.215\left(\operatorname{wind}_{10 \mathrm{~m}}\right)^{1.7}
$$


However, since wind measurements are not typically taken at $10 \mathrm{~m}$ height, I modeled wind speed at 10m from wind speed at a known height according to Smith (1985):

$$
\operatorname{wind}_{10 \mathrm{~m}}=\operatorname{wind}_{\mathrm{z}}\left(1.4125\left(\mathrm{z}^{-0.15}\right)\right)
$$

where $\operatorname{wind}_{\mathrm{z}}$ is the wind speed measured at height z. Finally, I derived the Schmidt number $(S c)$, an indicator of gaseous molecular movement, for each time step from water temperature (Wanninkhof 1992):

$$
S c=0.0476(\mathrm{~T})^{3}+3.7818(\mathrm{~T})^{2}-120.1(\mathrm{~T})+1800.6
$$

where $\mathrm{T}$ is water temperature $\left({ }^{\circ} \mathrm{C}\right)$. For a detailed discussion of the calculations and assumptions used to estimate ecosystem metabolism via this method please refer to Staehr et al. (2010a).

Water Residence Time Estimation

I estimated water residence time (WRT) in estuarine ponds from 1999-2009 following the equation:

$$
\mathrm{WRT}=\mathrm{A}_{\mathrm{p}} * \mathrm{Z} /\left(\mathrm{Q}+\mathrm{ET} * \mathrm{~A}_{\mathrm{p}}\right)
$$

where $A_{p}$ is the surface area of the pond, $\mathrm{Z}$ is water depth, $\mathrm{Q}$ is surface water discharge, and ET is evapotranspiration. Pond area was estimated from aerial photography via Google Earth. Pond depth was determined from USGS stage data from site TS/Ph-6; however, USGS stage data are reported as relative to the North American Vertical Datum of 1988 (NAVD88). Since I did not know the elevation of the pond bed relative to NAVD88, I approximated water depth by assuming that the 10-year mean stage was equal to a 1-meter water depth. Thus, deviations from the overall stage mean corresponded to equal deviations from $1 \mathrm{~m}$ pond depth. I assumed that surface water 
discharge from the ponds was equal to discharge measured at TS/Ph-6. Finally, I used ET data at nearby Joe Bay obtained from the South Florida Water Management District (SFWMD) DBHydro database

(http://my.sfwmd.gov/dbhydroplsql/show_dbkey_info.main_menu). Although water loss to groundwater recharge likely occurred at certain times, Taylor River received water input from groundwater over the long term and this input is captured in TS/Ph-6 discharge rates (Zapata-Rios 2009). Lastly, I also obtained discharge data measured in freshwater Taylor Slough, made available by Everglades National Park, in order to compare managed inputs of freshwater to estimates of estuarine WRT.

\section{Groundwater Sampling}

Groundwater samples were collected monthly from June 2008 to June 2009 from 4 wells at TS/Ph-7 and 3 wells at TS/Ph-6. The wells were located along transects oriented perpendicular to the main river channel. The wells were constructed from 2.5 $\mathrm{cm}$ or $5 \mathrm{~cm}$ diameter PVC pipe and placed to depths of about $0.75 \mathrm{~m}$ at TS/Ph- 6 and 1.5 $\mathrm{m}$ at TS/Ph-7, corresponding with the depth of the peat/limestone interface. A complete description of well construction and locations can be found in Zapata-Rios (2009). Prior to sample collection, each well was purged of at least 3 well volumes of water using a peristaltic pump. During that time, specific conductance, salinity, temperature, $\mathrm{pH}$ and dissolved oxygen were monitored in the discharge water until stable readings were obtained using a YSI-85 meter. Samples were then collected into helium-purged and vacuum-sealed collection bags to preserve the anoxic state of the groundwater. I stored samples on ice for immediate transport to the Southeast Environmental Research Center 
nutrient laboratory at Florida International University for TP analysis according to Solorzano and Sharp (1980).

Statistical Analyses

I summarized Taylor River surface water hydrologic and nutrient variables by calculating arithmetic means for each month in the 1996-2010 FCE LTER dataset. In addition, I calculated an overall monthly mean across all sampled years (e.g., one mean for all January data, etc.). In order to reduce short-term noise and because the data used this study were collected at differing frequencies, all data were also summarized into weekly arithmetic means for statistical comparison. I tested all data for normality using Shapiro-Wilk tests. Differences between upstream vs. downstream stations and wet vs. dry seasons were then tested using either Student's t-tests on normally distributed data or Mann-Whitney rank sum tests on non-normal data. In order to test for significant seasonal differences in measured variables, I defined "wet" season as occurring when surface water salinities were at or near zero (September-February) and "dry" season as all other times (March-August). This is in contrast to the conventional wet/dry distinctions based on rainfall in South Florida (May-November $=$ wet season and December-April $=$ dry season; Duever et al. 1994). My adjusted seasonal demarcation is more closely linked to the timing of seasonal freshwater pulses through the estuary.

Relationships between metabolic, physical, and chemical variables were examined using Pearson's correlation analysis. I explored controls on the variation in estuarine metabolism rates using multiple regression analysis; however, time series data commonly violate regression assumptions about the independence of data points. After 
testing for the presence of autocorrelation within the time series using Durbin-Watson tests, I used an autoregressive model that accounts for autocorrelation (Proc Autoreg using SAS 9.2, SAS Institute Inc., USA). The autoregressive model is nearly identical to ordinary multiple regression models except that significant relationships between previous data points within the time series may be included as parameters in the model. Thus, variation is explained that would otherwise be attributed to model error and the model gains predictive power. Correcting for autocorrelation in regression models has been used in the statistics and economics fields for decades (e.g., Durbin 1960, Beach and MacKinnon 1978), but has gained increasing use in ecological studies in recent years (e.g., Carpenter et al. 1998, Lichstein et al. 2002, Staehr et al. 2010b). I used a backwards stepwise autoregressive model to identify and include only significant orders of autocorrelation. It should be noted that in this procedure "stepwise" refers to the elimination of insignificant orders of autocorrelation in the model and not to the elimination of insignificant model predictors. I initially included a suite of independent predictor variables in the regression model based on the results of the correlation analysis. I then iteratively removed insignificant predictors one at a time and the model with the lowest corrected Akaike's Information Criterion (AICc; Burnham and Anderson 2002) was selected. Occasionally, removal of an insignificant predictor variable caused deterioration in model AICc. In these cases, I chose to include the insignificant predictor if it did not show antagonistic effects with the other predictors in the model. Model parameters were determined using maximum likelihood estimation. Both correlation and regression analyses were performed on weekly means of variables for each pond as well 
as for a combined mean across all ponds. I used $\alpha=0.05$ to determine significance for all statistical tests in this study.

Results

\section{Long Term Water Quality Patterns}

Taylor River discharge rates exhibited temporal variability closely matching variation in rainfall with exceptionally wet years having elevated rates of discharge and exceptionally dry years have depressed rates of discharge (e.g, 1999 vs. 2004, Fig. 3a). Discharge at the upstream $\mathrm{TS} / \mathrm{Ph} 6$ site ranged from -0.3 to $0.8 \mathrm{~m}^{3} / \mathrm{s}$, with a 14 -year mean of $0.3 \mathrm{~m}^{3} / \mathrm{s}$. At the downstream TS/Ph 7 site, discharge ranged from -0.7 to $5.5 \mathrm{~m}^{3} / \mathrm{s}$ and averaged $1.1 \mathrm{~m}^{3} / \mathrm{s}$. Discharge was significantly higher at the river mouth $(\mathrm{TS} / \mathrm{Ph}-7)$ than at the upstream gauge (TS/Ph-6; $p<0.0001)$ as downstream TS/Ph-7 integrated more of the mangrove wetland ecotone and was the only local cut through the Buttonwood Ridge. In addition, estuarine discharge rates showed a repeating, seasonal pattern with highest discharge rates occurring 1-2 months after peak regional rainfall (Fig. 3a). Examining intra-annual patterns in discharge using polar plots showed that highest discharge rates at both sites consistently occurred during September-February while lowest discharge rates at both monitoring sites occurred during May (Fig. 4a-b). 


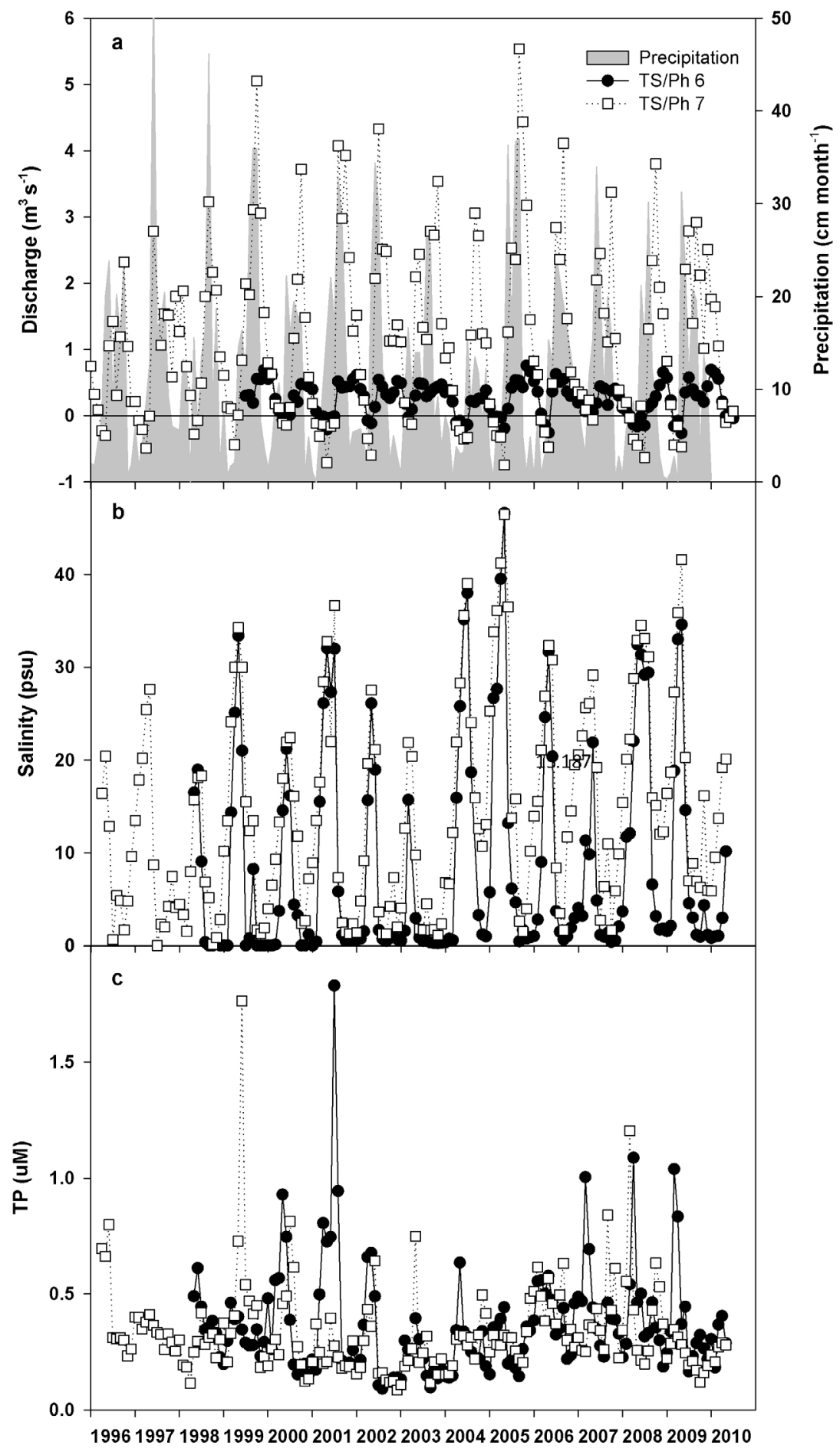

Figure 3. Monthly mean discharge $\left(\mathrm{m}^{3} \mathrm{~s}^{-1}\right.$, panel a), salinity (psu, panel b), and TP $(\mu \mathrm{M}$, panel c) data from sites TS/Ph-6 (filled circles) and TS/Ph-7 (open squares). Monthly total precipitation data $(\mathrm{cm} /$ month, panel a) were measured at the Royal Palm station in Taylor Slough, north of Taylor River. 


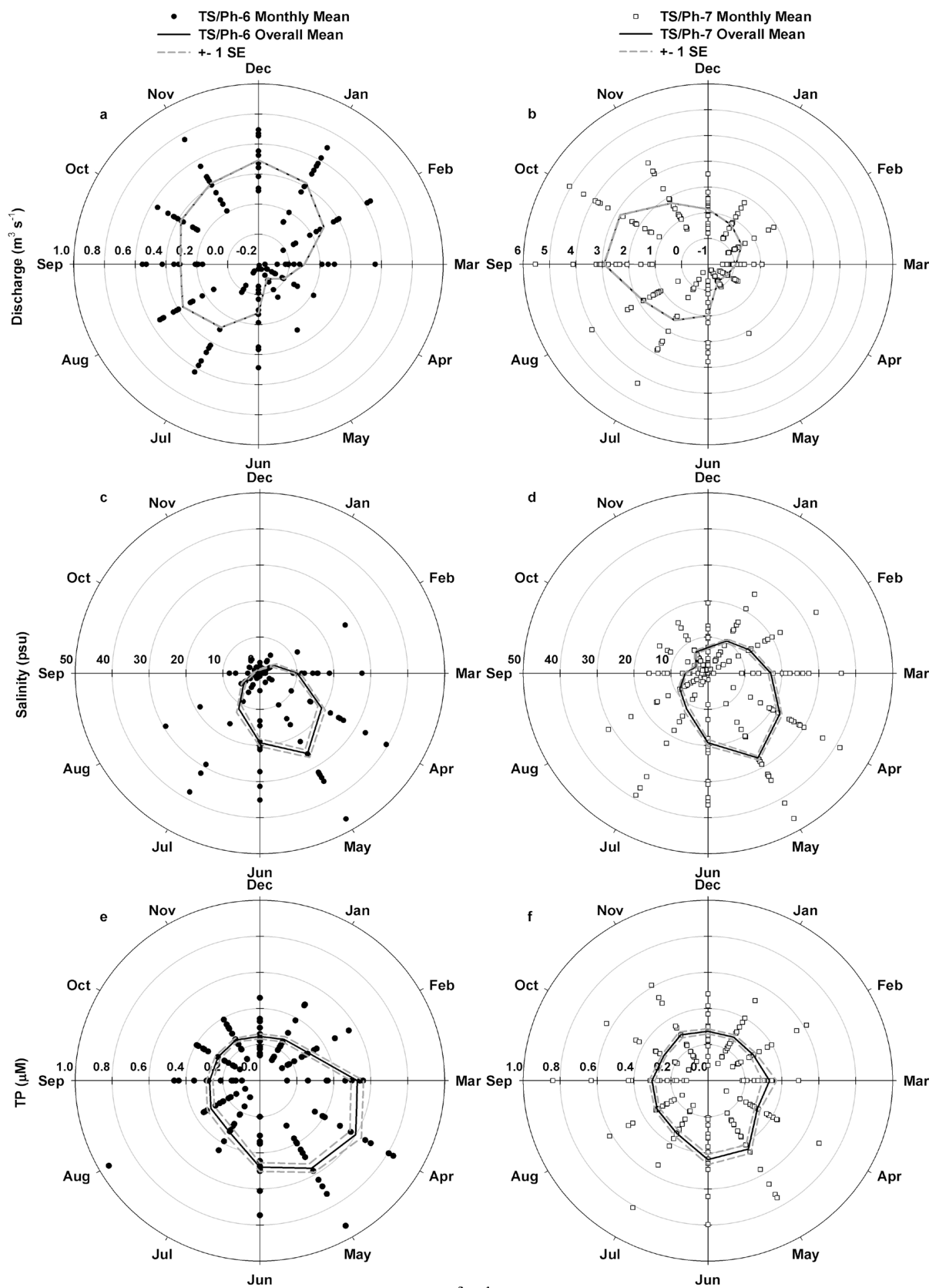

Figure 4. Polar plots of monthly mean discharge $\left(\mathrm{m}^{3} \mathrm{~s}^{-1}\right.$; panels a-b), salinity (psu; panels c-d), and TP ( $\mu$ mol L ${ }^{-1}$; panels e-f) data from sites TS/Ph-6 (filled circles, left column) and TS/Ph-7 (open squares, right column) for the years 1996-2010. The solid black line in all plots indicates an overall monthly mean for the data record with grey dashed lines indicating $\pm 1 \mathrm{SE}$ of the overall mean. Months progress clockwise around the plot. Magnitude of data points is represented by radial distance from the center of the plot. 
Interannual variability in salinity was similar to patterns in precipitation and discharge (Fig. 3b). Unlike discharge rates, however, both TS/Ph 6 and TS/Ph 7 exhibited similar magnitudes of change in salinity each year: salinity at TS/Ph 6 ranged from 0.0 to $46.6 \mathrm{PSU}$ with a mean of $8.7 \mathrm{PSU}$, while salinity at TS/Ph 7 ranged from 0.0 to 46.5 PSU with a mean of 14.2 PSU. Polar plot analysis revealed that highest salinity concentrations in Taylor River surface water occurred from March through August when discharge rates were lowest (Fig. 4c-d).

Total P concentrations were generally below $0.5 \mu \mathrm{M}$ although I did observe higher TP values at both sites during exceptionally dry years (Fig. 3c). Total P at the upstream TS/Ph 6 site ranged from $0.1-1.8 \mu \mathrm{M}$ with a mean of $0.4 \mu \mathrm{M}$ while TP at TS/Ph 7 ranged from $0.1-1.8 \mu \mathrm{M}$ with a mean of $0.3 \mu \mathrm{M}$. Median TP concentrations at the two sites were not significantly different; however, from the polar plots it is clear that TP at upstream TS/Ph 6 exhibited a larger seasonal range and variability than TP at downstream TS/Ph 7 (Fig. 4e-f). While mean water column TP was relatively consistent throughout the year at TS/Ph 7, TP was highest during the dry season at the TS/Ph 6 site.

Ecosystem Metabolism Dynamics

Aquatic ecosystem GPP in Taylor River showed a clear seasonal pattern during 2008-2010 (Fig. 5a). Gross primary production was highest during the nutrient rich 2009 dry season while the 2010 dry season showed a similar but smaller peak in ecosystem GPP. Furthermore, GPP was lowest during the 2009 wet season. Ecosystem R followed a temporal pattern similar to that of GPP (Fig. 5b), with a baseline rate of roughly 100$200 \mathrm{mmol} \mathrm{O}_{2} \mathrm{~m}^{-3} \mathrm{~d}^{-1}$. Respiration was much more variable during the 2010 dry season 
than during preceding periods of the study. I found sustained net heterotrophy (GPP $<$ R; NEP $<0$ ) in all three Taylor River ponds throughout the study period (Fig. 5c). There was a brief period of net autotrophy (GPP > R; NEP > 0) during January 2010 that coincided with the passage of a cold front across South Florida that reduced water temperature below $10^{\circ} \mathrm{C}$, with a minimum of $7.9^{\circ} \mathrm{C}$. The switch from heterotrophic to autotrophic conditions was related to a reduction in pond respiration (from 200 to 100 mmol $\mathrm{O}_{2} \mathrm{~m}^{-3} \mathrm{~d}^{-1}$ ) during a simultaneous period of enhanced GPP (from $>100$ to 200 $\mathrm{mmol} \mathrm{O} \mathrm{m}^{-3} \mathrm{~d}^{-1}$ ). 


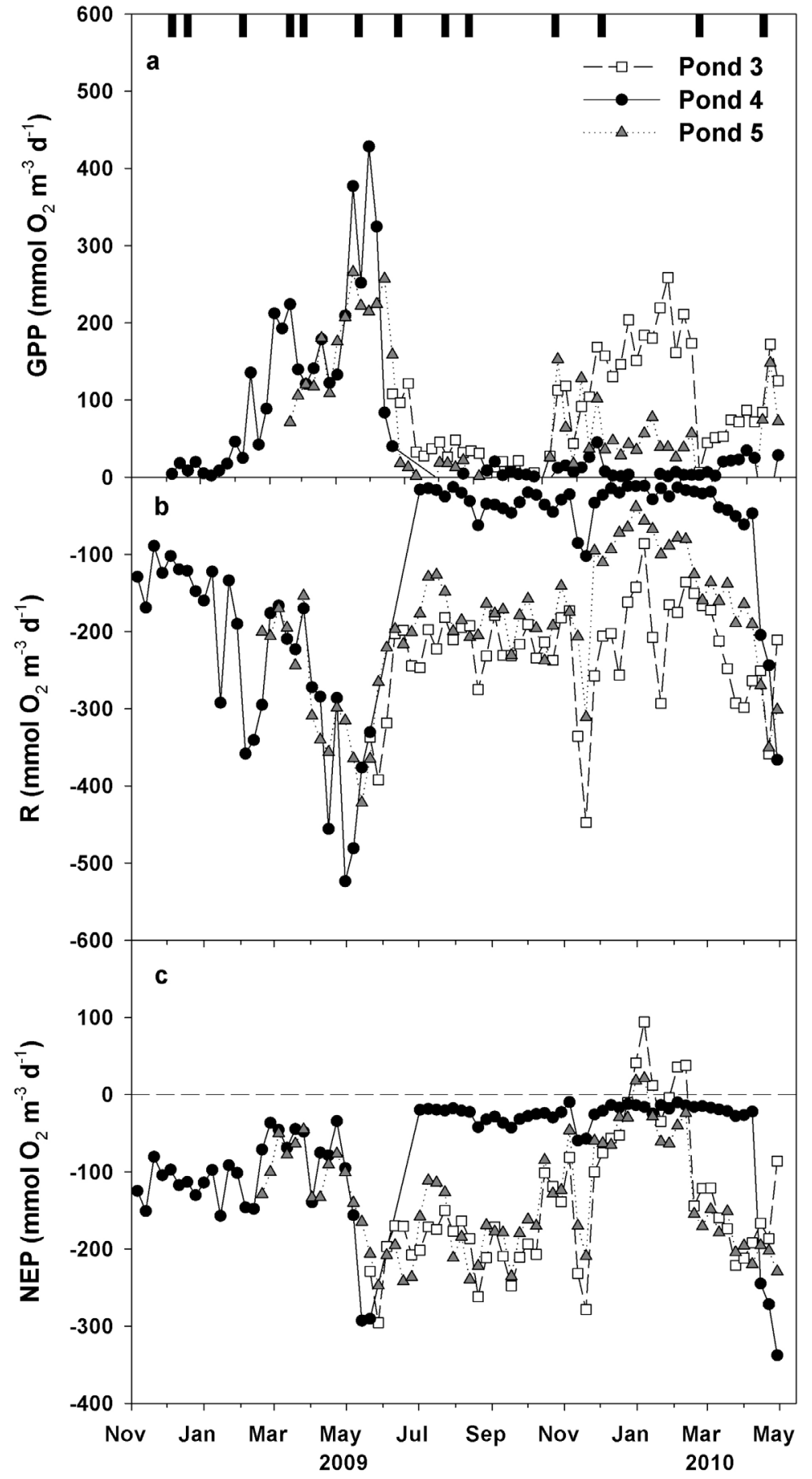

Figure 5. GPP (panel a), R (panel b), and NEP (panel c) from Taylor River ponds 3 (open squares), 4 (black circles), and 5 (gray triangles). Metabolism components are reported as weekly means of daily, volumetric rates $\left(\mathrm{mmol} \mathrm{O}_{2} \mathrm{~m}^{-3} \mathrm{~d}^{-1}\right)$. Black bars at the top of the figure indicate calibration dates. 
Patterns in whole system metabolism were surprisingly pond-specific (Table 1). Pond 3 and Pond 4 GPP was negatively correlated with surface irradiance $\left(\mathrm{I}_{0}\right)$ while Pond 5 GPP was positively correlated with $\mathrm{I}_{0}$. Salinity and TP concentration were positively correlated with GPP in Pond 4 and Pond 5 but not with GPP in Pond 3. Phosphorus flux estimates were negatively correlated with GPP in Pond 4 and Pond 5. Furthermore, watershed P retention was positively correlated to GPP in Pond 5 but not correlated to GPP in Pond 3 or Pond 4. Combined average pond GPP was positively correlated with $\mathrm{I}_{0}$, salinity, upstream [TP], and P retention, while negatively correlated to both upstream and downstream P fluxes. Ecosystem R was positively correlated with GPP in Pond 4 and Pond 5 but not correlated with GPP in Pond 3. Respiration was also positively correlated with salinity and upstream [TP] across all ponds as well as with temperature and downstream [TP] in Pond 3 and Pond 5. Respiration was negatively correlated with both upstream and downstream P fluxes in Pond 4 and Pond 5, but positively correlated with $\mathrm{P}$ retention in Pond 5. When the ponds were combined, $\mathrm{R}$ was positively correlated with GPP, $\mathrm{I}_{0}$, temperature, salinity, upstream [TP], and P retention while negatively correlated with $\mathrm{P}$ fluxes from both upstream and downstream. Net ecosystem production was positively correlated with GPP in Ponds 3 and 5 and negatively correlated with R in all ponds. Net ecosystem production was negatively correlated with salinity in Ponds 3 and 4. In addition, NEP was negatively correlated with both $\mathrm{I}_{0}$ and temperature in Pond 3 and Pond 5. In addition, NEP was negatively correlated with upstream [TP] only in Pond 3. Combined NEP was negatively correlated to R, $\mathrm{I}_{0}$, salinity, and temperature. 
Table 1. Pairwise Pearson correlation coefficients between metabolism rates $(G P P, R, N E P)$ and environmental driving variables: $I_{0}=$ surface irradiance, Temp $=$ water temperature at $50 \mathrm{~cm}$ depth, Wind $=$ wind speed at $10 \mathrm{~m}$ above the water surface, salinity, TP concentration measured at upstream TS/Ph- 6 and downstream TS/Ph-7, upstream and downstream flux of $\mathrm{P}$, and P retention (upstream flux - downstream flux). Correlation analyses were performed using weekly means of variables.

\begin{tabular}{|c|c|c|c|c|c|c|c|c|c|c|c|c|}
\hline & & $\mathrm{I}_{0}$ & Temp & Wind & Salinity & $\begin{array}{c}\text { TS6 } \\
{[\mathrm{TP}]}\end{array}$ & $\begin{array}{c}\text { TS7 } \\
{[\mathrm{TP}]}\end{array}$ & $\begin{array}{c}\text { TS6 } \\
\text { P Flux }\end{array}$ & $\begin{array}{c}\text { TS7 } \\
\text { P Flux }\end{array}$ & $P_{\text {Ret }}$ & $\mathrm{R}$ & NEP \\
\hline $\begin{array}{l}\text { Pond } 3 \\
(\mathrm{n}=51)\end{array}$ & $\begin{array}{c}\text { GPP } \\
\text { R } \\
\text { NEP }\end{array}$ & $\begin{array}{l}-0.60^{* * *} \\
0.17 \\
-0.58^{* * *}\end{array}$ & $\begin{array}{l}-0.60^{* * *} \\
0.40^{* *} \\
-0.75^{\text {*** }}\end{array}$ & $\begin{array}{c}0.27 \\
-0.07 \\
0.31^{*}\end{array}$ & $\begin{array}{c}0.04 \\
0.57^{* * *} \\
-0.40^{* *}\end{array}$ & $\begin{array}{l}0.09 \\
0.51^{* * *} \\
-0.32^{*}\end{array}$ & $\begin{array}{r}0.07 \\
0.17 \\
-0.08\end{array}$ & $\begin{array}{r}0.14 \\
-0.06 \\
0.16\end{array}$ & $\begin{array}{c}-0.10 \\
-0.25 \\
0.11\end{array}$ & $\begin{array}{r}0.16 \\
0.26 \\
-0.07\end{array}$ & $\begin{array}{l}0.11 \\
--\end{array}$ & $\begin{array}{l}0.68^{\text {**** }} \\
-0.66^{\text {*** }} \\
--\end{array}$ \\
\hline $\begin{array}{l}\text { Pond } 4 \\
(\mathrm{n}=75)\end{array}$ & $\begin{array}{c}\text { GPP } \\
\text { R } \\
\text { NEP }\end{array}$ & $\begin{array}{l}-0.44^{* * *} \\
0.42^{* * *} \\
0.18\end{array}$ & $\begin{array}{r}0.05 \\
0.10 \\
-0.11\end{array}$ & $\begin{array}{l}0.38^{* * *} \\
0.43^{* * *} \\
-0.18\end{array}$ & $\begin{array}{l}0.75^{* * *} \\
0.82^{* * *} \\
-0.50^{\text {*** }}\end{array}$ & $\begin{array}{l}0.65^{* * *} \\
0.44^{* * *} \\
-0.00\end{array}$ & $\begin{array}{c}0.21 \\
0.27^{*} \\
-0.20\end{array}$ & $\begin{array}{c}-0.45^{* * *} \\
-0.42^{* *} \\
0.18\end{array}$ & $\begin{array}{c}-0.34^{*} \\
-0.36^{*} \\
0.19\end{array}$ & $\begin{array}{l}0.20 \\
0.19 \\
0.53\end{array}$ & $0.82^{* * *}$ & $\begin{array}{l}-0.19 \\
-0.72^{\text {**** }} \\
--\end{array}$ \\
\hline $\begin{array}{l}\text { Pond } 5 \\
(\mathrm{n}=65)\end{array}$ & $\begin{array}{c}\text { GPP } \\
\text { R } \\
\text { NEP }\end{array}$ & $\begin{array}{c}0.31^{*} \\
0.64^{* * *} \\
-0.47^{* * *}\end{array}$ & $\begin{array}{l}-0.03 \\
0.51^{* * *} \\
-0.66^{* * *}\end{array}$ & $\begin{array}{l}0.42^{* * *} \\
0.27^{*} \\
0.13\end{array}$ & $\begin{array}{l}0.78^{* * *} \\
0.78^{* * *} \\
-0.08\end{array}$ & $\begin{array}{l}0.57^{* * *} \\
0.38^{*} \\
0.14\end{array}$ & $\begin{array}{c}0.28^{*} \\
0.28^{*} \\
-0.03\end{array}$ & $\begin{array}{l}-0.57^{* * *} \\
-0.33^{* *} \\
-0.19\end{array}$ & $\begin{array}{l}-0.59^{* * *} \\
-0.48^{* * *} \\
-0.07\end{array}$ & $\begin{array}{l}0.30^{*} \\
0.27^{*} \\
0.00\end{array}$ & $0.63^{* * *}$ & $\begin{array}{l}0.32^{*} \\
-0.53^{\text {*** }} \\
--\end{array}$ \\
\hline $\begin{array}{c}\text { Combined } \\
(\mathrm{n}=75)\end{array}$ & $\begin{array}{c}\text { GPP } \\
\text { R } \\
\text { NEP }\end{array}$ & $\begin{array}{c}0.32^{* *} \\
0.55^{* * *} \\
-0.41^{* * *}\end{array}$ & $\begin{array}{l}-0.08^{* *} \\
0.37^{* * *} \\
-0.62^{* *}\end{array}$ & $\begin{array}{l}0.45^{* * *} \\
0.32^{* *} \\
0.08\end{array}$ & $\begin{array}{c}0.74^{* * *} \\
0.83^{* * *} \\
-0.30^{* *}\end{array}$ & $\begin{array}{l}0.57^{\text {*** }} \\
0.44^{\text {*** }} \\
0.05\end{array}$ & $\begin{array}{r}0.11 \\
0.12 \\
-0.04\end{array}$ & $\begin{array}{l}-0.43^{* * *} \\
-0.30^{* *} \\
-0.08\end{array}$ & $\begin{array}{l}-0.41^{* * *} \\
-0.38^{* * *} \\
0.05\end{array}$ & $\begin{array}{c}0.27^{*} \\
0.25^{*} \\
-0.02\end{array}$ & $\begin{array}{l}0.71^{* * *} \\
--\end{array}$ & $\begin{array}{l}0.16 \\
-0.58^{\text {*** }} \\
--\end{array}$ \\
\hline
\end{tabular}

$* \mathrm{p}<0.05$
$* * \mathrm{p}<0.01$
$* * * \mathrm{p}<0.001$


The ability of environmental driver variables to predict variation in metabolism rates was also pond-specific (Table 2). In Pond 3, GPP was best predicted using both $\mathrm{I}_{0}$ and salinity; however, $\mathrm{I}_{0}$ was the only significant contributor to GPP variation. In contrast, Pond 4 GPP was best predicted from upstream (TS/Ph-6) TP concentration, with salinity and upstream TP Flux included as insignificant predictors. Salinity and water temperature were significant predictors of Pond 5 GPP although upstream [TP] was also included. Salinity and temperature best explained variation in GPP combined across all ponds. Models of ecosystem R always included GPP as a significant predictor at all ponds. In Pond 3, R was best explained by temperature, GPP, upstream [TP], salinity, and downstream [TP]. The best Pond $4 \mathrm{R}$ model included GPP, salinity, and upstream [TP]. In Pond 5, R was best modeled as a function of salinity, GPP, temperature, upstream P flux, and upstream [TP]. Regression analysis on combined R data revealed that GPP, temperature, salinity, upstream P flux and upstream [TP] were the best predictors of $\mathrm{R}$ across all ponds. NEP was best predicted by temperature and upstream [TP] in Pond 3, while the best model of Pond 4 NEP included salinity, upstream [TP], and $\mathrm{I}_{0}$. Pond $5 \mathrm{NEP}$ was best predicted by temperature, upstream P flux, salinity, and upstream [TP]. Finally, NEP combined across all ponds was best predicted by temperature, salinity, upstream P flux, and upstream [TP]. 
Table 2. Results of multiple autoregression analysis of environmental driver contributions to variability in estuarine metabolism rates. Analysis was performed on weekly means of variables: $n=$ number of weeks in the dataset, Temp $=$ water temperature at $50 \mathrm{~cm}$ depth $\left({ }^{\circ} \mathrm{C}\right), \mathrm{I}_{0}=$ surface irradiance $\left(\mu \mathrm{E} \mathrm{m}^{-2} \mathrm{~s}^{-1}\right)$, TP $6=$ water column total phosphorus concentration at site TS/Ph-6 $(\mu \mathrm{M})$, TP $7=$ water column total phosphorus at TS/Ph-7 $(\mu \mathrm{M})$, P Flux $6=$ upstream phosphorus flux $\left(\mu \mathrm{mol} \mathrm{s}^{-1}\right)$, P Flux $7=$ downstream phosphorus flux $\left(\mu \mathrm{mol} \mathrm{s} \mathrm{s}^{-1}\right), \mathrm{P}$ Ret $=$ watershed phosphorus retention $\left(\mu \mathrm{mol} \mathrm{s} \mathrm{s}^{-1}\right), \beta_{0}=$ intercept of the model, $\mathrm{r}_{\text {tot }}^{2}=$ total $\mathrm{r}^{2}$ statistic of the multiple autoregression model. Bold text indicates significance at $\alpha=0.05$.

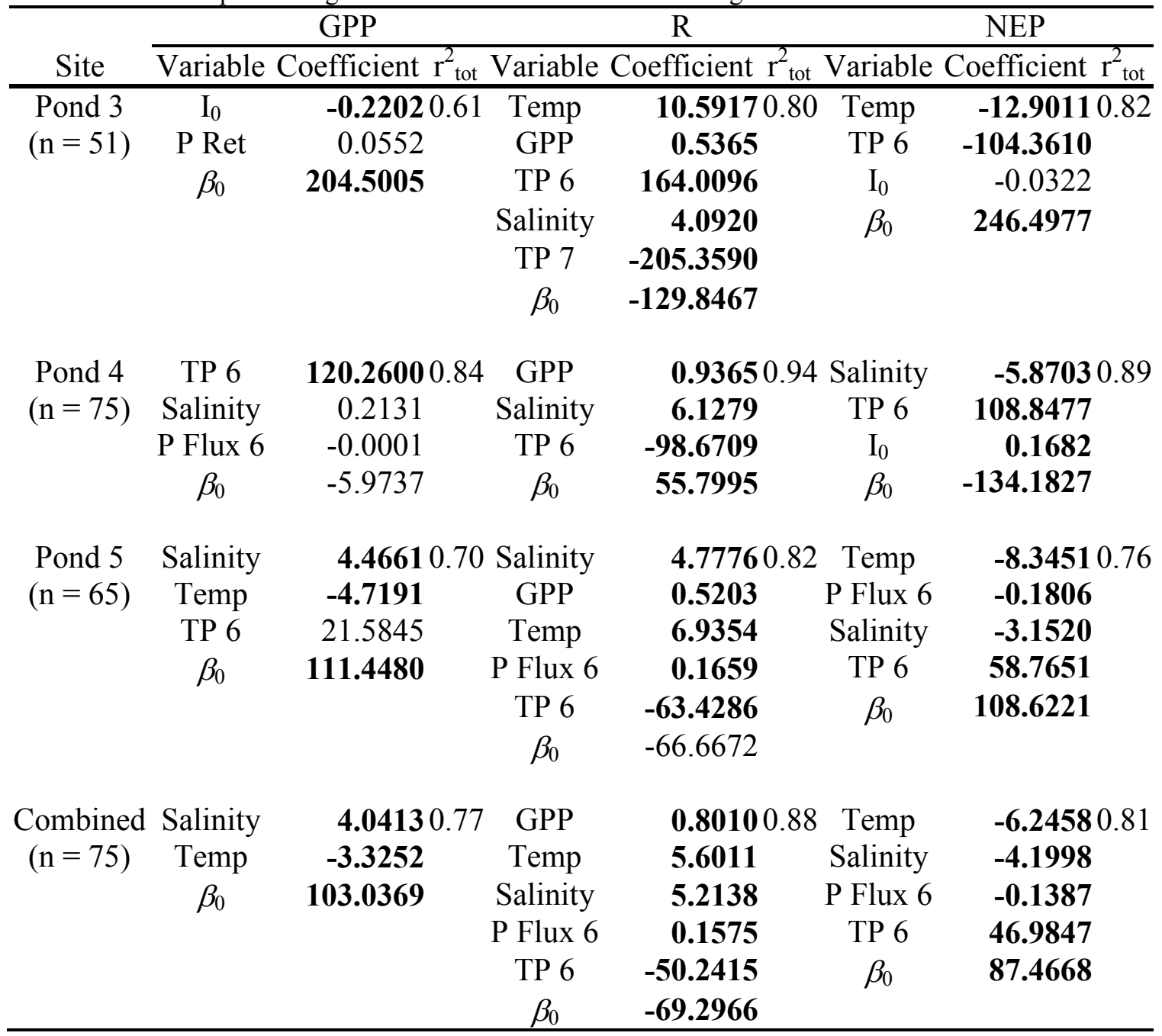


Water Residence Time

Estimates of water residence time (WRT) in estuarine Taylor River ponds were consistently between 1-5 days (Fig. 6). Pond size was directly related to WRT, with the largest pond (Pond 3) exhibiting the longest residence times. Furthermore, WRT increased in all ponds during dry season months. This seasonal effect was most pronounced in larger ponds as well as during years with very low freshwater flow within the Taylor Slough watershed (e.g. 2001, 2004, and 2007).

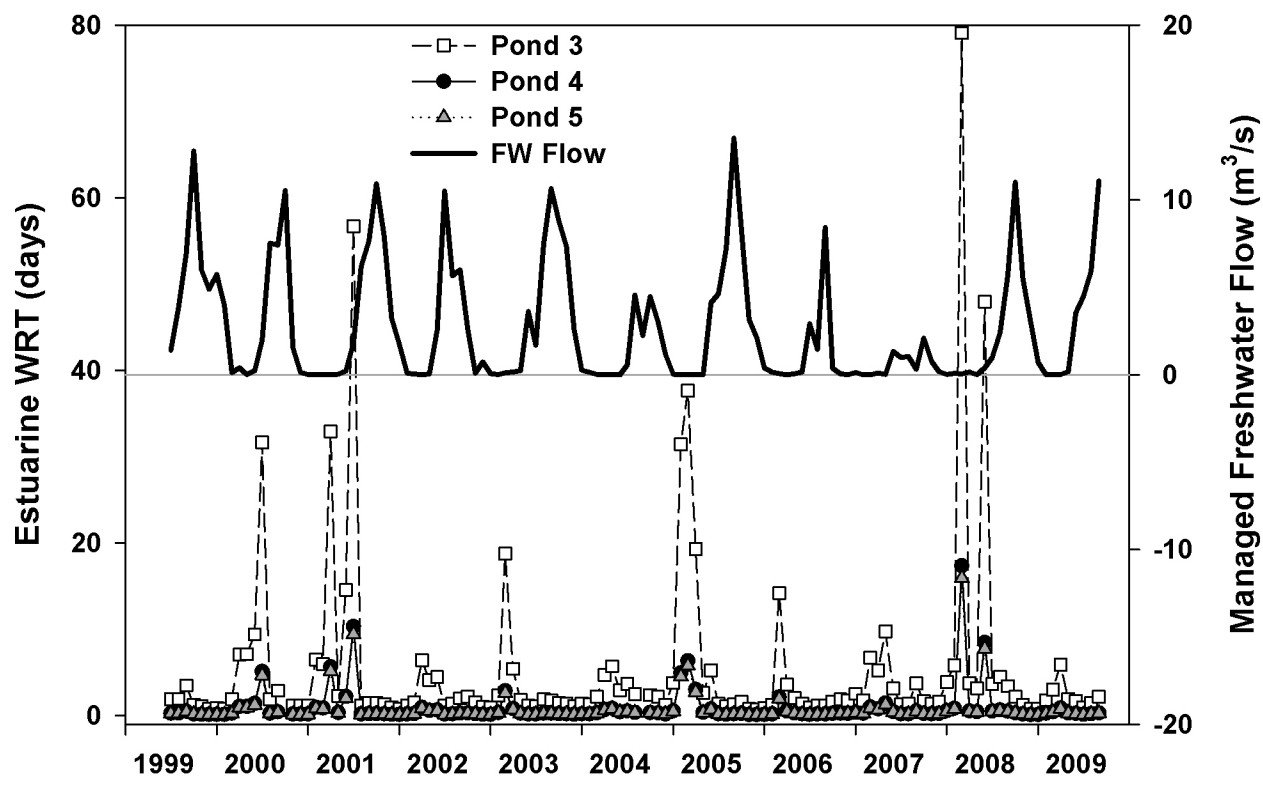

Figure 6. Monthly estimates of estuarine water residence time (WRT) in Pond 3 (open squares), Pond 4 (black circles), and Pond 5 (gray triangles) from 1999-2009. Discharge rates (black line) were measured upstream in freshwater Taylor Slough near human-managed water control structures.

Groundwater Dynamics

Groundwater salinity values were 20-30 psu at both TS/Ph-6 and TS/Ph-7 from June 2008 through June 2009 (Fig. 7a-b), and annual groundwater and surface water salinity medians were not significantly different from each other at either site. Similarly, 
groundwater salinity did not exhibit significant seasonal differences at either site, but I found significant seasonal shifts in surface water from hypersaline to oligohaline conditions both upstream $(p=0.008, \mathrm{n}=5)$ and downstream $(p<0.001, \mathrm{n}=5)$.

Groundwater TP concentrations at TS/Ph-6 were significantly higher compared with surface water TP $(p=0.011, \mathrm{n}=10$; Fig. $7 \mathrm{c}-\mathrm{d})$ but this pattern was not found at $\mathrm{TS} / \mathrm{Ph}-7$. No significant seasonal difference in TP concentrations were detected in groundwater at either site, and surface water TP concentration only differed between seasons at $\mathrm{TS} / \mathrm{Ph}-7(p=0.043, \mathrm{n}=5)$.

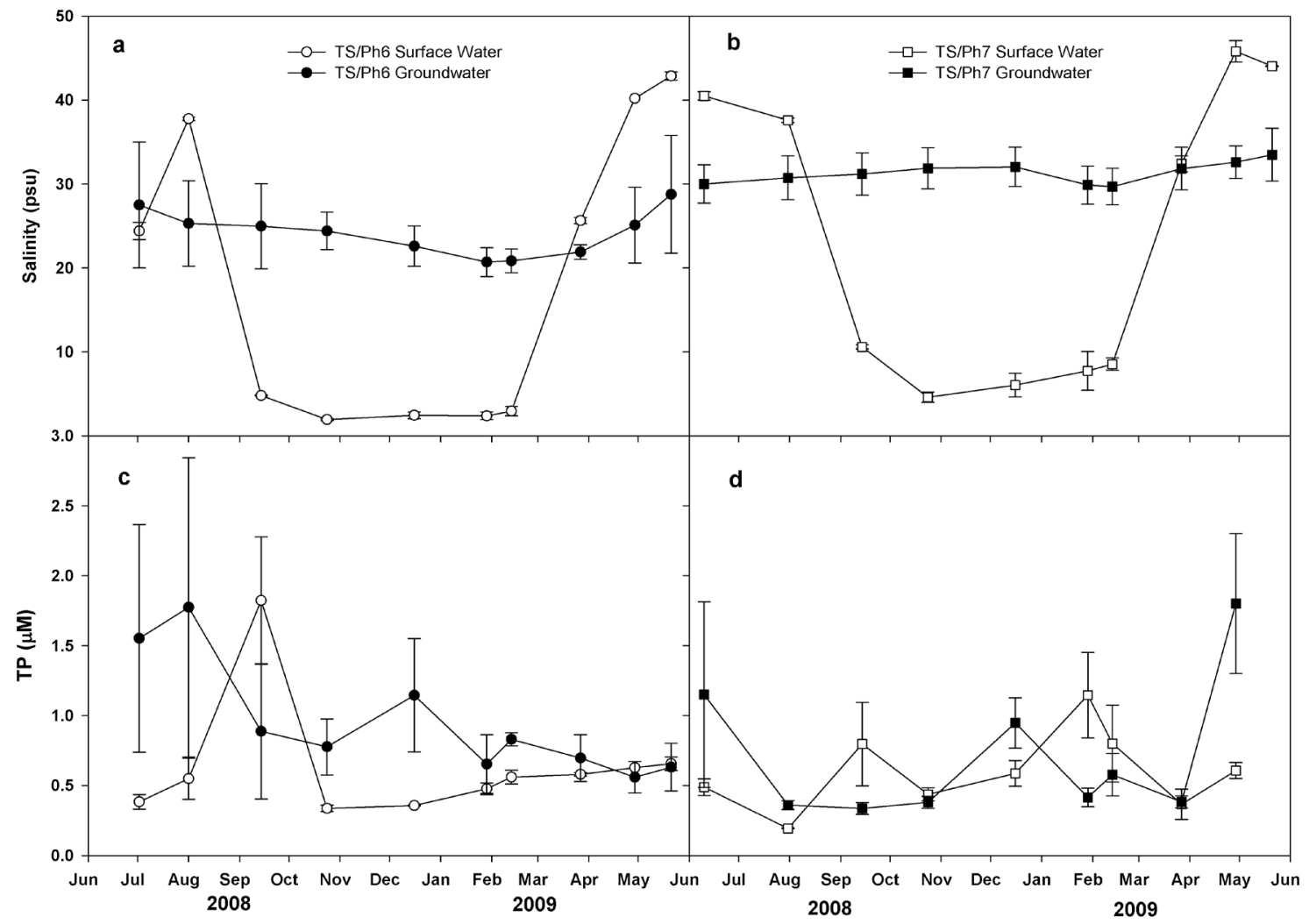

Figure 7. Mean groundwater concentrations of salinity (psu, panels a-b) and TP ( $\mu \mathrm{M}$, panels c-d) measured from wells at sites TS/Ph-6 (circles, left panels) and TS/Ph-7 (squares, right panels) from June 2008 to May 2009. Groundwater means are denoted by filled, black symbols and surface water means are denoted by open, white symbols. Error bars represent $\pm 1 \mathrm{SE}$. 


\section{Discussion}

I combined high-resolution measures of aquatic ecosystem metabolism with water quality data to investigate the importance of hydrological inputs of the limiting nutrient $\mathrm{P}$ on ecosystem dynamics in an oligotrophic estuary of the Florida Everglades. Specifically, I characterized long-term variation in Taylor River water quality as well as temporal and spatial variations in aquatic, whole-ecosystem metabolism estimates. I then evaluated the contribution of seasonally changing water quality drivers to variation in aquatic ecosystem metabolism rates. When I began this study, I expected that metabolic rates would be highest during times of the year when $\mathrm{P}$ concentrations were highest because this system is P-limited.

\section{Taylor River Metabolism}

Ecosystem metabolism dynamics often differed among study ponds in Taylor River. For example, in Pond 3 surface irradiance was the only significant contributor to GPP variation in the multiple regression analysis (Table 2), and the two variables were inversely correlated (Table 1). This relationship contrasted with positive correlation between irradiance and GPP averaged across all ponds, and is opposite from the intuitive relationship between primary production and light availability. Similarly, while TP concentrations both upstream and downstream of my study sites were always positively correlated with GPP, this relationship was not significant for all ponds and TP was not included in the Pond 3 and combined pond GPP multiple regression models. Salinity concentration, however, was a common predictor of GPP in my estuarine ponds. Models of pond R and NEP were less pond-specific and included a broader range of significant 
predictors than the models of GPP. For example, GPP, salinity, and upstream TP concentration were significant predictors of $\mathrm{R}$ in all ponds, while temperature was included in three out of the four R models. Similarly, pond NEP was frequently predicted by temperature, salinity, and upstream [TP]. The best models of pond GPP often explained much less variation than the best models of R and NEP in the same ponds. This suggests that GPP was much more spatially and temporally heterogeneous than either R or NEP. In oligotrophic Everglades ecosystems, such as the ponds in Taylor River, ecosystem productivity is highly sensitive to changes in the availability of P (Gaiser et al. 2004). Thus, it is not surprising that water column total phosphorus concentration was present in nearly all my models of ecosystem metabolism. Interestingly, even though [TP] was directly related to metabolism, estimates of P flux were inversely related ecosystem metabolism in Taylor River (Table 1). Given the Pdepauperate conditions of the southern Everglades, these P fluxes were largely governed by variability in water discharge rather than in $\mathrm{P}$ concentration. Thus, periods of high $\mathrm{P}$ flux coincided with high rates of surface water flushing during the wet season. The stronger relationship between metabolism and [TP], as opposed to P flux, emphasizes the importance of nutrient concentrations rather than bulk nutrient load to ecosystem function in Taylor River. Furthermore, the similar omnipresence of salinity as a significant driver of ecosystem metabolism suggests that salinity can indicate the timing of $\mathrm{P}$ availability to the Taylor River estuary.

The specific morphological and hydrological characteristics of each pond drive some of the observed differences in pond metabolism models. For example, Pond 4 lies at a unique location where the Taylor River channel turns $90^{\circ}$ to the east before turning 
southwards again at Pond 3 (Fig. 2). In addition, the surface water inlet and outlets are located solely in the northeastern portion of Pond 4. As a result, the northeastern section of Pond 4 experiences significantly more water flow than the remainder of the pond. Thus, the relative inactivity that I observed in Pond 4 metabolism during much of this study may indicate that my buoy was stationed at a particularly stagnant location in the pond that only mixes with the main river channel surface water during the strongest dry season hydrological forcings. Indeed, my estimates from Pond 4 showed periods of relatively low metabolic rates in November-December 2008, just before the 2009 dry season signal, and during the 2009-2010 wet season. Ponds 3 and 5 were most similar both hydrologically and metabolically, in that each are situated through direct southerly flow and the metabolism of each exhibited similar temporal variability.

Although each of the ponds included in this study have different hydrodynamic and morphological characteristics, the variable influence of environmental drivers on pond production rates may reflect the varying deployment dates of instrumented buoys in each pond. For example, measurements in Pond 3 began just after the large 2009 dry season productivity pulse observed in Ponds 4 and 5. The 2010 dry season was much shorter than that in 2009. As a result, the window of observed metabolism in Pond 3 was largely during the 2009-2010 wet season when TP and salinity were lowest. Furthermore, this low productivity continued into the summer months when solar irradiance was highest. Thus, during periods of a small seasonal signal, I found minimal connections between GPP and TP or salinity. In Pond 5, where my buoy deployment fully captured both the 2009 and 2010 dry seasons, I observed strong, positive relationships between GPP and irradiance, TP, and salinity. In contrast, pond R and NEP 
appeared largely unaffected by differential buoy deployment. The regression model of Pond $3 \mathrm{R}$ was nearly identical to that of $\mathrm{R}$ in Pond 5.

I observed net heterotrophy (GPP $<\mathrm{R}, \mathrm{NEP}<0)$ in the open water ponds of the Taylor River estuary throughout my study period. Net heterotrophy has also been found in freshwater Everglades wetlands (Hagerthey et al. 2010) as well as other freshwater (Cole et al. 2000, Hanson et al. 2003, Sand-Jensen and Staehr 2009) and estuarine ecosystems (Flores-Verdugo 1988, Smith et al. 1991, Smith and Hollibaugh 1993, Pradeep Ram et al. 2003, Duarte and Prairie 2005, Gupta et al. 2008). This heterotrophic activity must be driven by an allochthonous source of fixed carbon to subsidize aquatic ecosystem respiration. In the coastal Everglades, several researchers have investigated the potential for freshwater marsh-derived detritus to subsidize downstream estuaries. While Jaffé et al. (2001) showed that estuarine detritus contained a mix of upstream and downstream sources, more recent work has pointed towards local mangrove wetlands as the source of this organic carbon (Mead et al. 2005, Neto et al. 2006). These researchers repeatedly cited the mobility of Everglades detritus as a challenge to identifying its source and fate within the estuary. Thus, mobile wetland-produced detritus may ultimately collect in the numerous ponds within the southern Everglades ecotone where it would fuel the heterotrophy I observed.

Seasonality in the Coastal Everglades

The Greater Everglades landscape, spanning freshwater and estuarine wetlands, is characterized by very low water column P concentrations as a result of a unique combination of biogeochemical, climatic, geological, and hydrological factors (Noe et al. 
2001). Consequently, Everglades ecosystems are P-limited and extremely sensitive to $P$ inputs (Boyer et al. 1999, Noe et al. 2001, Gaiser et al. 2004). Thus, Childers (2006) proposed that ecosystem productivity in the southern Everglades ecotone should reflect availability of P. Instead of a sustained peak in ecosystem productivity in the coastal Everglades ecotone, fueled by elevated dry season P, I found that aquatic gross primary production (GPP) showed high seasonal fluctuations (Fig. 5). Upstream [TP] was correlated to GPP in two of my three ponds (Table 1) and was a frequent predictor of pond metabolism in my multiple regression models (Table 2). Seasonal fluctuations in estuarine water column primary production have been observed in both temperate estuaries (Alpine and Cloern 1992, Mallin et al. 1993, Smith and Hollibaugh 1993) and tropical estuaries (Flores-Verdugo et al. 1988, Valiela et al. 1997, Pradeep Ram et al. 2003, Souza et al. 2009). Usually, these seasonal differences were explained by regional rainfall and river discharge patterns that supply the estuary with the limiting nutrient. In contrast to these examples, however, I observed elevated ecosystem GPP during periods of low rainfall, low river discharge, high salinity, and high [TP]. This is because the limiting nutrient, $\mathrm{P}$, is not supplied to "upside-down" Everglades estuaries from a terrestrial source (Childers et al. 2006); instead, these estuaries obtain P from a combination of marine and groundwater sources (Childers 2006). However, marine P does not reach the southern Everglades because it is first sequestered by Florida Bay (see Fig. 2). 
Source of Phosphorus to Taylor River

The southern Everglades and the Taylor River estuary are micro-tidal and are hydrologically uncoupled from the Gulf of Mexico (GOM) by Florida Bay; therefore, these estuarine systems are much more oligotrophic than Everglades estuaries with a direct tidal connection to P from the GOM (Childers et al. 2006). Yet, in 14 years of water quality sampling, I observed repeated seasonal increases in water column TP within Taylor River that coincided with dry season increases in water column salinity. Price et al. (2010) found that high-salinity groundwater intruding into a carbonate aquifer can mobilize carbonate-bound $\mathrm{P}$ from bedrock and possibly be an important source of $\mathrm{P}$ to the Everglades ecotone region when low surface water levels allow groundwater upwelling, such as during the southern Florida dry season. My observations revealed that Taylor River groundwater remained saline ( 30psu) throughout my 2008-2009 sampling, and that the high groundwater salinity was consistent with the extent of seawater intrusion in the Biscayne Aquifer in the region (Fitterman et al. 1999, Price et al. 2003, Price et al. 2006). Zapata-Rios (2009) used a water balance approach to show that groundwater discharge to Taylor River was greatest between May and July. This coincided with the highest rates of groundwater discharge that I observed in May 2009. My estimates of ecosystem metabolism also showed greatest ecosystem GPP at this time, providing evidence that saline groundwater upwelling, $\mathrm{P}$ supply from groundwater, and aquatic ecosystem function are tightly coupled (Price et al. 2006, Childers 2006).

Taylor River groundwater TP concentrations were variable in space and time, and did not follow a seasonal pattern. Groundwater at my upstream TS/Ph-6 site revealed TP concentrations at or above $1 \mu \mathrm{M}$ throughout much of the 2008-2009 sampling period, 
despite surface water TP rarely exceeding $1 \mu \mathrm{M}$ in more than 14 years of FCE LTER water quality monitoring in Taylor River. Groundwater sampled farther downstream at TS/Ph-7 rarely exceeded $1 \mu \mathrm{M}$ TP. Although groundwater discharge rates were higher at $\mathrm{TS} / \mathrm{Ph}-7$, closer to the coast (Zapata-Rios 2009), this did not translate into higher $\mathrm{P}$ concentrations in the surface water in that region. Zapata-Rios (2009) reports an average groundwater discharge rate of $5.1 \mathrm{~mm} /$ day at TS/Ph-6 from May-June 2009, and $18.3 \mathrm{~mm} /$ day at TS/Ph-7 from March-June 2009. Applying these discharge rates across a $1 \mathrm{~m}^{2}$ area and multiplying by TP concentrations for the same time periods presented in this study $(0.63 \mu \mathrm{M}$ and $0.56 \mu \mathrm{M})$ results in estimates of average groundwater P fluxes of 3.2 $\mu \mathrm{mol} /$ day and $10.2 \mu \mathrm{mol} /$ day at $\mathrm{TS} / \mathrm{Ph}-6$ and $\mathrm{TS} / \mathrm{Ph}-7$, respectively. Total $\mathrm{P}$ concentration and flux estimates from $\mathrm{TS} / \mathrm{Ph}-6$ were more strongly related to observed rates of pond metabolism than identical metrics from downstream $\mathrm{TS} / \mathrm{Ph}-7$. Thus, although groundwater discharge and flux estimates at TS/Ph-6 are smaller in magnitude than those downstream at TS/Ph-7, these smaller rates, fueled by higher TP concentrations, have a greater impact on Taylor River surface water quality and aquatic ecosystem metabolism.

In addition to groundwater, $\mathrm{P}$ is being supplied to the Taylor River aquatic system via internal, biotic sources. Red mangrove (Rhizophora mangle) roots in my study system have been shown to tap into groundwater at the peat-limestone interface (about $1 \mathrm{~m}$ deep; Ewe et al. 2007). Davis and Childers (2007) showed that decomposition of mangrove litter increased water column TP in controlled experiments, but that this process was limited by the availability of labile carbon. Thus, groundwater P may first be "mined" by mangroves, then transferred to the aquatic system as senesced leaves 
where it is remineralized in ponds and creeks. Organic matter produced by phytoplankton is often highly labile (Biersmith and Benner 1998) and the addition of labile OM to oligotrophic Taylor River ponds could stimulate decomposition—so-called "priming"- of more refractory substrates, such as mangrove leaves. The primed remineralization of $\mathrm{P}$ from mangrove biomass would therefore be accelerated when autochthonous pond production is elevated during the dry season. Although the concept of respiratory priming originated in terrestrial ecosystems, Guenet et al. (2010) recently reviewed evidence suggesting that this effect may also apply to freshwater and marine environments. Lastly, solutes are concentrated in Taylor River during the dry season as a result of high evaporation and low precipitation rates. High estuarine water residence time during the dry season would amplify the effects of these processes by increasing the time that all of these processes are in contact with surface water, further increasing observed TP concentrations.

In an analysis of $\mathrm{P}$ dynamics in sediments of 48 different aquatic ecosystems, Caraco et al. (1990) found that, under oxic conditions, freshwater sediments tended to immobilize $\mathrm{P}$ while marine sediments tended to release $\mathrm{P}$. Release of $\mathrm{P}$ from marine sediments has been linked to the depletion of iron — and subsequent desorption of $\mathrm{P}$-as a result of sulfate reduction (Schindler 1985, Caraco et al. 1989, Caraco et al. 1993). In addition, saline water has been shown to release $\mathrm{P}$ bound to calcium carbonate (Price et al. 2010). In Taylor River the inter-annual oscillation from freshwater to hypersaline conditions could thus enable a corresponding pulse of P from estuarine sediments. Temporal variability in sulfate concentrations, and its specific interaction with $\mathrm{P}$ availability, should be an important topic of future research in Everglades estuaries. 
It is likely that these hydrologic, biotic, and abiotic factors all contribute towards observed TP dynamics in Taylor River. These mechanisms can interact to form a positive feedback in which the appearance of elevated water column P stimulates the production of labile, autochthonous carbon, which in turn primes the remineralization of additional $\mathrm{P}$ from mangrove biomass. This effect would be most pronounced in the upstream reaches of Taylor River, where groundwater upwelling is strongest, and during the dry season, when water residence times are highest. The positive feedback loop is then stabilized by the wet season flushing of precipitation- and management-derived surface water through Taylor River. Thus, water management and restoration activities in the Everglades have a large potential to influence estuarine ecosystem function.

\section{Conclusions}

This study showed a repeated, seasonal increase in surface water P concentrations that coincided with diminished surface water discharge rates and increasing salinity concentration within the Taylor River estuary of the Florida Everglades. During the estuarine "dry" season, high aquatic ecosystem metabolism rates were consistently associated with elevated upstream total phosphorus and salinity concentrations. Pulses in aquatic metabolism rates were coupled to the timing of $\mathrm{P}$ supply from groundwater upwelling as well as a potential suite of hydro-biogeochemical interactions. I provide evidence that freshwater discharge has observable impacts on aquatic ecosystem function in the oligotrophic estuaries of the Florida Everglades by controlling the availability of P to the ecosystem. Future water management decisions in South Florida must include the impact of changes in water delivery on downstream estuaries. 


\section{References}

Alpine, A.E. and J.E. Cloern. 1992. Trophic interactions and direct physical effects control phytoplankton biomass and production in an estuary. Limnology and Oceanography 37(5): 946-955.

Beach, C. M. and J. G. MacKinnon. 1978. A maximum likelihood procedure for regression with autocorrelated errors. Econometrica 46(1): 51-58.

Biersmith, A. and R. Benner. 1998. Carbohydrates in phytoplankton and freshly produced dissolved organic matter. Marine Chemistry 63: 131-144.

Burnham, K.P. and D.R. Anderson. 2002. Model selection and multimodel inference: a practical information-theoretic approach, 2nd edition. New York: Springer Science+Business Media, Inc.

Boyer, J. N., J. W. Fourqurean, and R. D. Jones. 1999. Seasonal and long-term trends in the water quality of Florida Bay (1989-1997). Estuaries 22: 417-430.

Caraco, N. F., J. J. Cole and G. E. Likens. 1989. Evidence for sulfate-controlled phosphorus release from sediments of aquatic systems. Nature 341(6240):316-318.

Caraco, N. F., J. J. Cole and G. E. Likens. 1990. A comparison of phosphorus immobilization in the sediments of freshwater and coastal marine systems. Biogeochemistry 9:277-290.

Caraco, N. F., J. J. Cole and G. E. Likens. 1993. Sulfate control of phosphorus availability in lakes: A test and re-evaluation of Hasler and Einsele's model. Hydrobiologia 253:275-280.

Carpenter, S.R., J. J. Cole, J. F. Kitchell, and M. L. Pace. 1998. Impact of dissolved organic carbon, phosphorus, and grazing on phytoplankton biomass and production in experimental lakes. Limnology and Oceanography 43(1): 73-80.

Childers, D. L., J. W. Day Jr., and H. N. McKellar Jr. 2000. Twenty more years of marsh and estuarine flux studies: Revisiting Nixon (1980). In: [M.P. Weinstein and D.Q. Kreeger, eds.] Concepts and Controversies in Tidal Marsh Ecology, pp. 391-423.

Childers, D.L. 2006. A synthesis of long-term research by the Florida Coastal Everglades LTER Program. Hydrobiologia 569(1):531-544.

Childers, D.L., J.N. Boyer, S.E. Davis, C.J. Madden, D.T. Rudnick, F.H. Sklar. 2006. Relating precipitation and water management to nutrient concentrations in the oligotrophic "upside-down" estuaries of the Florida Everglades. Limnology and Oceanography 51:602-616. 
Cole, J.J. and N.F. Caraco. 1998. Atmospheric exchange of carbon dioxide in a low-wind oligotrophic lake measured by the addition of $\mathrm{SF}_{6}$. Limnology and Oceanography 43: 657-656.

Cole, J.J., M.L. Pace, S.R. Carpenter, and J.F. Kitchell. 2000. Persistence of net heterotrophy in lakes during nutrient addition and food web manipulations. Limnology and Oceanography 45(8): 1718-1730.

Davis, S. E. III, D. L. Childers, J. W. Day Jr., D. T. Rudnick, F. H. Sklar. 2001. Wetlandwater column exchanges of carbon, nitrogen, and phosphorus in a southern Everglades dwarf mangrove. Estuaries 24(4): 610-622.

Davis, S.E. III and D.L. Childers. 2007. Importance of water source in controlling leaf leaching losses in a dwarf red mangrove (Rhizophora mangle L.) wetland. Estuarine, Coastal and Shelf Science 71: 194-201.

Dollar, S.J., S.V. Smith, S.M. Vink, S. Obrebski, J.T. Hollibaugh. 1991. Annual cycle of benthic nutrient fluxes in Tomales Bay, California, and contribution of the benthos to total ecosystem metabolism. Marine Ecology Progress Series 79(2): 115-125.

Duarte, C.M. and Y.T. Prairie. 2005. Prevalance of heterotrophy and atmospheric $\mathrm{CO}_{2}$ emissions from aquatic ecosystems. Ecosystems 8: 862-870.

Duever, M.J., J.F. Meeder, L.C. Meeder, and J.M. McCollom. 1994. The climate of South Florida and its role in shaping the Everglades ecosystem. In: [S.M. Davis and J.C. Ogden, eds.] Everglades: The Ecosystem and its Restoration, pp. 225-248, St. Lucie Press, Delray Beach, FL.

Durbin, J. 1960. Estimation of parameters in time-series regression models. Journal of the Royal Statistical Society, Series B (Methodological) 22(1): 139-153.

Ewe, S.M.L., E.E. Gaiser, D.L. Childers, D. Iwaniec, V.H. Rivera-Monroy, R.R. Twilley. 2006. Spatial and temporal patterns of aboveground net primary productivity (ANPP) along two freshwater-estuarine transects in the Florida Coastal Everglades. Hydrobiologia 569: 459-474.

Ewe, S.M.L., L. da S.L. Sternberg, and D.L. Childers. 2007. Seasonal plant water uptake patterns in the saline southeast Everglades ecotone. Oecologia 152(4): 607-616.

Fish, J. and M. Stewart. 1991. Hydrogeology of the surficial aquifer system, Dade County, Florida. U.S. Geological Survey. Water Resources Investigation Report 90-4108. 
Fitterman, D.V., M.Deszcz-Pan, and C.E. Stoddard. 1999. Results of time-domain electromagnetic soundings in Everglades National Park, Florida. U.S. Geological Survey, Open File Report., 99-426.

Flores-Verdugo, F.J., J.W. Day Jr., L. Mee, R. Briseño-Dueñas. 1988. Phytoplankton production and seasonal biomass variation of seagrass, Ruppia maritima L., in a tropical Mexican lagoon with an ephemeral inlet. Estuaries 11(1): 51-55.

Gaiser, E. E., L. J. Scinto, J. H. Richards, K. Jayachandran, D. L. Childers, J. C. Trexler, and R. D. Jones. 2004. Phosphorus in periphyton mats provides the best metric for detecting low-level P enrichment in an oligotrophic wetland. Water Research 38: 507516.

Gaiser, E.E., A. Zafiris, P.L. Ruiz, F.A.C. Tobias, M.S. Ross. 2006. Tracking rates of ecotone migration due to salt-water encroachment using fossil mollusks in coastal South Florida. Hydrobiologia 569: 237-257.

Guenet, B., M. Danger, L. Abbadie, and G. Lacroix. 2010. Priming effect: bridging the gap between terrestrial and aquatic ecology. Ecology 91: 2850-2861.

Gupta, G.V.M., V.V.S.S. Sarma, R.S. Robin, A.V. Raman, M. Jai Kumar, M. Rakesh, and B.R. Subramanian. 2008. Influence of net ecosystem metabolism in transferring riverine organic carbon to atmospheric $\mathrm{CO}_{2}$ in a tropical coastal lagoon (Chilka Lake, India). Biogeochemistry 87: 265-285.

Hagerthey, S.E., J.J. Cole, D. Kilbane. 2010. Aquatic metabolism in the Everglades: dominance of water column heterotrophy. Limnology and Oceanography 55(2): 653-666.

Hanson, P.C., D.L. Bade, S.R. Carpenter, T.K. Kratz. 2003. Lake metabolism: relationships with dissolved organic carbon and phosphorus. Limnology and Oceanography 48(3): 1112-1119.

Hobbie, J.E. (ed.) 2000. Estuarine science: the key to progress in coastal ecological research. In: Estuarine Science: A Synthetic Approach to Research and Practice, pp. 111, Island Press, Washington, DC.

Howarth, R.W., A. Sharpley, and D. Walker. 2002. Sources of nutrient pollution to coastal waters in the United States: implications for achieving coastal water quality goals. Estuaries 25(4b): 656-676.

Jaffé R., R. Mead, M.E. Hernandez, M.C. Peralba, O.A. DiGuida. 2001. Origin and transport of sedimentary organic matter in two subtropical estuaries: a comparative, biomarker-based study. Organic Geochemistry 32: 507-526. 
Jähne, B., O. Münnich, R. Bösinger, A. Dutzi, W. Huber, and P. Libner. 1987. On the parameters influencing air-water gas exchange. Journal of Geophysical Research 92: 1937-1949.

Lichstein, J.W., T.R. Simons, S.A. Shriner, K.E. Franzreb. 2002. Spatial autocorrelation and autoregressive models in ecology. Ecological Monographs 72(3): 445-463.

Light, S. S. and J. W. Dineen. 1994. Water control in the Everglades: a historical perspective. In: [S.M. Davis and J.C. Ogden, eds.] Everglades: The Ecosystem and its Restoration. St. Lucie Press, Delray Beach, FL.

Mallin, M.A., H.W. Paerl, J. Rudek, P.W. Bates. 1993. Regulation of estuarine primary production by watershed rainfall and river flow. Marine Ecology Progress Series 93: 199-203.

Mead R., Y. Xu, J. Chong, R. Jaffé. 2005. Sediment and soil organic matter source assessment as revealed by the molecular distribution and carbon isotopic composition of n-alkanes. Organic Geochemistry 36: 363-370.

Milliman, J.D. and J.P.M. Syvitski. 1992. Geomorphic tectonic control of sediment discharge to the ocean - the importance of small mountainous rivers. Journal of Geology 100: 525-554.

Neto R.R., R.N. Mead, J.W. Louda, R. Jaffé. 2006. Organic biogeochemistry of detrital flocculent material (floc) in a subtropical, coastal wetland. Biogeochemistry 77: 283-304.

Nixon, S. W. 1980. Between coastal marshes and coastal waters - a review of twenty years of speculation and research on the role of salt marshes in estuarine productivity and water chemistry. In: Estuarine and wetland processes with emphasis on modeling, Plenum Publishing, NY. p 437-525.

Noe, G.B., D.L. Childers, R.D. Jones. 2001. Phosphorus biogeochemistry and the impact of phosphorus enrichment: why is the Everglades so unique? Ecosystems 4: 603-624.

Odum, E. P. 1968. A research challenge: evaluating the productivity of coastal and estuarine water. In: Keiffner, E. (ed.) Proceedings of the Second Sea Grant Conference, Univ. of Rhode Island, Newport, Rhode Island, p 63-64.

Odum H.T. 1956. Primary production in flowing waters. Limnology and Oceanography 1: $102-117$.

Pradeep Ram, A.S., S. Nair, and D. Chandramohan. 2003. Seasonal shift in net ecosystem production in a tropical estuary. Limnology and Oceanography 48(4): 1601-1607. 
Price, R.M, Z. Top, J.D. Happell, and P.K. Swart, 2003. Use of tritium and helium to define groundwater flow conditions in Everglades National Park. Water Resources Research 39(9): 1267.

Price, R.M., P.K. Swart, J.W. Fourqurean, 2006. Coastal groundwater discharge: an additional source of phosphorus for the oligotrophic wetlands of the Everglades. Hydrobiologia 569: 23-36.

Price, R.M., M.R. Savabi, J.L. Jolicoeur, and S. Roy. 2010. Adsorption and desorption of phosphate on limestone in experiments simulating seawater intrusion. Applied Geochemistry 25: 1085-1091.

Ross, M.S., J.F. Meeder, J.P. Sah, P.L. Ruiz, and G.J. Telesnicki. 2000. The Southeast saline Everglades revisited: 50 years of coastal vegetation change. Journal of Vegetation Science 11: 101-112.

Sand-Jensen, K. and P.A. Staehr. 2009. Net heterotrophy in small Danish lakes: a widespread feature over gradients in trophic status and land cover. Ecosystems 12: 336348.

Schindler, D.W. 1985. Coupling of elemental cycles by organisms: evidence from wholelake chemical perturbations. In: [W. Stumm, ed.] Chemical Processes in Lakes. Wiley, p. 225-250.

Sklar, F.H., M.J. Chimney, S. Newman, P. McCormick, D. Gawlik, S. Miao, C. McVoy, W. Said, J. Newman, C. Coronado, G. Crozier, M. Korvela, and K. Rutchey. 2005. The ecological-societal underpinnings of Everglades restoration. Frontiers in Ecology and the Environment 3: 161-169.

Smith, S.V. 1985. Physical, chemical, and biological characteristics of CO2 gas flux across the air-water interface. Plant, Cell and Environment 8: 387-398.

Smith, S.V., J.T. Hollibaugh, S.J. Dollar, and S. Vink. 1991. Tomales Bay metabolism: C-N-P stoichiometry and ecosystem heterotrophy at the land-sea interface. Estuarine, Coastal and Shelf Science 33(3): 223-257.

Smith, S.V., and J.T. Hollibaugh. 1993. Coastal metabolism and the oceanic organic carbon balance. Reviews of Geophysics 31(1) 75-89.

Solorzano L., and J.H. Sharp. 1980. Determination of total dissolved phosphorus and particulate phosphorus in natural waters. Limnology and Oceanography 25: 754-758.

Souza, M.F.L., V.R. Gomes, S.S. Freitas, R.C.B. Andrade, B. Knoppers. 2009. Net ecosystem metabolism and nonconservative fluxes of organic matter in a tropical mangrove estuary, Piauí River (NE of Brazil). Estuaries and Coasts 32(1): 111-122. 
Staehr, P.A., D. Bade, M.C. Van de Bogert, G.R. Koch, C. Williamson, P. Hanson, J. J. Cole, and T. Kratz. 2010a. Lake metabolism and the diel oxygen technique: state of the science. Limnology and Oceanography: Methods 8: 628-644.

Staehr, P.A., K. Sand-Jensen, A.L. Raun, B. Nilsson, and J. Kidmose. 2010b. Drivers of metabolism and net heterotrophy in contrasting lakes. Limnology and Oceanography 55(2): 817-830.

Sutula, M. A., B. C. Perez, E. Reyes, D. L. Childers, S. Davis, J. W. Day Jr., D. Rudnick, F. Sklar. 2003. Factors affecting the spatial and temporal variability in material exchange between the southern Everglades wetlands and Florida Bay (USA). Estuarine, Coastal and Shelf Science 57: 757-781.

Valiela, I., J. McClelland, J. Hauxwell, P.J. Behr, D. Hersh, and K. Foreman. 1997. Macroalgal blooms in shallow estuaries: controls and ecophysiological and ecosystem consequences. Limnology and Oceanography 42(5): 1105-1118.

Wanninkhof, R. 1992. Relationship between wind speed and gas exchange over the ocean. Journal of Geophysical Research 97: 7373-7382.

Zapata-Rios, X. 2009. Groundwater/surface water interactions in Taylor SloughEverglades National Park. M.S. Thesis in Geosciences, Florida International University, $183 \mathrm{pp}$. 
III. Ecological and physical characteristics of flocculent detritus in the Everglades: A comparison of methods

Introduction

Particulate organic material—detritus—often plays a strong role in wetland ecosystem function and forms the base of many aquatic food webs (Teal 1962, Odum and Heald 1975, Azam et al. 1983, Wallace et al. 1997, Williams and Trexler 2006). These labile, organic pools increase in importance in oligotrophic ecosystems because nutrients become trapped in organic forms, quickly recycled from old to new biomass (sensu Odum 1969, Vitousek 1982, Vitousek and Sanford 1986). Therefore, in oligotrophic ecosystems, nutrients spend little time in inorganic forms and understanding detrital carbon pools is critical to understanding ecosystem function. In this study, I examine physical and biogeochemical properties of flocculent detritus in two oligotrophic Everglades wetlands.

A surface layer of unconsolidated, flocculent detritus ("floc") is a common feature in wetlands (Schoenberg 1988, D’Angelo and Reddy 1994, Graham and Manning 2007, Hornung and Foote 2008) and often plays an important role in nutrient uptake and retention in wetlands constructed for wastewater treatment (Hafner and Jewell 2006, Kadlec and Wallace 2009). Floc particles are a highly porous matrix of inorganic and organic constituents, providing a high surface area for microbial colonization (Liss 1996, Droppo et al. 1997, Droppo 2001). Detrital floc material is abundant in the Florida Everglades and several biomarker and isotopic studies have linked it to wetland primary producers (Jaffé et al. 2001, Mead et al. 2005, Neto et al. 2006), especially periphyton 
(Noe et al. 2002, Noe et al. 2003) and Utricularia spp. (Troxler and Richards 2009). Floc in the Everglades has been shown to contain a higher proportion of organic matter and is more biogeochemically active than underlying soils (Noe et al. 2003, Neto et al. 2006, Wright et al. 2009). Although flocculent detritus is ubiquitous across the Everglades landscape, recent data point towards substantial spatiotemporal variability in floc quality and quantity (G. Losada, unpublished data). For example, Neto et al. (2006) showed that floc from an Everglades freshwater marsh was higher in both organic carbon and total nitrogen content than floc from the downstream coastal mangrove estuary.

Floc particles are particularly susceptible to aqueous transport (Droppo 2001) and therefore provide a vector for the downstream transport of POM and nutrients (Droppo et al. 1997, Neto et al. 2006, Larsen et al. 2009b, Noe et al. 2010). Some studies suggested that particle size and organic matter content can affect the distance of floc transport (Droppo et al. 1997, Larsen 2009a). Respiration of floc has been shown to exceed microbial photosynthesis within the floc matrix (Wood 2005). This net heterotrophic nature of floc, in combination with photo-dissolution of floc organic matter (Pisani et al. 2011), can result in the remineralization of stored carbon and nutrients during and after transport. Thus, in oligotrophic freshwater marshes and mangrove estuaries of the Everglades landscape, the flow-mediated transport of relatively nutrient-rich flocculent detritus may be a key nutrient source fueling downstream ecosystem productivity.

Despite extensive research on flocculent detritus over the past decade, particularly in Everglades wetlands, the analytical separation of floc from the underlying soil surface remains a challenge. It has been shown that Everglades floc is ecologically different than soil (Noe et al. 2003, Neto et al. 2006), however current sampling techniques inevitably 
result in a sample containing some proportion of both floc and underlying soil. Previous studies have used various methods to attempt to exclude soil. One popular method is the inversion of a thin soil core in order to separate freely-pouring floc from the more dense soil underneath (Noe et al. 2002, Neto et al. 2006, Troxler and Richards 2009, Pisani et al. 2011). Other researchers have suctioned floc samples directly off the wetland soil surface (Larsen et al. 2009a) while others have tried advective traps (Wood 2005) or simply taken grab samples of wetland substrate (Jaffé 2001, Mead et al. 2005). In this study, I compared a number of floc and soil sampling methods to characterize Everglades floc with the aim to answer the following questions: a) Do differences exist between floc collected with different sampling methods as a result of capturing varying quantities of wetland floc and soil?; and, b) Does wetland type affect the physical and biogeochemical characteristics of floc and the floc-soil interface, necessitating different sampling methods?

Methods

Site Description

The Greater Everglades landscape is extremely P-limited, oligotrophic, and very sensitive to changes in P availability (Boyer et al. 1999, Noe et al. 2001, Gaiser et al. 2004, Gaiser et al. 2005). The climate of South Florida is subtropical and marked by a wet season from June through November and a dry season from December through May (Duever et al. 1994). I collected flocculent detritus from two sites—one freshwater and one estuarine_-within Everglades National Park (Fig. 1). My freshwater marsh collection site was located in Shark River Slough at Florida Coastal Everglades Long- 
Term Ecological Research (FCE LTER; www.fce.lternet.edu) site SRS-2 (25.5497 N, $\left.80.7852^{\circ} \mathrm{W}\right)$. Shark River Slough (SRS) is an expansive, shallow slough linking northern Everglades marshes to the Gulf of Mexico via slow-moving surface water sheet flow (Light and Dineen 1994). Vegetation communities within SRS overlie peat soils and are dominated by elevated sawgrass (Cladium jamaicense) ridges and deeper spikerush (Eleocharis spp.) sloughs. In addition to these vegetation communities, periphyton is an important primary producer at this site (Ewe et al. 2006). Estuarine floc was collected from the Taylor River estuary at FCE LTER site TS/Ph $6\left(25.2161^{\circ} \mathrm{N}, 80.6510^{\circ} \mathrm{W}\right)$. Taylor River is one of the most important hydrologic connections between southern Everglades freshwater marshes and northeastern Florida Bay (Davis et al. 2001, Sutula et al. 2003) and is dominated by scrub red mangrove (Rhizophora mangle). Up to two meters of peat and marl deposits lie on top of karstic, carbonate bedrock. This estuarine system experiences negligible astronomical tide. As such, it is more susceptible to rainfall/runoff-driven and wind-forced fluctuations in flow. 


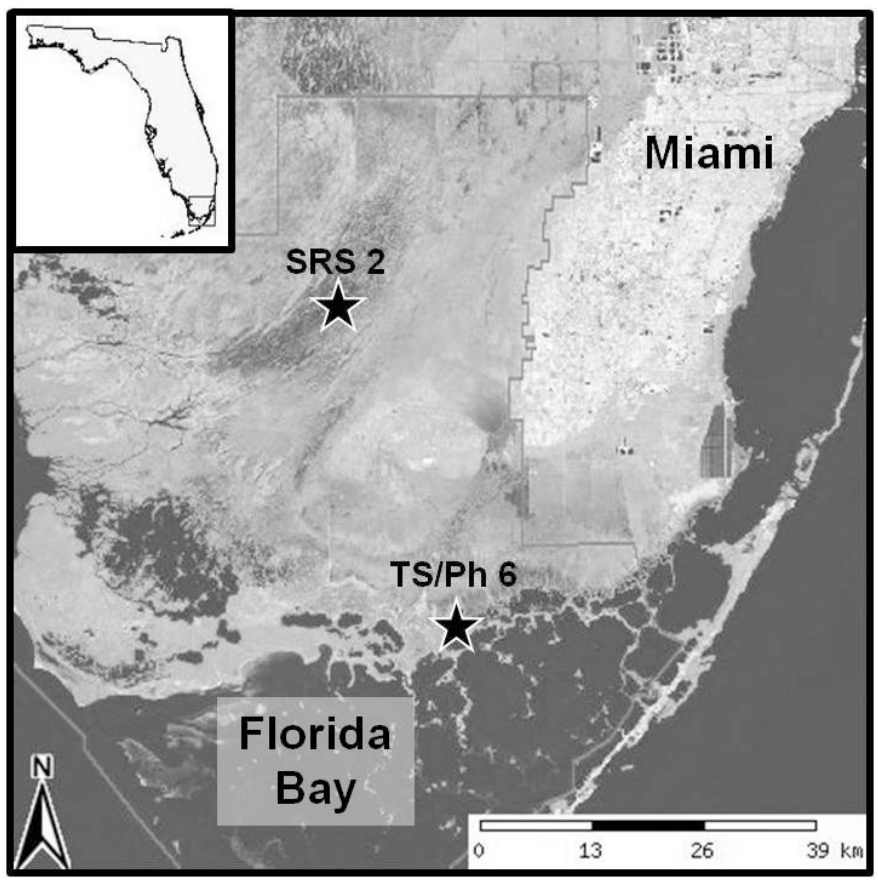

Figure 1. Location of floc collection sites (black stars) at freshwater marsh SRS-2 and mangrove estuary TS/Ph-6. These sites are part of the FCE LTER program and are located within Everglades National Park (outlined in grey).

Floc Collection Methods

I collected soil and flocculent detritus samples in April 2010 from slough habitat of the SRS 2 freshwater marsh and from the swamp surface at TS/Ph 6 mangrove estuary sites. Floc was collected at each site using four methods derived from previously published studies; I also collected samples of the underlying soil (Table 1, Fig. 2). Two methods involved using a peristaltic pump to suction floc material through vinyl tubing into $1 \mathrm{~L}$ plastic bottles. The suction-soil (SS) method vacuumed floc directly off the soil surface (Larsen et al. 2009a, Larsen et al. 2009b). As a potential improvement on this method, I also developed the suction-sheet (ST) method, wherein I vacuumed floc after it was allowed to accumulate for one month on top of $1 \times 2 \mathrm{~m}$ fiberglass sheets. The sheets were deployed directly on top of the existing soil+floc wetland surface in March 2010. In 
addition, floc was captured within hollow $10 \times 4 \times 4 \mathrm{~cm}(\mathrm{LxWxH})$ acrylic advective traps, colloquially referred to a "flocculators" (F; Wood 2005). The flocculator traps were deployed onto the soil surface for one month before the entry and exit doors were gently lowered in April 2010, effectively trapping the water and the associated floc sample. Lastly, I collected floc using a $2.5 \mathrm{~cm}$-diameter plastic core (C) with a sharpened bottom edge (Noe et al. 2002, Neto et al. 2006, Troxler et al. 2009, and Pisani et al. 2011). In this method, floc is defined as the material overlying the soil that can be decanted upon inversion of the core tube while a plunger with a diameter smaller than the core is used to hold the underlying, more dense soil in place. I aggregated floc from multiple cores into $1 \mathrm{~L}$ plastic bottles until a total sample volume of approximately $250 \mathrm{ml}$ was obtained. The remaining, lower portion of the core material was collected as a soil (S) sample for the site. I stored the bottles of collected floc in the dark on ice during transport from the field sites, then stored them in a laboratory refrigerator until processing.

Table 1. Methods used in this study to collect flocculent detritus

\begin{tabular}{lccc}
\hline \multicolumn{1}{c}{ Method } & Abbreviation & $\begin{array}{c}\text { Water \& Floc } \\
\text { Volume Collected Required }\end{array}$ & References \\
\hline Suction over Soil & SS & $100-1000 \mathrm{ml}$ minutes Larsen et al. 2009a \\
Suction over Sheet & ST & $100-1000 \mathrm{ml}$ weeks this study \\
Flocculator & F & $100-500 \mathrm{ml}$ hours to Wood 2005 \\
Core & $\mathrm{C}$ & $10-250 \mathrm{ml}$ minutes Noe et al. 2002 \\
Soil & S & $10-250 \mathrm{ml}$ minutes Noe et al. 2002 \\
\hline
\end{tabular}


a) Suction over Soil

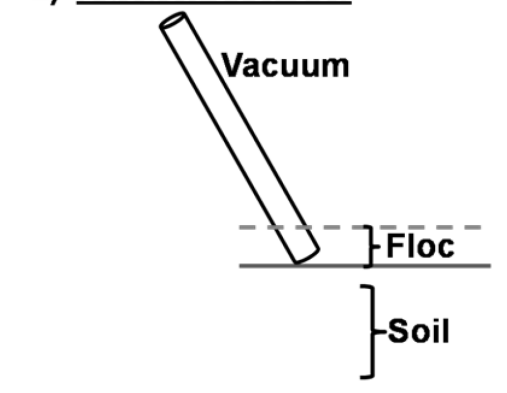

b) Suction over Sheet

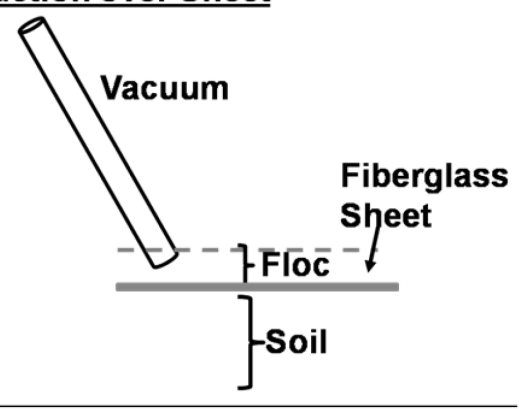

c) Flocculator

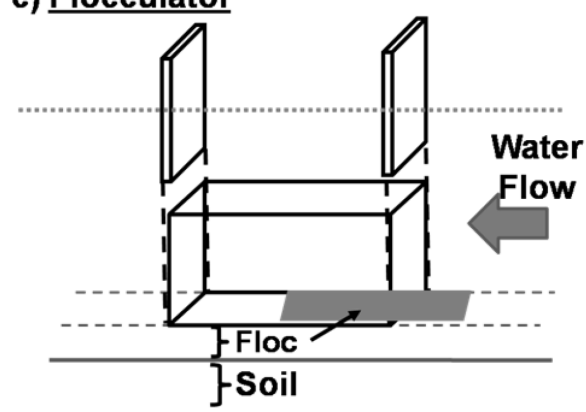

d) Core and Soil

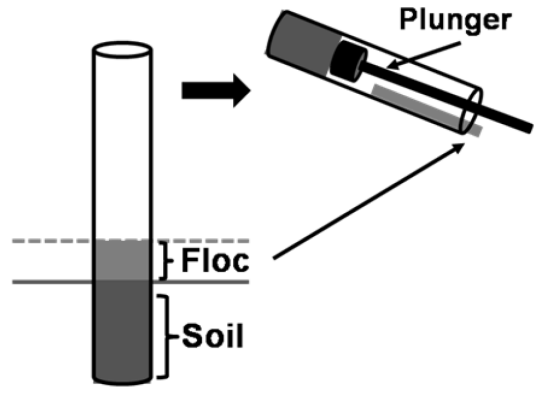

Figure 2. Diagrams of the four floc collection methods used in this study: a) suction of floc from over the soil surface ("SS"); b) suction of floc after it has accumulated over a fiberglass sheet ("ST"); c) capture of floc inside advective Flocculator chambers ("F"); and, d) capturing floc with a core and then pouring the floc into a container ("C"). The soil remaining at the bottom of the core method was used as my sample of underlying soil ("S").

Floc Analysis

I dried all floc and soil samples at $70^{\circ} \mathrm{C}$ prior to analysis. Bulk density was calculated as the dry weight of a $250 \mathrm{ml}$ subsample of wet material $(\mathrm{n}=1)$; this subsample was then set aside for isotope analysis. I determined percent organic matter $(\% \mathrm{OM})$ of floc and soil material from mass lost following combustion of dried samples at $500^{\circ} \mathrm{C}$ for 4 hours $(n=10)$.

I analyzed floc and soil $\% \mathrm{C}, \% \mathrm{~N}, \delta^{13} \mathrm{C}$, and $\delta^{15} \mathrm{~N}$ composition at the Southeast Environmental Research Center's Stable Isotope Laboratory at Florida International University. Dried, homogenized floc and soil samples were analyzed for $\% \mathrm{C}$ and $\% \mathrm{~N}$ 
with a Carlo Erba elemental analyzer (Thermo Fisher Scientific Inc., Waltham, MA, USA). I calculated floc $\mathrm{C}: \mathrm{N}$ mass ratios based on these data. Floc and soil $\delta^{13} \mathrm{C}$ and $\delta$

${ }^{15} \mathrm{~N}$ were analyzed using a continuous-flow isotope-ratio mass spectrometer (Finnigan Delta C, Thermo Fisher Scientific Inc., Waltham, MA, USA). I used $\delta$ notation (\%o) to express ${ }^{13} \mathrm{C}$ and ${ }^{15} \mathrm{~N}$ isotopic composition of soil and floc:

$$
\delta \%=\left(R_{\text {sample }} / R_{\text {standard }}-1\right) \times 1000
$$

where $R_{\text {sample }}$ is the ratio of heavy to light isotope $\left({ }^{13} \mathrm{C} /{ }^{12} \mathrm{C}\right.$ or $\left.{ }^{15} \mathrm{~N} /{ }^{14} \mathrm{~N}\right)$ in my samples and $R_{\text {standard }}$ is the ratio of heavy to light isotope in a standard (Vienna PeeDee Belemnite for $\mathrm{C}$ and atmospheric air for N). Prior to elemental and isotopic analysis, all samples were decarbonated using $1 \mathrm{M} \mathrm{HCl}$.

I determined settling velocity of floc particles by adding small spoonfuls of wet floc into top-loading, graduated Imhoff cones filled with wetland surface water from the same site (Wong and Piedrahita 2000). Settling velocity was calculated as the time taken for random, individual floc particles to fall $10 \mathrm{~cm}$ through the middle of the water column. This process was repeated until a total of 50 floc particles were observed from each floc collection method $(\mathrm{n}=50)$.

Statistical Analyses

I examined the influence of wetland type and methodological differences on floc and soil \%OM, C and $\mathrm{N}$ composition, settling velocity, and isotopic composition using two-way analysis of variance (ANOVA) with wetland type and collection method as treatments. When significant differences between treatment means were detected with the ANOVA, I conducted post-hoc pairwise comparisons using the Holm-Sidak test. 
These analyses were performed using SigmaPlot 11.0 (C 2008 Systat Software, Inc.). An $\alpha=0.05$ was used to determine significance in all statistical tests in this study.

I evaluated multivariate differences between sampling methods and wetland type with the non-metric multidimensional scaling (NMDS) routine in PRIMER 6.1. The NMDS was built using Bray-Curtis similarity calculated between each wetland-method pair using means of bulk density, $\% \mathrm{OM}, \% \mathrm{C}, \% \mathrm{~N}, \delta^{13} \mathrm{C}$, and $\delta^{15} \mathrm{~N}$. Clusters within the NMDS ordination were determined using hierarchical cluster analysis in PRIMER 6.1 with Bray-Curtis similarity thresholds at 80 and 90 similarity.

Results

Differences Among Methods

The effect of sampling method on floc properties varied extensively across my measured parameters (Table 2). At the freshwater marsh site, the ST method captured floc that was significantly different than soil with respect to five response variables $\left(\% \mathrm{OM}, \% \mathrm{~N}, \mathrm{C}: \mathrm{N}, \delta^{13} \mathrm{C}\right.$, and $\delta^{15} \mathrm{~N}$ ) while the other three methods exhibited significant differences for four variables each $\left(\% \mathrm{~N}, \mathrm{C}: \mathrm{N}, \delta^{13} \mathrm{C}\right.$, and $\left.\delta^{15} \mathrm{~N}\right)$. Floc $\% \mathrm{C}$ and $\mathrm{SV}$ did not differ among methods at either site.

Floc $\% \mathrm{OM}$ at the freshwater marsh site was significantly different from soil only with the ST method (Table 2; $<<0.001$ ). Percent OM of SS floc was significantly different from that of all other methods and ST and F floc \%OM was also significantly different. Floc from all methods had significantly different $\% \mathrm{~N}$ content and $\mathrm{C}: \mathrm{N}$ than soil but methods did not differ from each other ( $<<0.001$ for all pairwise comparisons). Soil $\delta^{13} \mathrm{C}$ and $\delta^{15} \mathrm{~N}$ differed significantly between all floc samples ( $\mathrm{p}<0.001$ for all pairwise 
comparisons). Collection methods at the freshwater marsh site exhibited significantly different isotopic compositions except for the SS and F methods.

At the mangrove estuary site, all methods collected floc that was significantly different in $\% \mathrm{OM}$ compared with soil (Table $2 ; \mathrm{p}<0.001$ for all pairwise comparisons). The SS and ST methods were not different from each other but both were significantly different from the $\mathrm{F}$ and $\mathrm{C}$ methods. In addition, every floc collection method captured floc that was significantly different in $\% \mathrm{~N}$ and $\mathrm{C}: \mathrm{N}$ relative to soil values ( $\mathrm{p}<0.001$ for all pairwise comparisons). Collection methods were not different from each other with regard to $\% \mathrm{~N}$ while the core method was the only method different from the others in $\mathrm{C}: \mathrm{N}(\mathrm{p}<0.001)$. Soil and floc collection methods all showed significantly different $\delta^{13} \mathrm{C}$ signatures at the mangrove estuary site. Floc collection methods were also different from each other with respect to $\delta^{15} \mathrm{~N}$ except that SS floc was not significantly different from wetland soil. 
Table 2. Sample means of soil and floc bulk density, percent organic matter $(\% \mathrm{OM})$, settling velocity (SV), percent carbon $(\% \mathrm{C})$, percent nitrogen $(\% \mathrm{~N})$, ratio of carbon to nitrogen $(\mathrm{C}: \mathrm{N}),{ }^{13} \mathrm{C}$, and ${ }^{15} \mathrm{~N}$ isotopic composition. Samples were collected from two wetland types using different collection methods: $\mathrm{SS}=$ suction over soil, $\mathrm{ST}=$ suction over sheet, $\mathrm{F}=$ flocculator, $\mathrm{C}=$ core, $\mathrm{S}=$ soil. Bold text indicates a floc sample significantly different from soil.

\begin{tabular}{|c|c|c|c|c|c|c|c|c|}
\hline & $\begin{array}{c}\text { Bulk Density } \\
(\mathrm{g} / \mathrm{ml} ; \mathrm{n}=1)\end{array}$ & $\begin{array}{l}\% \mathrm{OM} \\
(\mathrm{n}=10)\end{array}$ & $\begin{array}{c}\mathrm{SV} \\
(\mathrm{cm} / \mathrm{s} ; \mathrm{n}=50)\end{array}$ & $\begin{array}{c}\% \mathrm{C} \\
(n=3)\end{array}$ & $\begin{array}{c}\% \mathrm{~N} \\
(\mathrm{n}=3)\end{array}$ & $\begin{array}{c}C: N \\
(n=3)\end{array}$ & $\begin{array}{c}\delta^{13} \mathrm{C} \\
(\% \circ ; n=3)\end{array}$ & $\begin{array}{c}\delta^{15} \mathrm{~N} \\
(\% \circ ; n=3)\end{array}$ \\
\hline \multicolumn{9}{|l|}{ Freshwater Marsh } \\
\hline $\mathrm{SS}$ & 0.028 & $83.5^{\mathrm{la}}$ & $0.86^{\text {Ia }}$ & $42.99^{\text {Ia }}$ & $3.76^{\mathrm{Ia}}$ & $11.45^{\mathrm{Ia}}$ & $-31.90^{\text {Ia }}$ & $3.25^{\mathrm{Ia}}$ \\
\hline ST & 0.028 & $61.2^{\mathrm{Ib}}$ & $0.91^{\text {Ia }}$ & $41.97^{\mathrm{Ia}}$ & $3.73^{\mathrm{Ia}}$ & $11.26^{\mathrm{Ia}}$ & $-31.64^{\mathrm{Ib}}$ & $4.16^{\mathrm{Ib}}$ \\
\hline $\mathrm{F}$ & 0.028 & $72.5^{\mathrm{Ic}}$ & $0.73^{\text {Ia }}$ & $42.96^{\mathrm{Ia}}$ & $3.82^{\mathrm{Ia}}$ & $11.25^{\mathrm{Ia}}$ & $-32.06^{\mathrm{Ia}}$ & $3.25^{\mathrm{Ia}}$ \\
\hline $\mathrm{C}$ & 0.035 & $63.5^{\mathrm{Ib}, \mathrm{c}}$ & $0.69^{\mathrm{Ia}}$ & $45.27^{\mathrm{Ia}}$ & $3.99^{\mathrm{Ia}}$ & $11.35^{\text {Ia }}$ & $-30.72^{\text {Ic }}$ & $3.23^{\mathrm{Ia}}$ \\
\hline $\mathrm{S}$ & 0.260 & $75.2^{\text {la,c' }}$ & --- & $40.70^{\mathrm{la}}$ & $2.88^{16}$ & $14.12^{\mathrm{Ib}}$ & $-26.58^{\text {Id" }}$ & $3.76^{\mathrm{Ic}}$ \\
\hline \multicolumn{9}{|l|}{ Mangrove Estuary } \\
\hline$\overline{\mathrm{SS}}$ & 0.047 & $40.8^{\text {IIa }}$ & $0.71^{\text {Ia }}$ & $40.60^{\mathrm{Ia}}$ & 3.59 IIa & $11.35^{\text {Ia }}$ & $-28.95^{\text {IIa }}$ & $4.33^{\text {IIa }}$ \\
\hline $\mathrm{ST}$ & 0.050 & $40.1^{\text {IIa }}$ & $0.76^{\mathrm{Ia}}$ & $37.81^{\mathrm{Ia}}$ & $3.47^{\text {IIa }}$ & $10.92^{\text {Ia }}$ & $-29.15^{\text {IIb }}$ & $4.66^{\mathrm{IIb}}$ \\
\hline $\mathrm{F}$ & 0.095 & $28.5^{\mathrm{IIb}}$ & $0.78^{\mathrm{Ia}}$ & $43.60^{\mathrm{Ia}}$ & $3.91^{\text {IIa }}$ & $11.16^{\mathrm{Ia}}$ & $-28.43^{\text {IIc }}$ & $4.03^{\text {IIc }}$ \\
\hline $\mathrm{C}$ & 0.118 & $27.1^{\text {IIb }}$ & $0.72^{\mathrm{Ia}}$ & $43.22^{\mathrm{Ia}}$ & $3.17^{\text {IIa }}$ & $13.65^{\mathrm{IIb}}$ & $-27.20^{\text {IId }}$ & $3.71^{\text {IId }}$ \\
\hline $\mathrm{S}$ & 0.552 & $7.8^{11 \mathrm{c}}$ & ---- & $43.29^{\mathrm{la}}$ & $2.86^{\mathrm{Ilb}}$ & $15.17^{\mathrm{Ilc}}$ & $-25.17^{\text {IIe }}$ & $4.25^{\text {lla }}$ \\
\hline
\end{tabular}




\section{Differences Between Wetlands}

At the freshwater marsh site, sampled floc organic matter content ranged from $50 \%$ to $100 \%$ across all methods while soil $\% \mathrm{OM}$ ranged from $35 \%$ to $86 \%$ (Fig. 3a). At the mangrove estuary site, floc $\% \mathrm{OM}$ ranged from $24 \%$ to $43 \%$ and soil ranged from $5 \%$ to $14 \%$. Floc organic content was significantly different between wetland types $(\mathrm{p}<0.001 ;$ Table 2).

At the freshwater marsh site, floc $\mathrm{C}$ and $\mathrm{N}$ content ranged from $41.1 \%$ to $45.7 \%$ and $3.7 \%$ to $4.0 \%$, respectively, while soil $\mathrm{C}$ and $\mathrm{N}$ content ranged from $37.4 \%$ to $44.7 \%$ and $2.7 \%$ to $3.1 \%$, respectively (Table 2 ). Mangrove estuary floc $\% \mathrm{C}$ and $\% \mathrm{~N}$ ranged from $32.2 \%$ to $45.2 \%$ and $2.9 \%$ to $4.0 \%$, respectively, with soil $\mathrm{C}$ and $\mathrm{N}$ ranging from $42.1 \%$ to $44.1 \%$ and $2.8 \%$ to $2.9 \%$, respectively. There was no significant difference between wetland types or effect of collection method on floc $\% \mathrm{C}$. Floc $\% \mathrm{~N}$ was significantly different between marsh and estuary sites $(\mathrm{p}=0.023)$.

The mass ratio of carbon to nitrogen in floc samples at the freshwater marsh site ranged from 10.88 to 11.76 while SRS-2 soil C:N ranged from 13.98 to 14.33 (Fig. 3b). In the mangrove estuary, floc $\mathrm{C}: \mathrm{N}$ ranged from 10.75 to 14.19 with soil $\mathrm{C}: \mathrm{N}$ ranging from 14.42 to 15.80 . There was a significant effect of wetland type on floc $\mathrm{C}: \mathrm{N}$ but the effect of wetland type depended upon the type of collection method used $(\mathrm{p}<0.001$; Table 2$)$. Floc from the core method and wetland soil were the only samples to show significant $\mathrm{C}: \mathrm{N}$ ratio site differences $(\mathrm{p}<0.001$ and $\mathrm{p}=0.004$, respectively). 


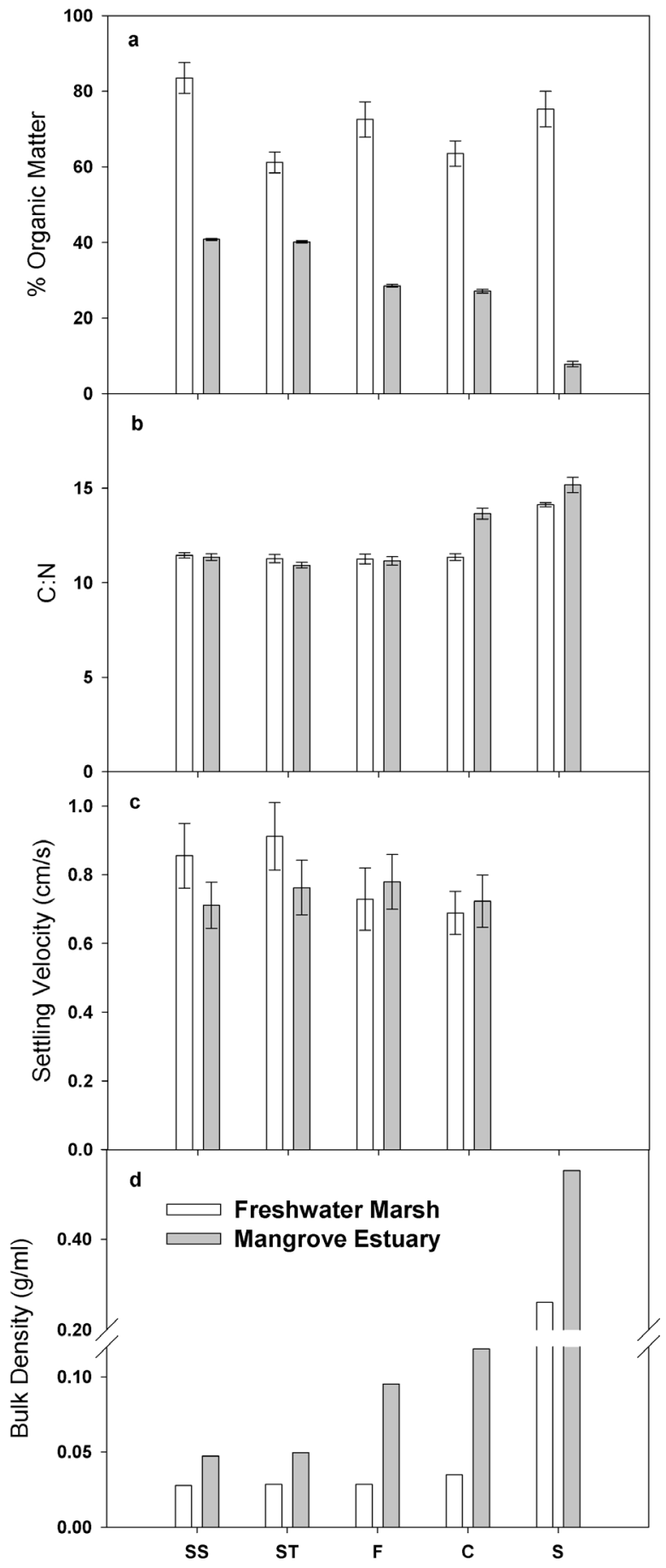

Figure 3. Organic matter content (panel a), C:N content ratio (panel b), settling velocity (panel c), and bulk density (panel d) of soil and floc samples collected at freshwater (SRS 2) and estuarine (TS 6) sites using different collection methods: $\mathrm{SS}=$ suction over soil; $\mathrm{ST}=$ suction over sheet; $\mathrm{F}=$ flocculator; $\mathrm{C}=$ core; $\mathrm{S}=$ soil. Error bars indicate triplicate sample standard error. 
Settling velocity (SV) of floc particles in the freshwater marsh ranged from 0.1 $\mathrm{cm} / \mathrm{s}$ to $3.5 \mathrm{~cm} / \mathrm{s}$ with a mean SV of $0.8 \mathrm{~cm} / \mathrm{s}$ (Fig. 3c). Mangrove estuary floc SV ranged from $0.2 \mathrm{~cm} / \mathrm{s}$ to $3.3 \mathrm{~cm} / \mathrm{s}$ with a mean of $0.7 \mathrm{~cm} / \mathrm{s}$. There was no significant difference in floc SV between wetland types (Table 2).

Freshwater marsh floc bulk density ranged from $0.028 \mathrm{~g} / \mathrm{ml}$ to $0.035 \mathrm{~g} / \mathrm{ml}$ while soil bulk density was $0.26 \mathrm{~g} / \mathrm{ml}$ (Fig. 3d). At the mangrove estuary site, floc bulk density ranged from $0.047 \mathrm{~g} / \mathrm{ml}$ to $0.12 \mathrm{~g} / \mathrm{ml}$ and soil bulk density was $0.55 \mathrm{~g} / \mathrm{ml}$.

Floc $\delta^{13} \mathrm{C}$ and $\delta^{15} \mathrm{~N}$ isotopic composition at the freshwater marsh ranged from $32.23 \%$ to $-30.65 \%$ and $3.19 \%$ to $4.25 \%$, respectively, while marsh soil $\delta^{13} \mathrm{C}$ and $\delta^{15} \mathrm{~N}$ ranged from $-26.64 \%$ o to -26.52 and $3.63 \%$ to $3.83 \%$, respectively (Fig. 4). Floc $\delta^{13} \mathrm{C}$ and $\delta^{15} \mathrm{~N}$ from the mangrove site ranged from $-29.17 \%$ to $-26.93 \%$ and $3.65 \%$ to $4.69 \%$, respectively, with TS/Ph-6 soil $\delta^{13} \mathrm{C}$ and $\delta^{15} \mathrm{~N}$ ranging from $-25.24 \%$ to $-25.10 \%$ and $4.24 \%$ to $4.27 \%$, respectively. There was a significant difference in observed $\delta^{13} \mathrm{C}$ and $\delta^{15} \mathrm{~N}$ between wetland types $(\mathrm{p}<0.001$; Table 2$)$. 


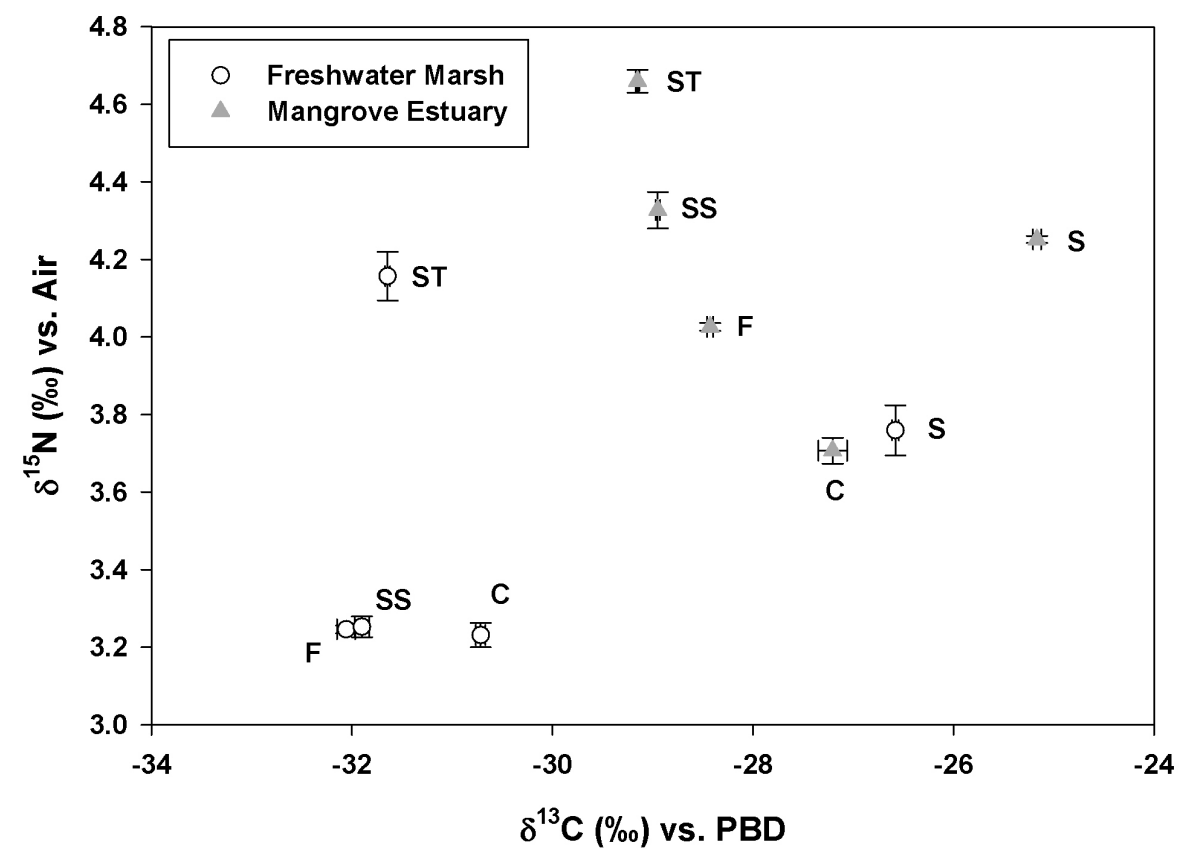

Figure 4. Isotopic composition of soil and floc samples collected at freshwater marsh (open circles) and mangrove estuary (grey triangles) sites using different methods: $\mathrm{SS}=$ suction off soil; $\mathrm{ST}=$ suction off sheet; $\mathrm{F}=$ flocculator; $\mathrm{C}=$ core; $\mathrm{S}=$ soil. Error bars indicate sample triplicate standard error.

\section{Ordination Results}

Sample Bray-Curtis similarity was plotted in two dimensional space using NMDS with a final stress of 0.01 (Fig. 5). Estuarine soil was least similar to all other sample types and formed an independent cluster up to a similarity threshold of 80. Estuarine floc clustered separately from freshwater floc and freshwater soil at a similarity of 90.

Freshwater floc was more similar to freshwater soil than to estuarine floc. Freshwater marsh floc was most similar between the ST and C methods, and these methods were the most distinct from freshwater soil. At the estuarine sampling site, floc collection via SS and ST were the most similar to each other and also the most dissimilar from estuarine soil. Estuarine $\mathrm{C}$ and $\mathrm{F}$ methods collected floc that was more similar to each other than to floc collected from other estuarine methods. In the estuarine mangrove site, both suction 
methods (SS and ST) collected floc samples that were most similar to freshwater marsh floc.

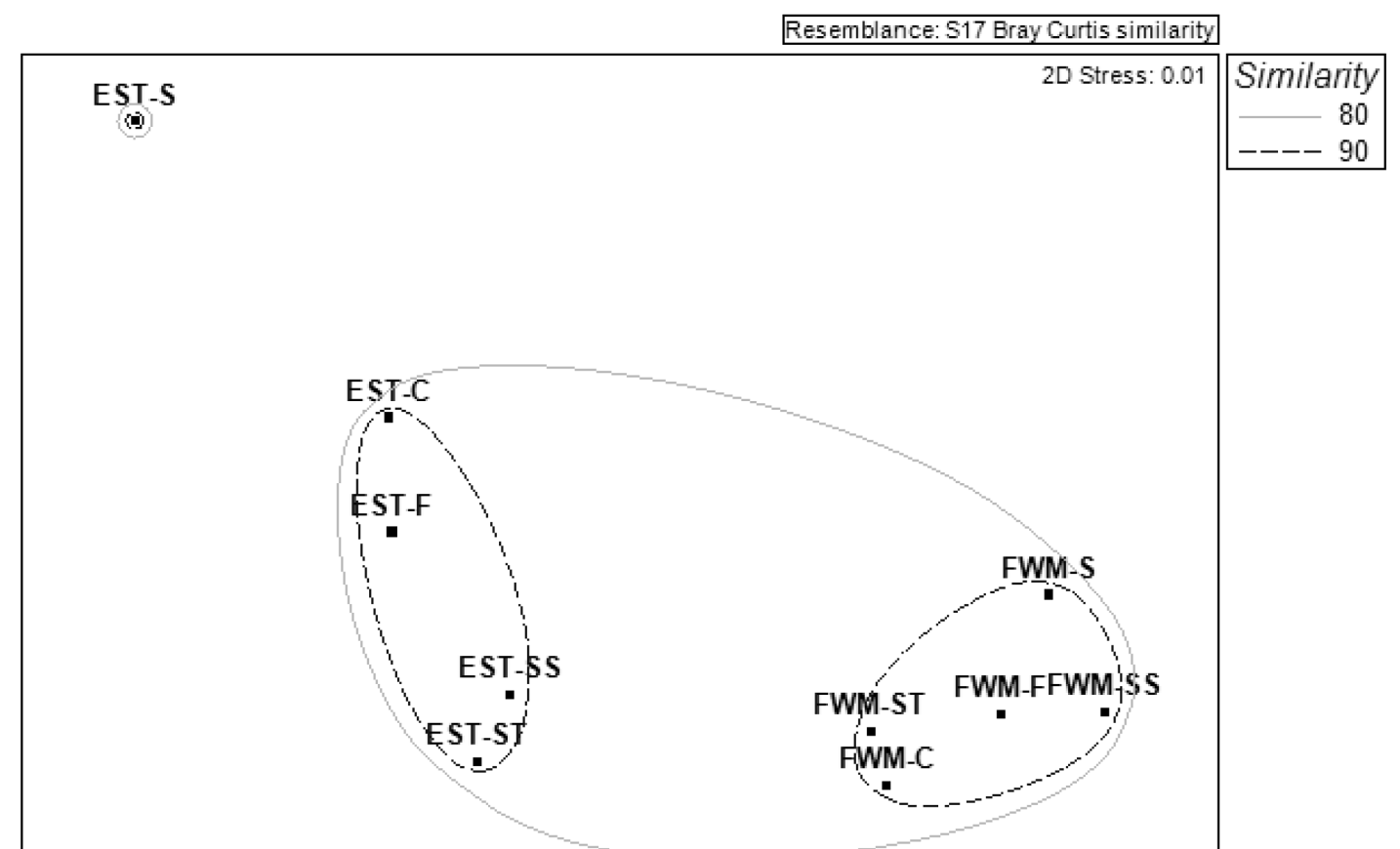

Figure 5. Non-metric multidimensional scaling (NMDS) ordination based on Bray-Curtis similarity of floc sampling methods: $\mathrm{SS}=$ suction over soil; $\mathrm{ST}=$ suction over sheet; $\mathrm{F}=$ flocculator; $\mathrm{C}=$ core; $\mathrm{S}=$ soil. Wetland type is denoted by FWM=freshwater marsh or EST=mangrove estuary. Clusters denote similarity thresholds of 80 (solid line) and 90 (dashed line).

\section{Discussion}

Flocculent detritus is ubiquitous in Everglades wetlands and plays an important role in shaping wetland ecosystem structure (Larsen et al. 2007) and function (Noe et al. 2003, Williams and Trexler 2006). I observed similar carbon content in floc and soils (40.6-45.3\% C) regardless of collection technique or wetland type. These values are similar carbon content of floc reported previously from Everglades freshwater marsh sites (40-42\% C; Wright and Reddy 2008, Troxler and Richards 2009). Although there was no difference in floc carbon quantity, I found that floc was higher in organic matter and 
nitrogen content, lower in density, and more depleted in ${ }^{13} \mathrm{C}$ than wetland soil. My estimates of floc bulk density $(0.028-0.173 \mathrm{~g} / \mathrm{ml})$ and $\mathrm{N}$ composition $(3.2-4.0 \% \mathrm{~N})$ were similar to other reports of Everglades floc density $(0.067-0.1 \mathrm{~g} / \mathrm{ml}$; Wright and Reddy 2008, Pisani et al. 2011) and N content (2.6-4\% N; Wright and Reddy 2008, Troxler and Richards 2009). Neto et al. (2006) reported evidence of diagenetic processing and decreasing carbon quality between floc and soil materials in freshwater and estuarine wetlands of the southern Everglades. Thus, while carbon quantity remains relatively static, carbon quality shows clear differences between detrital and soil pools in Everglades wetlands.

My range of floc settling velocities $(0.69-0.91 \mathrm{~cm} / \mathrm{s})$ was the same order of magnitude as other estimates for Everglades floc SV $(0.11 \mathrm{~cm} / \mathrm{s}$; Larsen and Harvey 2010). These researchers used a photographic method to calculate floc SV, which likely included a higher proportion of small floc particles compared with my visual method. Settling velocity is directly related to the size of spherical particles following Stokes' Law, and variations on Stokes' relationship have been empirically observed for natural sediments and flocs (Dietrich 1982, Gibbs 1985, Sternberg et al. 1999, Graham and Manning 2007, Larsen et al. 2009a). While my floc SV estimates may represent an overestimation of floc SV by excluding very small particles, my approach does provide an adequate comparison of floc SV between sampling methods and wetland location. I observed similar floc SV across collection methods and wetland type, suggesting that floc has a similar size and density distribution across the Everglades landscape and that sampling method does not discriminate floc particles by physical characteristics. Further, 
this suggests that flocculent material that has different organic matter content will still have similar advective properties across the Everglades landscape.

Does the Choice of Floc Sampling Method Matter?

I often found contrasting evidence that qualitative differences exist between floc sampling techniques. For example, I found no difference between methods in terms of floc carbon content, nitrogen content, or settling velocity (and, by extension, particle size). However, I consistently observed differences in floc stable isotope composition and organic matter content across collection methods. I also observed significant differences in these metrics between floc and soil. Therefore, it is most likely that observed differences in floc sampling methods are driven by differential capture of soil with the floc sample. If this capture of soil is an artifact of sample method, it would stand to reason that the ST (suction of floc over fiberglass sheet) method would provide the least amount of soil interference, as the fiberglass sheet would provide a physical barrier between the floc and soil during sample collection. Floc collected with the ST method at the freshwater marsh site did have decreased \%OM from other sample methods and the underlying soil; however this method did not appear to be solely responsible for any other significant physical or nutrient variation. Interestingly, the ST floc did possess isotopically enriched $\delta^{15} \mathrm{~N}$ signatures at both the freshwater marsh and mangrove estuary sites. Enriched $\delta^{15} \mathrm{~N}$ in floc from the ST method could point to increased nutrient exchange between floc, the water column, the microbial community and a decoupling of nutrient exchange between floc and underlying soil that is not present in the other collection methods. 
Bray-Curtis similarity among samples, plotted into two-dimensional space via NMDS, revealed that the ST method was consistently among the least similar from soil of the sampling methods at both wetland sites. Suction methods are highly effective at separating floc from soil at the mangrove estuary site because here floc overlies dense marl soils. Under these conditions, coring and advective traps appear to introduce soil fragments into the collected floc sample. In contrast, physical separation of floc from soil-either by a priori exclusion in the suction+sheet method or with a plunger in the core method - worked best at the freshwater marsh site wherein floc was more similar to the organic, peaty soils. At the freshwater marsh site, drying of the wetland surface during the dry season likely incorporates floc material into the soil matrix, contributing to the similarities observed here.

\section{Everglades Detritus as a Nutrient Vector}

In oligotrophic ecosystems, such as Everglades wetlands, nutrients are often found immobilized in organic forms and are quickly recycled following remineralization (Noe et al. 2001, Noe et al. 2003, Gaiser et al. 2004). Thus, mobile organic compartments of these ecosystems provide a means by which nutrients can be transported across the landscape. My data showed clear differences in detritus quality between upstream freshwater marsh and downstream estuarine wetlands. Freshwater floc was generally higher in organic matter and nitrogen content, and more deplete in ${ }^{13} \mathrm{C}$ and ${ }^{15} \mathrm{~N}$ than downstream mangrove floc. Neto et al. (2006) also observed decreasing floc $\mathrm{N}$ content and increasing floc $\mathrm{C}: \mathrm{N}$ along a transect from freshwater to estuarine sites in the Everglades. In addition, floc examined farther upstream than my study sites was higher 
in $\mathrm{N}$ and more deplete in ${ }^{15} \mathrm{~N}$ than my freshwater floc (Troxler and Richards 2009). A pattern of progressive sediment enrichment with downstream position has also been observed locally in Everglades estuaries, although this signal has been attributed in part to mixing of enriched marine-derived organic matter (Jaffé et al. 2001).

The isotopic composition of $\mathrm{C}$ and $\mathrm{N}$ is enriched as organic matter is transferred through the food web (Vander Zanden and Rasmussen 2001, McCutchan et al. 2003, Williams and Trexler 2006). McCutchan et al. (2003) identified an enrichment of +0.3 $1.3 \%$ for $\mathrm{C}$ and $+1.4-3.3 \%$ for $\mathrm{N}$ per trophic step depending on consumer diet and sampling protocol. The observed difference in floc $\delta^{13} \mathrm{C}$ values between freshwater marsh and estuarine wetlands in this study is in agreement with previous studies of floc carbon isotopic composition that link floc OM to local vegetation (Mead et al. 2005, Neto et al. 2006, Troxler and Richards 2009). Biogeochemical cycling of $\mathrm{N}$ also contributes to further enrichment of $\mathrm{N}$ isotopes to varying degrees depending on the particular $\mathrm{N}$ transformation, the proportion of source $\mathrm{N}$ consumed during the reaction, and external factors (Robinson 2001). For example, denitrification provides a pathway by which light ${ }^{14} \mathrm{~N}$ preferentially exits an ecosystem while heavier ${ }^{15} \mathrm{~N}$ is left behind. A pattern of increasing $\delta^{15} \mathrm{~N}$ of floc and other ecosystem components from upland, freshwater marsh to downstream coastal estuaries in the Everglades landscape has been observed in this study and by others (Jaffé et al. 2001, Neto et al. 2006, Wozniak et al. 2012), suggesting that downstream ecosystem components contain older, highly cycled N. Thus, while floc carbon appears highly dynamic, with continual inputs from local primary producers and loss from respiration, associated $\mathrm{N}$ and $\mathrm{P}$ are recycled and conserved in oligotrophic Everglades wetlands. Therefore, I propose that floc serves as an important vector of 
energy and nutrients as they are spiraled downstream through oligotrophic Everglades wetlands and future studies are needed to take a more detailed look at contributions of floc to ecosystem biogeochemistry.

\section{References}

Azam, F., T. Fenchel, J.G. Field, J.S. Gray, L.A. Meyer-Reil, and F. Thingstad. 1983. The ecological role of water-column microbes in the sea. Marine Ecology Progress Series 10: 257-263.

Boyer, J. N., J. W. Fourqurean, and R. D. Jones. 1999. Seasonal and long-term trends in the water quality of Florida Bay (1989-1997). Estuaries 22: 417-430.

D’Angelo, E.M. and K.R. Reddy. 1994. Diagenesis of organic matter in a wetland receiving hypereutrophic lake water: I. distribution of dissolved nutrients in the soil and water column. Journal of Environmental Quality 23(5): 928-936.

Davis, S. E. III, D. L. Childers, J. W. Day Jr., D. T. Rudnick, F. H. Sklar. 2001. Wetlandwater column exchanges of carbon, nitrogen, and phosphorus in a southern Everglades dwarf mangrove. Estuaries 24(4): 610-622.

Dietrich, W.E. 1982. Settling velocity of natural particles. Water Resources Research 18(6): 1615-1626.

Droppo, I.G., G.G. Leppard, D.T. Flannigan, and S.N. Liss. 1997. The freshwater floc: a function relationship of water and organic and inorganic floc constituents affecting suspended sediment properties. Water, Air, and Soil Pollution 99: 43-54.

Droppo, I.G. 2001. Rethinking what contitues suspended sediment. Hydrological Processes 15: 1551-1564.

Duever, M.J., J.F. Meeder, L.C. Meeder, and J.M. McCollom. 1994. The climate of South Florida and its role in shaping the Everglades ecosystem. In: [S.M. Davis and J.C. Ogden, eds.] Everglades: The Ecosystem and its Restoration, pp. 225-248, St. Lucie Press, Delray Beach, FL.

Ewe, SM.L., E.E. Gaiser, D.L. Childers, D. Iwaniec, V.H. Rivera-Monroy, R.R. Twilley. 2006. Spatial and temporal patterns of aboveground net primary productivity (ANPP) along two freshwater-estuarine transects in the Florida Coastal Everglades.

Hydrobiologia 560: 459-474. 
Gaiser, E. E., L. J. Scinto, J. H. Richards, K. Jayachandran, D. L. Childers, J. C. Trexler, and R. D. Jones. 2004. Phosphorus in periphyton mats provides the best metric for detecting low-level P enrichment in an oligotrophic wetland. Water Research 38: 507516.

Gaiser, E.E., J.C. Trexler, J.H. Richards, D.L. Childers, D. Lee, A.L. Edwards, L.J. Scinto, K. Jayachandran, G.B. Noe, and R.D. Jones. 2005. Cascading ecological effects of low-level phosphorus enrichment in the Florida Everglades. Journal of Environmental Quality 34: 717-723.

Gibbs, R.J. 1985. Estuarine flocs: their size, settling velocity, and density. Journal of Geophysical Research 90: 3249-3251.

Graham, G.W. and A.J. Manning. 2007. Floc size and settling velocity within a Spartina anglica canopy. Continental Shelf Science 27: 1060-1079.

Hafner, S.D. and W.J. Jewell. 2006. Predicting nitrogen and phosphorus removal in wetlands due to detritus accumulation: a simple mechanistic model. Ecological Engineering 27: 13-21.

Hornung, J.P. and A. L. Foote. 2008. Comparing dietary preference of Bufflehead ducklings in Western Canada through gut content and stable isotope analysis. Aquatic Ecology 42: 61-70.

Jaffé R., R. Mead, M.E. Hernandez, M.C. Peralba, O.A. DiGuida. 2001. Origin and transport of sedimentary organic matter in two subtropical estuaries: a comparative, biomarker-based study. Organic Geochemistry 32: 507-526.

Kadlec, R.H. and S. Wallace. 2009. Treatment Wetlands, 2nd ed. CRC Press, Boca Raton, FL.

Larsen, L.G. and J.W. Harvey. 2010. How vegetation and sediment transport feedbacks drive landscape change in the Everglades and wetlands worldwide. American Naturalist 176(3): E66-E79.

Larsen, L.G., J.W. Harvey, and J.P. Crimaldi. 2007. A delicate balance: ecohydrological feedbacks governing landscape morphology in a lotic peatland. Ecological Monographs 77(4): 591-614.

Larsen, L.G., J.W. Harvey, and J.P. Crimaldi. 2009a. Morphologic and transport properties of natural organic floc. Water Resources Research 45: W01410.

Larsen, L.G., J.W. Harvey, G.B. Noe, and J.P. Crimaldi. 2009b. Predicting organic floc transport dynamics in shallow aquatic ecosystems: insights from the field, the laboratory, and numerical modeling. Water Resources Research 45: W01411. 
Light, S. S. and J. W. Dineen. 1994. Water control in the Everglades: a historical perspective. In: [S.M. Davis and J.C. Ogden, eds.] Everglades: The Ecosystem and its Restoration. St. Lucie Press, Delray Beach, FL.

Liss, S.N., I.G. Droppo, D.T. Flannigan, and G.G. Leppard. 1996. Floc architecture in wastewater and natural riverine systems. Environmental Science and Technology 30: 680-686.

Mead R., Y. Xu, J. Chong, R. Jaffé. 2005. Sediment and soil organic matter source assessment as revealed by the molecular distribution and carbon isotopic composition of n-alkanes. Organic Geochemistry 36: 363-370.

McCutchan, J.H. Jr., W.M. Lewis Jr., C. Kendall, C.G. McGrath. 2003. Variation in trophic shift for stable isotope ratios of carbon, nitrogen, and sulfur. Oikos 102(2): 378390.

Neto R.R., R.N. Mead, J.W. Louda, R. Jaffé. 2006. Organic biogeochemistry of detrital flocculent material (floc) in a subtropical, coastal wetland. Biogeochemistry 77: 283-304.

Noe, G.B., D.L. Childers, R.D. Jones. 2001. Phosphorus biogeochemistry and the impact of phosphorus enrichment: why is the Everglades so unique? Ecosystems 4: 603-624.

Noe, G.B., D.L. Childers, A.L. Edwards, E. Gaiser, K. Jayachandran, D. Lee, J. Meeder, J. Richards, L.J. Scinto, J. C. Trexler, and R.D. Jones. 2002. Short-term changes in phosphorus storage in an oligotrophic Everglades wetland ecosystem receiving experimental nutrient enrichment. Biogeochemistry 59: 239-267.

Noe, G.B., L.J. Scinto, J. Taylor, D.L. Childers, and R.D. Jones. 2003. Phosphorus cycling and partitioning in an oligotrophic Everglades wetland ecosystem: a radioisotope tracing study. Freshwater Biology 48: 1993-2008.

Noe, G.B., J.W. Harvey, R.W. Schaffranek, L.G. Larsen. 2010. Controls of suspended sediment concentration, nutrient content, and transport in a subtropical wetland. Wetlands 30: $39-54$.

Odum, E.P. 1969. The strategy of ecosystem development. Science 164: 596-604.

Odum, W.E. and E.J. Heald. 1975. The detritus-based food web of an estuarine community. In: [L.E. Cronin, ed.] Estuarine Research, Vol. 1. Academic Press, New York.

Pisani, O., Y. Yamashita, and R. Jaffé. 2011. Photo-dissolution of flocculent, detrital material in aquatic environments: contributions to the dissolved organic matter pool. Water Research 45: 3836-3844. 
Robinson, D. 2001. $\delta^{15} \mathrm{~N}$ as an integrator of the nitrogen cycle. Trends in Ecology and Evolution 16(3): 153-162.

Schoenberg, S. 1988. Microcustacean community structure and biomass in marsh and lake habitats of the Okefenokee Swamp: seasonal dynamics and responses to resource manipulations. Ecography 11: 8-18.

Sternberg, R.W., I. Berhane, and A.S. Ogston. 1999. Measurement of size and settling velocity of suspended aggregates on the northern California continental shelf. Marine Geology 154: 43-53.

Sutula, M. A., B. C. Perez, E. Reyes, D. L. Childers, S. Davis, J. W. Day Jr., D. Rudnick, F. Sklar. 2003. Factors affecting the spatial and temporal variability in material exchange between the southern Everglades wetlands and Florida Bay (USA). Estuarine, Coastal and Shelf Science 57: 757-781.

Teal, J.M. 1962. Energy flow in the salt marsh ecosystem of Georgia. Ecology 43(4): 614-624.

Troxler, T.G. and J.H. Richards. 2009. $\delta 13 \mathrm{C}, \delta 15 \mathrm{~N}$, carbon, nitrogen, and phosphorus as indicators of plant ecophysiology and organic matter pathways in Everglades deep slough, Florida, USA. Aquatic Botany 90(2): 129-136.

Vander Zanden, M.J. and J.B. Rasmussen. 2001. Variation in $\delta 15 \mathrm{~N}$ and $\delta 13 \mathrm{C}$ trophic fractionation: implications for aquatic food web studies. Limnology and Oceanography 46: 2061-2066.

Vitousek, P. 1982. Nutrient cycling and nutrient use efficiency. American Naturalist 119(4): 553-572.

Vitousek, P.M. and R.L. Sanford, Jr. 1986. Nutrient cycling in moist tropical forest. Annual Review of Ecology and Systematics 17: 137-167.

Wallace, J.B., S.L. Eggert, J.L. Meyer, and J.R. Webster. 1997. Multiple trophic levels of a forest stream linked to terrestrial litter inputs. Science 4(5322): 102-104.

Williams, A.J. and J.C. Trexler. 2006. A preliminary analysis of the correlation of foodweb characteristics with hydrology and nutrient gradients in the southern Everglades. Hydrobiologia 569: 493-504.

Wong, K.B. and R.H. Piedrahita. 2000. Settling velocity characterization of aquacultural solids. Aquacultural Engineering 21: 233-246. 
Wood, A. 2005. Dynamics of detrital particulate organic material in the ridge and slough landscape of the Everglades. Master's Thesis, Florida International University.

Wozniak, J.R., W.T. Anderson, D.L. Childers, E.E. Gaiser, C.J. Madden, and D.T. Rudnick. 2012. Potential N processing by southern Everglades freshwater marshes: are Everglades marshes passive conduits for nitrogen? Estuarine, Coastal, and Shelf Science 96: 60-68.

Wright, A.L. and K.R. Reddy. 2008. Catabolic diversity of periphyton and detritus microbial communities in a subtropical wetland. Biogeochemistry 89: 199-207.

Wright, A.L., K.R. Reddy, and S. Newman. 2009. Microbial indicators of eutropication in Everglades wetlands. Soil Science Society of America Journal 73(5): 1597-1603. 
IV. Examining Flocculent Detritus Transport in an Estuarine Wetland Using a Sediment Tracing Technique

Introduction

Over the last 100 years, the Florida Everglades have undergone extensive drainage and compartmentalization that have reduced freshwater flows to downstream estuaries (Light and Dineen 1994, Sklar et al. 2005, McVoy 2011). The diminished freshwater delivery to Everglades estuaries has resulted in increased salinities in the coastal zone and landward transgression of salt-tolerant vegetation communities (Ross et al. 2000, Gaiser et al. 2006). The Comprehensive Everglades Restoration Plan (CERP; www.evergladesplan.org) includes plans to restore freshwater delivery to Taylor Slough, a shallow drainage basin in the southern Everglades, ultimately resulting in increased freshwater flow to the downstream Taylor River estuary (Fig. 1). With successful restoration, Taylor River should experience hydrologic conditions that more closely approximate historical patterns. It is therefore important to understand how ecosystem function in Taylor River interacts with freshwater inputs in order to guide restoration efforts. In this study, I examine Taylor River detrital transport dynamics within the context of current wet/dry season hydrology. 


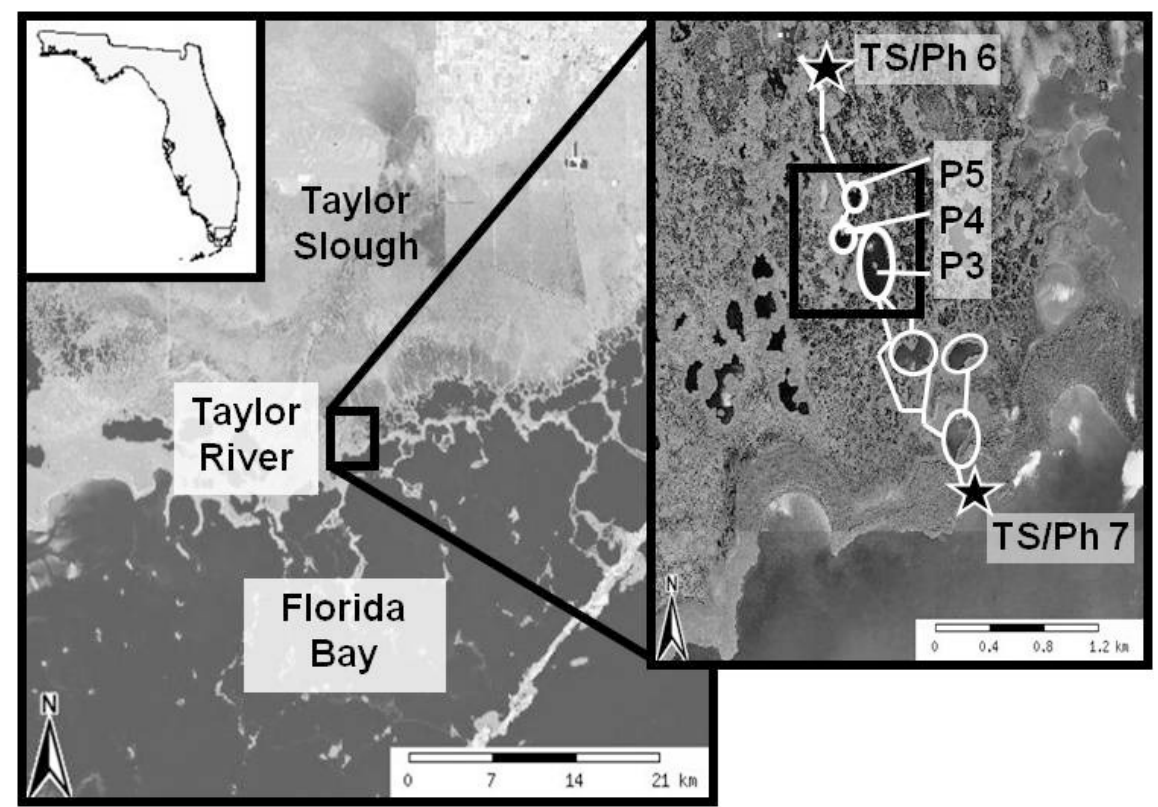

Figure 1. Location of the pond/creek sites (P3-5 = ponds 3 through 5 , respectively) used in this study and their context within the Taylor Slough watershed. FCE-LTER sites TS/Ph 6 and TS/Ph 7 are located along Taylor River (inset; outlined in white) both upstream and downstream of the study ponds.

A surface layer of unconsolidated, flocculated detritus ("floc") is a common feature in Everglades marshes and estuaries (Noe et al. 2002, Mead et al. 2005, Neto et al. 2006, Williams and Trexler 2006, Troxler and Richards 2009, Larsen et al. 2009, Pisani et al. 2010) and appears to form the base of Everglades food webs (Williams and Trexler 2006, Belicka et al. 2012). These labile, organic pools increase in importance in oligotrophic ecosystems because nutrients trapped in organic forms are quickly recycled from old to new biomass (sensu Odum 1969, Vitousek 1982, Vitousek and Sanford 1986). Nutrients therefore spend little time in inorganic forms in oligotrophic ecosystems, such as the extremely phosphorus (P)-deficient Taylor River estuary (Noe et al. 2001, Gaiser et al. 2004, Gaiser et al. 2005). Several studies have linked Everglades floc organic matter (OM) to local wetland primary producers (Jaffé et al. 2001, Mead et al. 2005, Neto et al. 2006), including periphyton (Noe et al. 2002, Noe et al. 2003), a 
complex associate of algae, bacteria, and fungi abundant throughout the Everglades, and submerged aquatic vegetation, particularly free-floating bladderwort (Utricularia spp.; Troxler and Richards 2009).

Floc is a highly porous matrix of inorganic and organic constituents (Liss 1996, Droppo et al. 1997) that is particularly susceptible to aqueous transport (Droppo 2001). Hydrologic redistribution of floc and sediments has been shown to be a primary driver of landscape patterning in wetlands (Larsen and Harvey 2010), particularly the Everglades (Larsen et al. 2007). Furthermore, wetland-derived detrital OM is an important energy subsidy to estuaries (Teal 1962, Odum 1968, Odum and Heald 1975, Nixon 1980, Childers et al. 2000) and appears to play a vital role in the water column metabolism of Taylor River (Koch et al. 2012).

The existing seasonal and inter-annual variability of water flow in Taylor River affords the opportunity to investigate relationships between ecosystem function and hydrologic forcing. In this study, I used a sediment tracing technique to estimate floc transport in Taylor River during the estuarine wet and dry seasons. I hypothesized that floc tracer transport would be greatest during wet season as a result of increased water velocities entraining floc particles. I further hypothesized that pond storage of floc tracer would be greatest during the low-flow and high water residence time of the estuarine dry season. 
Methods

Site Description

Taylor Slough is one of two major drainage basins within Everglades National Park, Florida, USA (Fig 1). Historically water entered this watershed largely via local precipitation, but the water budget now includes managed canal inputs (Light and Dineen 1994, Childers et al. 2006). Taylor River, the estuarine portion of Taylor Slough, is one of the most important hydrologic connections between Taylor Slough freshwater marshes and northeastern Florida Bay (Davis et al. 2001, Sutula et al. 2003) and is characterized by a series of ponds connected by creeks that meander through extensive scrub mangrove wetlands. I estimated detrital transport in three centrally-located Taylor River pond/creek pairs: Pond $3\left(4.69 \mathrm{ha}, 25.2035^{\circ} \mathrm{N}, 80.6437^{\circ} \mathrm{W}\right)$, Pond $4\left(0.66 \mathrm{ha}, 25.2057^{\circ} \mathrm{N}, 80.6464^{\circ} \mathrm{W}\right)$, and Pond $5\left(0.60 \mathrm{ha}, 25.2075^{\circ} \mathrm{N}, 80.6453^{\circ} \mathrm{W}\right.$; Fig. 1). These study sites are located between Florida Coastal Everglades Long-Term Ecological Research Program (FCE LTER) sites TS/Ph 6 (upstream) and TS/Ph 7 (downstream; Fig. 1).

South Florida's subtropical climate is defined by a climatological wet season from June through November and a dry season from December through May (Duever et al. 1994). However, Taylor River responds to these seasons after a time lag that reflects the time delay taken for changes in seasonal water delivery to reach the downstream estuary (Koch et al. 2012). This estuarine system experiences negligible astronomical tides and has minimal topographic relief. Taylor River drains a mangrove-dominated basin that is separated from Florida Bay by Buttonwood Ridge, a higher elevation depositional berm. Surface water exchange between Taylor River and Florida Bay occurs where the river flows through Buttonwood Ridge. Freshwater flows down Taylor River and into Florida 
Bay during the wet season, while wind-forced excursions of higher salinity Florida Bay water move upriver during the dry season (Davis et al. 2001). As a result, there are large seasonal differences in water residence time and system salinity in Taylor River (Childers et al. 2006, Koch et al. 2012).

\section{Sediment Tracer}

I estimated downstream floc flux in Taylor River using a synthetic, paramagnetic sediment tracer that was manufactured to have the same size distribution and buoyancy characteristics of natural Everglades floc (manufactured by Partrac Ltd, Glasgow, Scotland, UK). I deployed the tracer on the bottom of the creek channels, but it was critical that no tracer be released into the water column during deployment as this "stray" tracer might be dispersed into the water column and contaminate downstream collectors. To accomplish a "clean" deployment, I placed a slurry of tracer [of known weight] into $37 \times 26 \times 14 \mathrm{~cm}(\mathrm{LxWxH})$ plastic containers, added 4-5 small rocks for weight, and froze the containers at $-80^{\circ} \mathrm{C}$. The containers of tracer were kept frozen during transportation to field sites using dry ice. Once on site, the frozen blocks of tracer and rocks were removed from the containers and placed on the river bottom, and as the blocks thawed the tracer was released at the bottoms of the creeks.

I established tracer capture points by suspending cylindrical magnets vertically in the water column with the bottom of the magnet touching the creek bottom. Floc tracer particles were captured if they passed within $2.5 \mathrm{~cm}$ of the magnet. Each magnet was placed inside a vinyl tube sheath, which did not dampen the capture field, to facilitate separation of tracer from the magnet after retrieval. I established two transects 
perpendicular to the river channel—one upstream and one downstream of the tracer release point (Fig. 2). Prior to tracer release, I placed two magnets along the upstream transect ("UR" and "UL") and three magnets along the downstream transect ("DR", "DM", and "DL"). Nine additional magnets were placed in the pond immediately downstream of the tracer release point near the inlet (named "1" through "9") and one additional magnet was positioned at the pond outlet ("OUT"; Fig. 2). This network of magnets was designed to estimate tracer transport both upstream and downstream within the creek as well as the delta-like pattern of tracer deposition at the pond inflow.

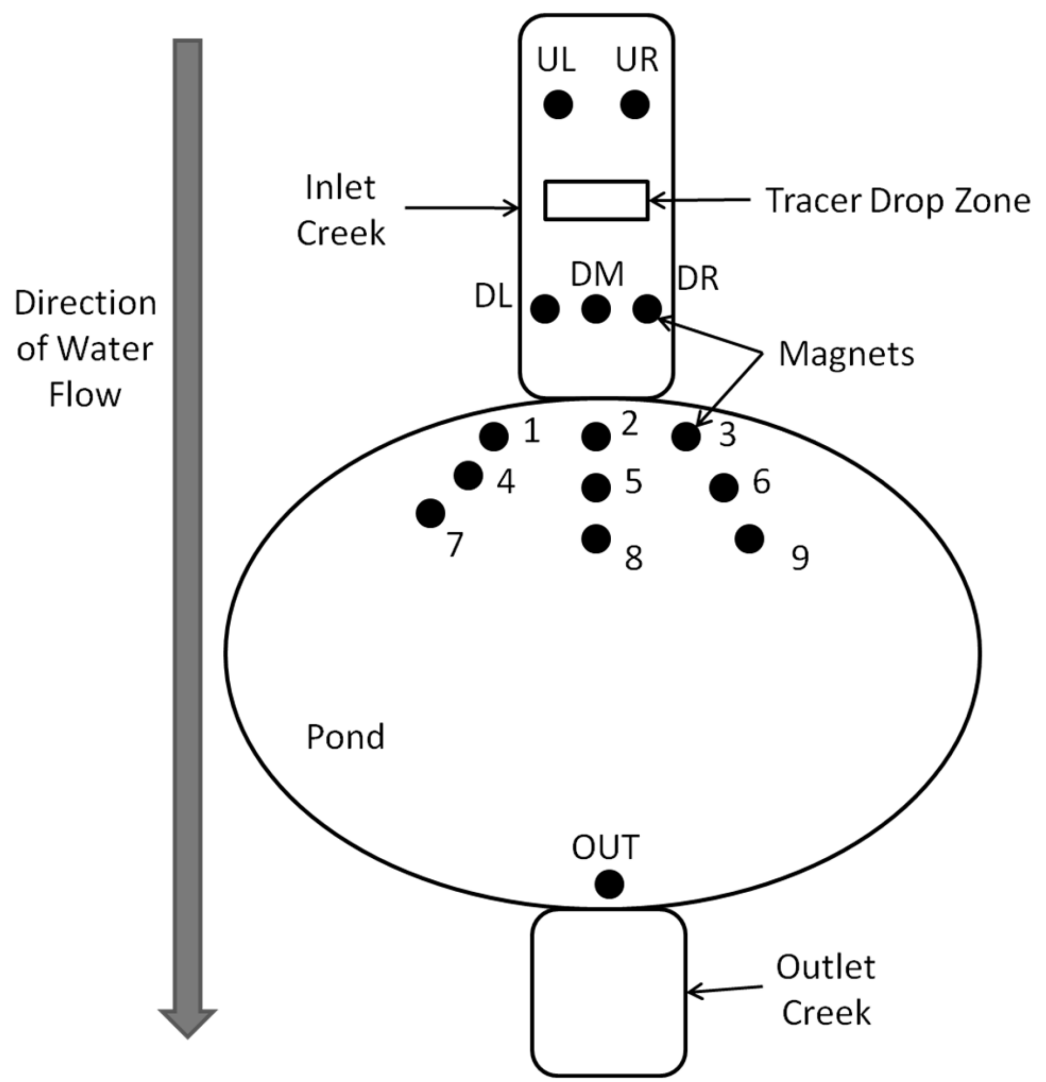

Figure 2. Schematic of the floc tracer experimental setup showing a generalized, top-down view of a Taylor River pond with inlet and outlet creeks. Floc tracer was released within the inlet creek while magnets were positioned upstream and downstream of the tracer drop zone. 
I released the floc sediment tracer in December 2009 (estuarine "wet" season) and repeated the experiment in July 2010 (estuarine "dry" season). The tracer was allowed to freely move through the creek channel via advection for approximately one week (wet season $=8$ days, dry season $=10$ days). I then retrieved the magnets with their captured tracer from the river channel and transported them back to the laboratory. In the lab, I removed the vinyl sheaths from the magnets so that the tracer could be easily rinsed into individual, pre-weighed drying trays and dried at $60^{\circ} \mathrm{C}$ for one week. Refer to Black et al. (2007) for a detailed discussion of the use of magnetic sediment tracer methodology.

\section{Estimating Tracer Flux}

I determined the flux of tracer by estimating the amount of tracer passing through the cross-sectional area of the river channel at the upstream and downstream transects according to:

$$
\mathrm{F}_{\mathrm{x}}=\left(\left(\mathrm{M}_{\mathrm{x}} / 5 \mathrm{~cm}\right) * \mathrm{~W}_{\mathrm{x}}\right) / \mathrm{t}
$$

where $F_{x}$ is the flux of tracer passing through transect $x, M_{x}$ is the mean $\%$ mass of tracer collected on the magnets of transect $\mathrm{x}$ relative to the dry mass of tracer deployed at that site, $\mathrm{W}_{\mathrm{x}}$ is the width in $\mathrm{cm}$ of the creek channel at transect $\mathrm{x}$, and $\mathrm{t}$ is the total duration in days from tracer release to removal of the collection magnets. I repeated this process for the upstream, downstream, and pond outlet at each site and used the $95 \%$ confidence interval of $\mathrm{M}_{\mathrm{x}}$ to estimate error associated with each $\mathrm{F}_{\mathrm{x}}$. Pond tracer storage was calculated as the difference between the fluxes measured at the pond inlet and pond outlet. 


\section{Tracer Velocity}

I estimated seasonal mean tracer velocity $\left(\mathrm{V}_{\mathrm{s}}\right)$ by weighting velocity by tracer weight according to:

$$
\mathrm{V}_{\mathrm{s}}=\Sigma\left[\mathrm{m}_{\mathrm{i}} *\left(\mathrm{~d}_{\mathrm{i}} / \mathrm{t}_{\mathrm{s}}\right)\right] / \Sigma\left(\mathrm{m}_{\mathrm{i}}\right)
$$

where $\mathrm{m}_{\mathrm{i}}$ is the $\%$ of injected tracer mass on magnet $i, \mathrm{~d}_{\mathrm{i}}$ is the distance in meters of magnet $i$ from the initial tracer drop site, and $\mathrm{t}_{\mathrm{s}}$ is the total study travel time in days for season $s$. I measured magnet distance from satellite imagery using Google Earth.

\section{Surface Water Variables}

I obtained Taylor River surface water discharge and water level data from U.S. Geologic Survey (USGS) gauging stations located near FCE LTER sites TS/Ph 6 and TS/Ph 7 (Fig. 1). These data are publically available through the USGS South Florida Information Access website (http://sofia.usgs.gov). I calculated Taylor River surface water velocity at both gauges from January 1, 2009 through September 30, 2010 according to:

$$
\mathrm{V}=\mathrm{Q} / \mathrm{d} / \mathrm{W}
$$

where $\mathrm{V}$ is water velocity, $\mathrm{Q}$ is discharge, $\mathrm{d}$ is water depth, and $\mathrm{w}$ is the cross-sectional width of the creek channel. I assumed a channel width of approximately 1 meter based on personal observation and approximation via satellite imagery using Google Earth. It was necessary to adjust USGS stage data because these data are published relative to the North American Vertical Datum of 1988 (NAVD88) and not relative to the creek bed. I estimated creek depth by assuming that deviations from mean NAVD88 stage correspond to equal deviations from a mean water depth of 1 meter. This depth approximation has 
been previously employed in Taylor River by Koch et al. (2012). Lastly, I estimated water velocity and depth at my study sites, located in the middle reach of Taylor River, by taking the arithmetic mean between water velocities at upstream and downstream gauges.

Statistical Analyses

Seasonal differences in Taylor River discharge, water velocity, and water depth were assessed using parametric Student's $t$-tests or nonparametric Mann-Whitney Rank Sum tests (for data that violate the assumptions of parametric statistical analyses). Seasonal differences in \% tracer captured by each magnet were examined using nonparametric Wilcoxon Signed Rank tests because neither the original data nor transformations thereof met the assumptions of normality and homoscedasticity required for parametric analyses. I used \% mass of tracer for all comparisons in this paper instead of dry mass because captured tracer weight was proportional to the varying mass of tracer injected at each site. I constructed interpolated contour plots using SigmaPlot 11.0 in order to estimate floc tracer dispersion near the inlet of each pond. An $\alpha=0.05$ was used to determine significance for all analyses used in this study.

Results

Hydrologic Variables

Taylor River mean daily discharge rates varied seasonally during the 2009-2010 record, with upstream discharge ranging from $-0.63 \mathrm{~m}^{3} / \mathrm{s}$ to $+0.92 \mathrm{~m}^{3} / \mathrm{s}$ and downstream discharge ranging from $-3.90 \mathrm{~m}^{3} / \mathrm{s}$ to $+6.02 \mathrm{~m}^{3} / \mathrm{s}$ (Fig. 3a). Estimated water velocity for 
the middle reach of Taylor River, where my study sites are located, varied seasonally from a maximum upstream velocity of $-2.06 \mathrm{~m} / \mathrm{s}$ to a maximum downstream velocity of $3.13 \mathrm{~m} / \mathrm{s}$ (Fig. 3b). Similarly, water depth ranged from $0.67 \mathrm{~m}$ to $1.33 \mathrm{~m}$ over the entire 2009-2010 record.

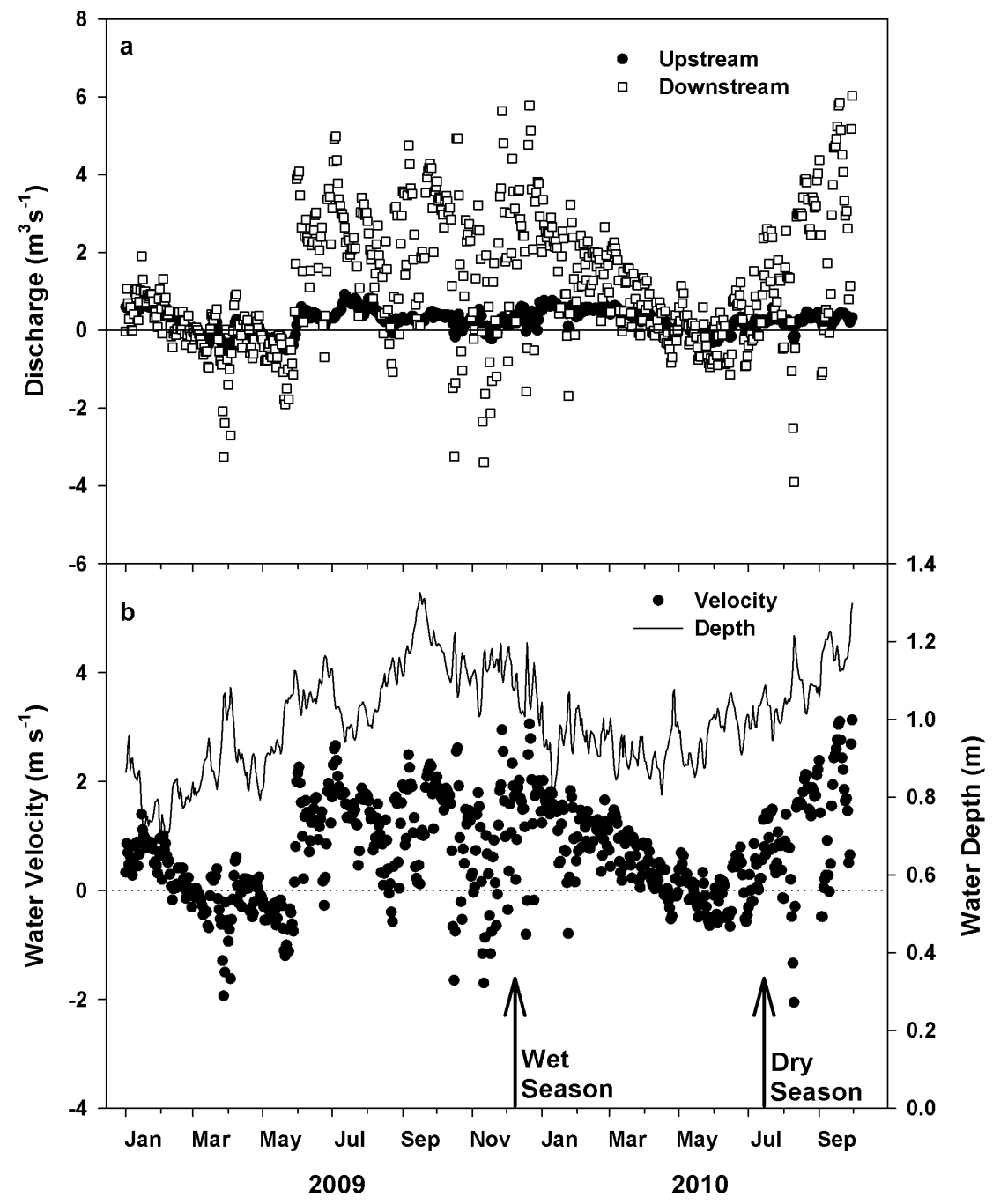

Figure 3. Mean daily surface water discharge from USGS gauges located upstream (panel a; black circles) and downstream (open squares) from my study sites during 2009 and 2010 as well as estimated daily water velocity (panel b; black circles) and water depth (black line) at my study sites. Negative values indicate upstream water movement. Arrows indicate timing of floc tracer experiments. 
During the floc tracer study, median daily upstream discharge was significantly lower during wet season sampling $\left(0.19 \mathrm{~m}^{3} / \mathrm{s}, \mathrm{n}=8\right)$ than during dry season sampling $\left(0.35 \mathrm{~m}^{3} / \mathrm{s}, \mathrm{n}=10\right.$; Mann-Whitney $U=12.00, \mathrm{p}=0.015$; Table 1$)$. However, mean daily downstream discharge was not significantly different between wet $\left(2.33 \mathrm{~m}^{3} / \mathrm{s}\right)$ and dry $\left(1.23 \mathrm{~m}^{3} / \mathrm{s}\right)$ season sampling (Student's $\left.t=2.04, \mathrm{p}=0.058\right)$. Median water velocity during the wet season $(1.32 \mathrm{~m} / \mathrm{s})$ was not significantly different from the dry season $(0.80 \mathrm{~m} / \mathrm{s}$; $\mathrm{U}=25.00, \mathrm{p}=0.198)$, although mean depth was found to differ between wet $(1.12 \mathrm{~m})$ and dry $(0.99 \mathrm{~m})$ sampling events $(t=7.682, \mathrm{p}<0.001)$.

Table 1. Differences in mean Taylor River hydrologic variables, estimated tracer velocity, and estimated pond storage between seasonal sampling events. Bold text indicates significant differences at $\alpha=0.05$.

\begin{tabular}{crrrr}
\hline & $\begin{array}{c}\text { Wet Season } \\
(\mathrm{n}=8 \text { days })\end{array}$ & $\begin{array}{c}\text { Dry Season } \\
(\mathrm{n}=10 \text { days })\end{array}$ & $\begin{array}{r}\text { Difference } \\
\text { (wet - dry) }\end{array}$ & P-value \\
\hline $\begin{array}{c}\text { Upstream } \\
\text { Discharge }\left(\mathrm{m}^{3} / \mathrm{s}\right)\end{array}$ & 0.23 & 0.38 & $\mathbf{- 0 . 1 5}$ & $\mathbf{0 . 0 1 5 ^ { * * }}$ \\
$\begin{array}{c}\text { Downstream } \\
\text { Discharge }\left(\mathrm{m}^{3} / \mathrm{s}\right)\end{array}$ & 2.33 & 1.23 & 1.10 & $0.058^{*}$ \\
Water Velocity $(\mathrm{m} / \mathrm{s})$ & 1.26 & 0.81 & 0.45 & $0.20^{* *}$ \\
Water Depth (m) & 1.12 & 0.99 & $\mathbf{0 . 1 3}$ & $<\mathbf{0 . 0 0 1}$ \\
Tracer & 1.55 & 1.63 & -0.08 & $\mathrm{n} / \mathrm{a}$ \\
Velocity (m/day) & & & &
\end{tabular}

\section{Tracer Capture}

As expected, I recovered the greatest proportion of tracer along the transect of magnets placed immediately downstream of the tracer drop zone (magnets DL, DM, and DR; Fig. 4). The DM magnet, positioned in the center of the downstream creek transect, most frequently captured the most tracer across all samplings. Unlike other sites, the maximum tracer capture in Pond 5 during the dry season was at magnet 3, located within the downstream pond, rather than at the immediate downstream creek transect. In Pond 
3 , the proportion of tracer recovered during the wet season was significantly greater than that recovered in the dry season (Wilcoxon signed rank test $\mathrm{p}=0.001$ ). I observed no significant difference in seasonal tracer capture in Pond $4(\mathrm{p}=0.934)$, Pond $5(\mathrm{p}=0.217)$, or when data were combined across all ponds $(\mathrm{p}=0.468)$.

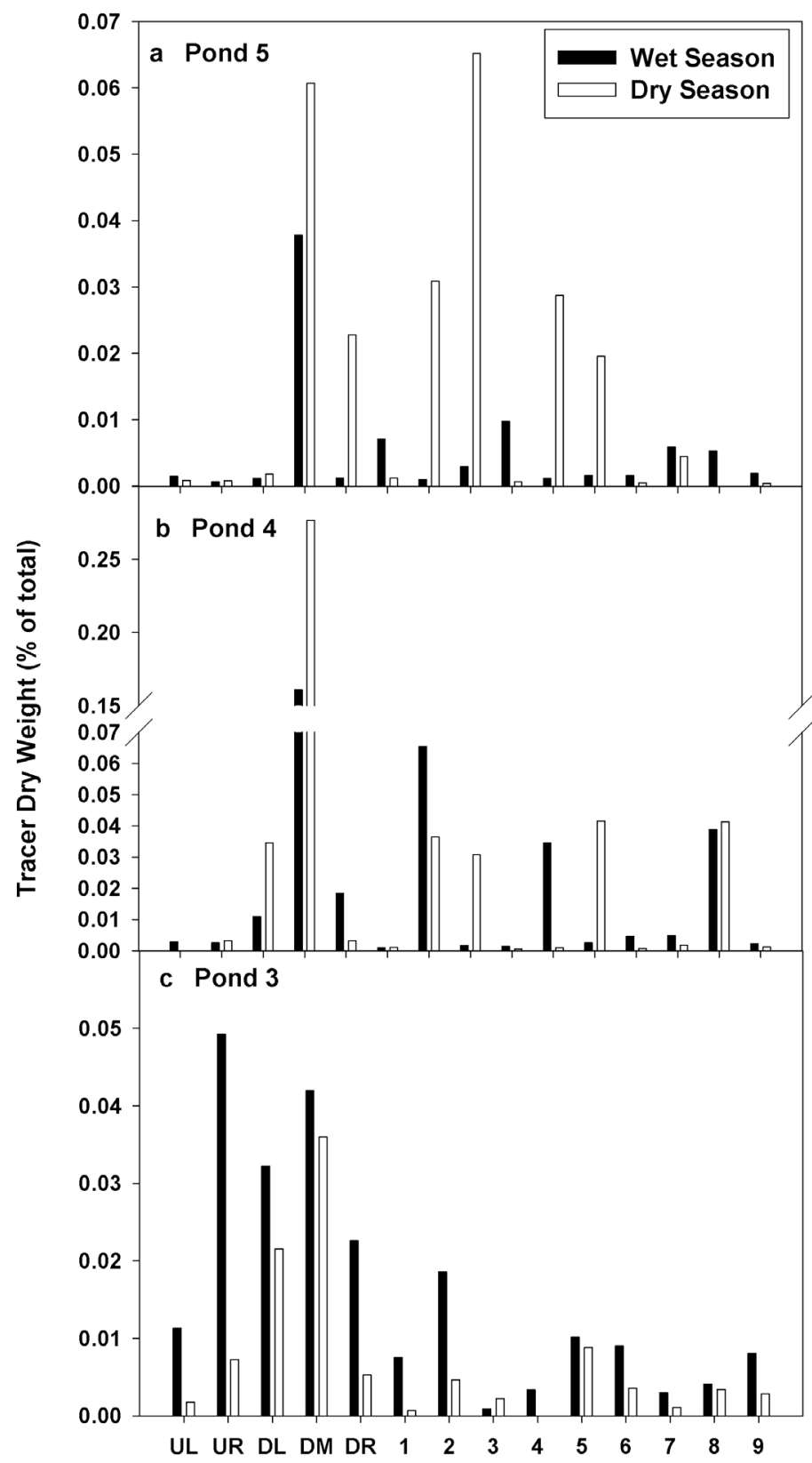

Figure 4. Differences in the amount of tracer (as \% weight of tracer released) captured by individual magnets between wet (dark circles, solid line) and dry season (open circles, dotted line) tracer experiments in Pond 5 (panel a), Pond 4 (panel b), and Pond 3 (panel c). 
The array of magnets positioned just after the pond inlet (Fig. 2) revealed considerable variability in tracer deposition among ponds (Fig. 5). For instance, wet season tracer dispersion was skewed towards the leftmost bank, from the perspective of downstream water flow, in Pond 3 and Pond 4 during the wet season (Fig. $5 \mathrm{c}$ and e). Meanwhile, tracer was evenly distributed across the Pond 5 inlet during the wet season (Fig. 5a). I observed a notable shift in tracer distribution farther into Pond 3 and Pond 4 during the dry season sampling as compared to wet season sampling (Fig. $5 \mathrm{~d}$ and f). In contrast, Pond 5 dry season tracer was concentrated closer to the pond inlet as compared to the diffuse distribution in the wet season (Fig. 5a and b). The proportion of tracer captured within Pond 4 and Pond 5 was up to three times greater than that captured in Pond 3 (Figs. 4 and 5).

\section{Fluxes and Pond Storage}

Estimated upstream fluxes of floc tracer were greater during the wet season sampling at all three pond sites, but $95 \%$ confidence intervals about the flux estimates suggest no significant seasonal difference (Table 2). Estimated downstream flux of tracer in Pond 3 was significantly greater during the wet season compared with the dry season; however, in Pond 4 and Pond 5, I no evidence of a seasonal difference in downstream flux. Tracer storage within Ponds 4 and 5 were not significantly different. Tracer velocity was estimated to be $1.55 \mathrm{~m} /$ day during the wet season and $1.63 \mathrm{~m} /$ day during the dry season (Table 1). 

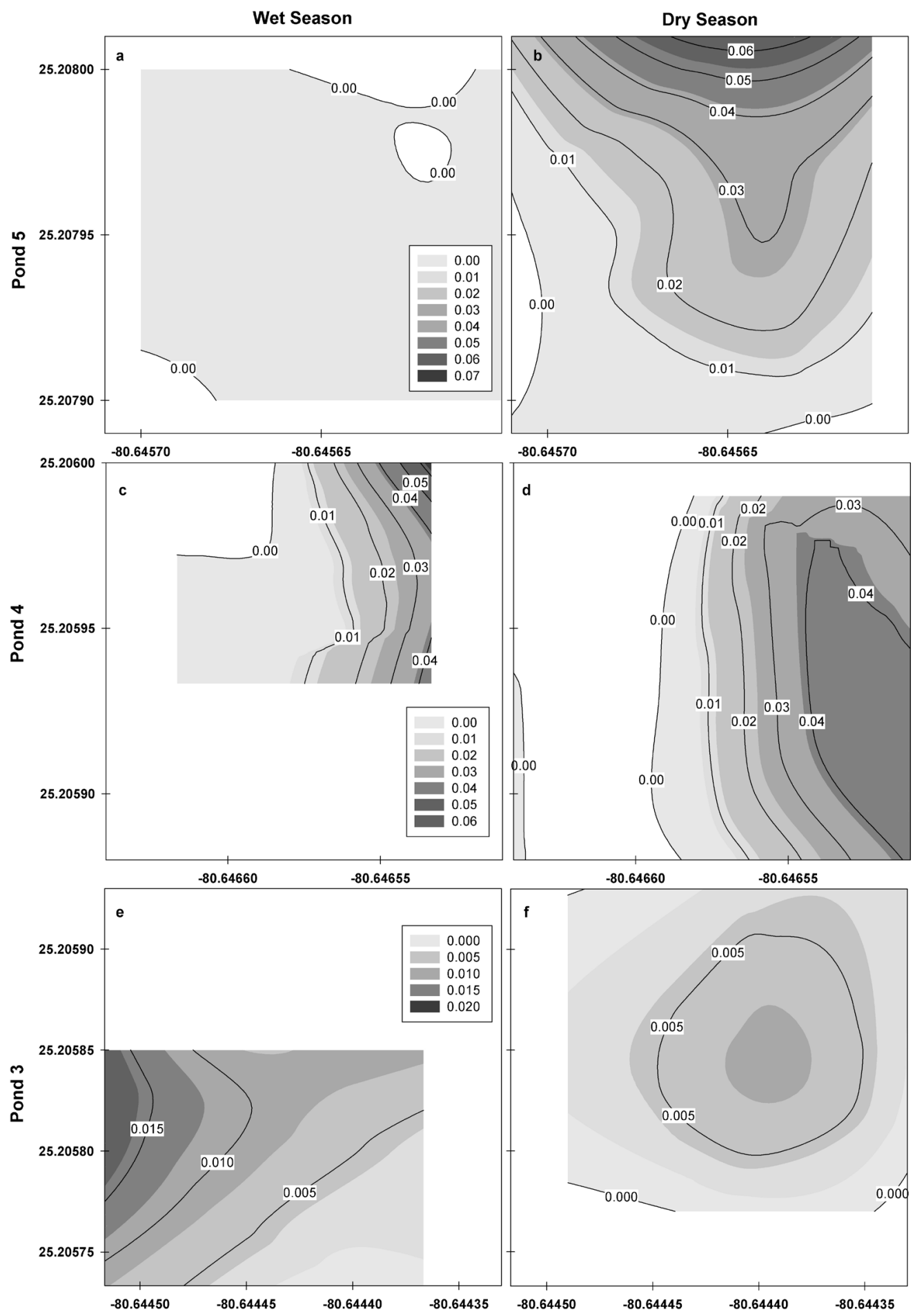

Figure 5. Contour plots showing distribution of $\%$ tracer mass within Pond 5 (panels a-b), Pond 4 (panels cd), and Pond 3 (panels e-f) across wet (left panels) and dry seasons (right panels). The domain and range of each figure (latitude and longitude in UTM coordinates) is positioned near the inlet of each pond and within the pond boundary. The extent of contour lines and interpolated shading is limited to the positioning of underwater sampling magnets during sampling. Note that water enters Pond 3 from a western direction (see Figure 1). 
Table 2. Estimated fluxes of flocculated detritus at three Taylor River pond sites. Flux error is based on $95 \%$ confidence intervals of mean tracer collected across each transect of magnets.

\begin{tabular}{|c|c|c|c|c|c|c|c|}
\hline \multirow{2}{*}{$\begin{array}{c}\text { Site } \\
\text { Pond } 3\end{array}$} & \multirow{2}{*}{$\begin{array}{c}\text { Season } \\
\text { Wet }\end{array}$} & \multicolumn{2}{|c|}{$\begin{array}{l}\text { Upstream Flux } \\
\text { (\% tracer / day) }\end{array}$} & \multicolumn{2}{|c|}{$\begin{array}{l}\text { Downstream Flux } \\
\text { (\% tracer / day) }\end{array}$} & \multicolumn{2}{|c|}{$\begin{array}{l}\text { Pond Storage } \\
\text { ( } \% \text { tracer / day) }\end{array}$} \\
\hline & & 0.637 & \pm 0.782 & 0.728 & \pm 0.248 & ----- & ----- \\
\hline & Dry & 0.095 & \pm 0.114 & 0.371 & \pm 0.308 & ----- & -.... \\
\hline \multirow[t]{2}{*}{ Pond 4} & Wet & 0.029 & \pm 0.004 & 0.292 & \pm 0.440 & 0.249 & \pm 0.397 \\
\hline & Dry & 0.012 & \pm 0.024 & 0.779 & \pm 1.260 & 0.747 & \pm 1.227 \\
\hline \multirow[t]{2}{*}{ Pond 5} & Wet & 0.015 & \pm 0.012 & 0.225 & \pm 0.402 & 0.147 & \pm 0.323 \\
\hline & Dry & 0.009 & \pm 0.001 & 0.328 & \pm 0.390 & 0.310 & \pm 0.372 \\
\hline
\end{tabular}

\section{Discussion}

\section{Taylor River Hydrology}

Freshwater delivery to Taylor River is driven by both seasonal and interannual variability in local precipitation and water management decisions (Light and Dineen 1994, Sklar et al. 2005, Childers et al. 2006, Koch et al. 2012). Analysis of a long-term record [1996-2010] of Taylor River discharge and water quality variables revealed a repeating, seasonal pattern of surface water discharge with higher wet seasons flow from July to January and lower dry season flow from February to June (Koch et al. 2012). However, during my study, I found that upstream Taylor River discharge was significantly lower during the December wet season than during the July dry season. Meanwhile, discharge measured downstream at the mouth of Taylor River exhibited a pattern similar to the long term data record. In addition, water velocity in central Taylor River showed higher variability, including a greater number of days of upstream water movement, during the wet season as compared to the dry season sampling week. In the Taylor River estuary, where tidal influence is negligible, reduced downstream surface 
water flow as a result of climatic or water management decisions allows wind-forced movement of water upstream (Davis et al. 2001, Sutula et al. 2003, Childers et al. 2006).

Childers et al. (2006) showed that El Niño/Southern Oscillation (ENSO) events correspond to a flattening of the typical, seasonal oscillation of precipitation and water flow in Everglades estuaries, whereby wet seasons become drier than normal and dry seasons become wetter than normal. The 2009 and early 2010 calendar years exhibited a high Multivariate ENSO Index (MEI). Therefore, it is possible that the hydrologic similarity between my sampling seasons can be partially attributed to dampening of seasonal hydrology by ENSO. Restoring freshwater delivery to southern Everglades estuaries by reducing water control structures should not only increase the magnitude of downstream discharge in Taylor River but also enhance existing seasonal fluctuations.

\section{Taylor River Floc Transport}

Given the hydrologic context of my study, it is not surprising that I found few seasonal differences in floc tracer dynamics in Taylor River. Notably, I recovered a significantly higher proportion of tracer on Pond 3 magnets during the wet season than during the dry season. This difference was driven largely by tracer captured on creek magnets rather than magnets stationed within the pond. Consequently, calculated fluxes

of tracer within the creek channel were greatest in magnitude during wet season sampling. Interestingly, upstream flux of tracer in the wet season was nearly double that of dry season, which corresponded to frequent days of upstream water velocity during the wet season sampling. 
The distribution of tracer within the ponds was notably even during the wet season sampling, especially in Ponds 4 and 5. In contrast, dry season distribution of tracer in Pond 4 was concentrated along the eastern bank of the pond. In Pond 5, tracer was concentrated near the inlet of the pond and extending centrally into the pond. This pattern was reversed in Pond 3, wherein tracer was found close to the pond inlet during the wet season but was more diffuse during the dry season. The contrasting tracer results exhibited between Pond 3 and the other Taylor River ponds may be explained by the unique configuration of the river channel just before Pond 3. For much of its reach, Taylor River flows in a southerly direction; however, just after Pond 4, the river abruptly turns eastward towards Pond 3 before resuming southerly flow. Furthermore, this study and others have noted that discharge is more variable and often an order of magnitude larger in the southern reach of Taylor River as compared to the upstream section (Koch et al. 2012). It is possible that this right-angle junction serves as a natural hydrologic breakpoint between the small-magnitude, low-variability flow of upstream Taylor River and the high-magnitude, high-variability flow of downstream Taylor River.

The higher wet season water velocity and depth in Taylor River likely led to a greater entrainment and wider dispersion of floc tracer as compared to the dry season. In addition, since the roughly $20 \mathrm{~cm}$-high cylindrical magnets sampled from the bottom of the creeks and ponds, a deeper water column in the wet season could allow some entrained tracer to pass over the magnets, resulting in decreased capture rates by my magnets. Larsen et al. (2009) report that the bed shear stress necessary to entrain Everglades floc is noticeably lower than that for more mineral-rich floc found in other 
wetlands. Thus, Everglades floc is particularly susceptible to entrainment with increases in water velocity.

Storage of floc tracer within Taylor River ponds during the dry season was roughly double that of storage during the wet season. Detritus from wetland vegetation has been proposed to be an important carbon source fueling estuarine production (Teal 1962, Odum and Heald 1975, Nixon 1980, Childers et al. 2000). In Taylor River, seasonal whole-system metabolic rates have been linked to the seasonal dynamics of freshwater delivery to the estuary (Koch et al. 2012). Furthermore, Koch et al. (2012) proposed that sustained net heterotrophy of Taylor River ponds is supported by a combination of stored organic sediments and allochthonous inputs of wetland detritus. Increasing freshwater flows, as part of Everglades restoration, may therefore reduce the accumulation of wetland-derived floc within Taylor River ponds. The magnitude of ecosystem heterotrophy within the river channel would decrease as less floc is captured in the ponded sections of the river. As a result, organic carbon subsidy to northeastern Florida Bay would increase.

\section{References}

Belicka, L.L., E.R. Sokol, J.M. Hoch, R. Jaffe, and J.C. Trexler. 2012. A molecular and stable isotope approach to investigate algal and detrital energy pathways in a freshwater marsh. Wetlands 32(3): 531-542.

Black, K.S., S. Athey, P. Wilson, and D. Evans. 2007. The use of particle tracking in sediment transport studies: a review. Coastal and Shelf Sediment Transport 274: 73-91.

Boyer, J. N., J. W. Fourqurean, and R. D. Jones. 1999. Seasonal and long-term trends in the water quality of Florida Bay (1989-1997). Estuaries 22: 417-430. 
Childers, D. L., J. W. Day Jr., and H. N. McKellar Jr. 2000. Twenty more years of marsh and estuarine flux studies: Revisiting Nixon (1980). In: [M.P. Weinstein and D.Q. Kreeger, eds.] Concepts and Controversies in Tidal Marsh Ecology, pp. 391-423.

Childers, D.L. 2006. A synthesis of long-term research by the Florida Coastal Everglades LTER Program. Hydrobiologia 569(1):531-544.

Childers, D.L., J.N. Boyer, S.E. Davis, C.J. Madden, D.T. Rudnick, F.H. Sklar. 2006. Relating precipitation and water management to nutrient concentrations in the oligotrophic "upside-down" estuaries of the Florida Everglades. Limnology and Oceanography 51:602-616.

Davis, S. E. III, D. L. Childers, J. W. Day Jr., D. T. Rudnick, F. H. Sklar. 2001. Wetlandwater column exchanges of carbon, nitrogen, and phosphorus in a southern Everglades dwarf mangrove. Estuaries 24(4): 610-622.

Droppo, I.G., G.G. Leppard, D.T. Flannigan, and S.N. Liss. 1997. The freshwater floc: a function relationship of water and organic and inorganic floc constituents affecting suspended sediment properties. Water, Air, and Soil Pollution 99: 43-54.

Droppo, I.G. 2001. Rethinking what contitues suspended sediment. Hydrological Processes 15: 1551-1564.

Duever, M.J., J.F. Meeder, L.C. Meeder, and J.M. McCollom. 1994. The climate of South Florida and its role in shaping the Everglades ecosystem. In: [S.M. Davis and J.C. Ogden, eds.] Everglades: The Ecosystem and its Restoration, pp. 225-248, St. Lucie Press, Delray Beach, FL.

Gaiser, E. E., L. J. Scinto, J. H. Richards, K. Jayachandran, D. L. Childers, J. C. Trexler, and R. D. Jones. 2004. Phosphorus in periphyton mats provides the best metric for detecting low-level P enrichment in an oligotrophic wetland. Water Research 38: 507516.

Gaiser, E.E., J.C. Trexler, J.H. Richards, D.L. Childers, D. Lee, A.L. Edwards, L.J. Scinto, K. Jayachandran, G.B. Noe, and R.D. Jones. 2005. Cascading ecological effects of low-level phosphorus enrichment in the Florida Everglades. Journal of Environmental Quality 34: 717-723.

Gaiser, E.E., A. Zafiris, P.L. Ruiz, F.A.C. Tobias, M.S. Ross. 2006. Tracking rates of ecotone migration due to salt-water encroachment using fossil mollusks in coastal South Florida. Hydrobiologia 569: 237-257.

Jaffé R., R. Mead, M.E. Hernandez, M.C. Peralba, O.A. DiGuida. 2001. Origin and transport of sedimentary organic matter in two subtropical estuaries: a comparative, biomarker-based study. Organic Geochemistry 32: 507-526. 
Koch, G.R., D.L. Childers, P.A. Staehr, R.M. Price, S.E. Davis, and E.E. Gaiser. 2012. Hydrological conditions control P loading and aquatic metabolism in an oligotrophic, subtropical estuary. Estuaries and Coasts 35: 292-307.

Larsen, L.G., J.W. Harvey, and J.P. Crimaldi. 2007. A delicate balance: ecohydrological feedbacks governing landscape morphology in a lotic peatland. Ecological Monographs 77(4): 591-614.

Larsen, L.G., J.W. Harvey, and J.P. Crimaldi. 2009. Morphologic and transport properties of natural organic floc. Water Resources Research 45: W01410.

Larsen, L.G. and J.W. Harvey. 2010. How vegetation and sediment transport feedbacks driver landscape change in the Everglades and wetlands worldwide. The American Naturalist 175(3): E66-E79.

Light, S. S. and J. W. Dineen. 1994. Water control in the Everglades: a historical perspective. In: [S.M. Davis and J.C. Ogden, eds.] Everglades: The Ecosystem and its Restoration. St. Lucie Press, Delray Beach, FL.

Liss, S.N., I.G. Droppo, D.T. Flannigan, and G.G. Leppard. 1996. Floc architecture in wastewater and natural riverine systems. Environmental Science and Technology 30: 680-686.

Mead R., Y. Xu, J. Chong, R. Jaffé. 2005. Sediment and soil organic matter source assessment as revealed by the molecular distribution and carbon isotopic composition of n-alkanes. Organic Geochemistry 36: 363-370.

McVoy C. W. 2011. Landscapes and hydrology of the predrainage Everglades. University Press of Florida, Gainesville.

Neto R.R., R.N. Mead, J.W. Louda, R. Jaffé. 2006. Organic biogeochemistry of detrital flocculent material (floc) in a subtropical, coastal wetland. Biogeochemistry 77: 283-304.

Nixon, S. W. 1980. Between coastal marshes and coastal waters - a review of twenty years of speculation and research on the role of salt marshes in estuarine productivity and water chemistry. In: Estuarine and wetland processes with emphasis on modeling, Plenum Publishing, NY. p 437-525.

Noe, G.B., D.L. Childers, R.D. Jones. 2001. Phosphorus biogeochemistry and the impact of phosphorus enrichment: why is the Everglades so unique? Ecosystems 4: 603-624.

Noe, G.B., D.L. Childers, A.L. Edwards, E. Gaiser, K. Jayachandran, D. Lee, J. Meeder, J. Richards, L.J. Scinto, J. C. Trexler, and R.D. Jones. 2002. Short-term changes in 
phosphorus storage in an oligotrophic Everglades wetland ecosystem receiving experimental nutrient enrichment. Biogeochemistry 59: 239-267.

Odum, E. P. 1968. A research challenge: evaluating the productivity of coastal and estuarine water. In: Keiffner, E. (ed.) Proceedings of the Second Sea Grant Conference, Univ. of Rhode Island, Newport, Rhode Island, p 63-64.

Odum, E.P. 1969. The strategy of ecosystem development. Science 164: 596-604.

Odum, W.E. and E.J. Heald. 1975. The detritus-based food web of an estuarine community. In: [L.E. Cronin, ed.] Estuarine Research, Vol. 1. Academic Press, New York

Pisani, O., Y. Yamashita, and R. Jaffé. 2011. Photo-dissolution of flocculent, detrital material in aquatic environments: contributions to the dissolved organic matter pool. Water Research 45: 3836-3844.

Ross, M.S., J.F. Meeder, J.P. Sah, P.L. Ruiz, and G.J. Telesnicki. 2000. The Southeast saline Everglades revisited: 50 years of coastal vegetation change. Journal of Vegetation Science 11: 101-112.

Sklar, F.H., M.J. Chimney, S. Newman, P. McCormick, D. Gawlik, S. Miao, C. McVoy, W. Said, J. Newman, C. Coronado, G. Crozier, M. Korvela, and K. Rutchey. 2005. The ecological-societal underpinnings of Everglades restoration. Frontiers in Ecology and the Environment 3: 161-169.

Sutula, M. A., B. C. Perez, E. Reyes, D. L. Childers, S. Davis, J. W. Day Jr., D. Rudnick, F. Sklar. 2003. Factors affecting the spatial and temporal variability in material exchange between the southern Everglades wetlands and Florida Bay (USA). Estuarine, Coastal and Shelf Science 57: 757-781.

Teal, J.M. 1962. Energy flow in the salt marsh ecosystem of Georgia. Ecology 43(4): 614-624.

Troxler, T.G. and J.H. Richards. 2009. $\delta 13 \mathrm{C}, \delta 15 \mathrm{~N}$, carbon, nitrogen, and phosphorus as indicators of plant ecophysiology and organic matter pathways in Everglades deep slough, Florida, USA. Aquatic Botany 90(2): 129-136.

Vitousek, P. 1982. Nutrient cycling and nutrient use efficiency. American Naturalist 119(4): 553-572.

Vitousek, P.M. and R.L. Sanford, Jr. 1986. Nutrient cycling in moist tropical forest. Annual Review of Ecology and Systematics 17: 137-167. 
Williams, A.J. and J.C. Trexler. 2006. A preliminary analysis of the correlation of foodweb characteristics with hydrology and nutrient gradients in the southern Everglades. Hydrobiologia 569: 493-504.

Wood, A. 2005. Dynamics of detrital particulate organic material in the ridge and slough landscape of the Everglades. Master's Thesis, Florida International University. 


\section{Conclusions}

Everglades estuaries should experience an increase in freshwater delivery as a result of extensive, $\$ 8$ billion Everglades restoration plans. In this dissertation research, I investigated estuarine ecosystem function in Taylor River, a southern Everglades estuary, with the goal of using existing wet/dry subtropical seasonality to investigate relationships between hydrological and ecological variables, organized around the central theme: how will increased delivery of freshwater to Taylor River, an estuary in the southern Everglades, affect aquatic ecosystem function? Specifically, I examined seasonal dynamics of flocculent detritus transport and ecosystem metabolism within Taylor River. My flocculent detritus transport study was driven by the central question: how do seasonal changes in surface water hydrology (namely water velocity and water depth) control the transport of flocculent detrital material in Taylor River? Using a paramagnetic sediment tracer as a surrogate for natural floc advective transport, I found that the downstream flux of floc material was seasonally pulsed with the greatest magnitude occurring during early wet season flushing of Taylor River. Downstream velocity of floc tracer was estimated to be approximately $1.5 \mathrm{~m} /$ day. Diminished freshwater delivery during the late wet season and dry season did not appear to influence upstream movement of floc, which remained minimal, however these results were sitespecific. Lastly, I found that storage of floc materials within Taylor River ponds was driven by large inputs relative to small or negligible outputs. Thus, floc storage is greatest during early wet season when these materials are flushed into ponded sections of Taylor River. 
I also investigated aquatic ecosystem metabolism in Taylor River in order to understand how the seasonality of the hydrologic regime controlled whole-system metabolism by regulating the supply of limiting phosphorus (P). I used free-water, diel changes in dissolved oxygen coupled with modeled estimates of physical gas exchange at the air-water interface to calculate daily estimates of Taylor River pond metabolism. I found that aquatic gross primary production (GPP) was greatest during the euhaline estuarine dry season, matching low freshwater inputs and high $\mathrm{P}$ conditions. Furthermore, GPP and ecosystem respiration (R) were tightly coupled in Taylor River, suggesting that autochthonous organic matter $(\mathrm{OM})$ is more labile than allochthonous inputs. Ecosystem R did not appear to respond to wet season inputs of floc material. Lastly, Taylor River aquatic ecosystems are net heterotrophic, driven by low overall primary productivity and high inputs and/or storage of allochthonous OM.

In Taylor River, which is isolated from marine tidal influence and P supply by shallow Florida Bay, groundwater and benthic sources of $\mathrm{P}$ appear to be critical in regulating aquatic ecosystem function. Loss of freshwater head as upstream water delivery subsides during estuarine dry seasons allows discharge of high-P groundwater as well as wind-forced incursions of high-salinity Florida Bay water into Taylor River. Rising salinity conditions may contribute to the release of $\mathrm{P}$ from estuarine sediments. These benthic P sources directly fuel ecosystem GPP and R. Enhanced R by labile autochthonous OM may additionally "prime" the decomposition of more refractory OM, which remineralizes additional P into the Taylor River water column. These processes are exaggerated by high water residence times during the estuarine dry season, allowing a positive feedback loop that leads to repeatedly observed high P concentrations during the 
dry season. This positive feedback loop is eventually stabilized by the return of freshwater flows during the estuarine wet season, flushing out existing high-P surface water, decreasing water residence times, and reduces the significance of benthic $\mathrm{P}$ supplies.

My dissertation research supports central hypotheses developed as a result of extensive Florida Coastal Everglades Long-Term Ecological Research (FCE LTER) that increasing freshwater delivery to Everglades estuaries will enhance oligotrophy of these coastal ecosystems. I show evidence that management of Everglades freshwater resources has observable impacts on downstream estuarine ecosystem function and that future management decisions need to take this hydrological and ecological linkage into consideration. 
VITA

GREGORY R. KOCH

June 14, 1982

Born, Reading, Pennsylvania

2000-2004

B.S., Biology

Albright College

Reading, Pennsylvania

2006-2012

Doctoral Candidate

Florida International University

Miami, Florida

\section{PUBLICATIONS}

Spasojevic M., R. Aicher, G.R. Koch, E. Marquardt, N. Mirotchnick, T. Troxler, and S. Collins. 2010. Fire and grazing in a mesic tallgrass prairie: impacts on plant species and functional traits. Ecology 91(6): 1651-1659.

Staehr P. A., D. Bade, M. C. Van de Bogert, G. R. Koch, C. Williamson, P. Hanson, J. J. Cole, and T. Kratz. 2010. Lake metabolism and the diel dissolved oxygen technique: state of the science. Limnology and Oceanography: Methods 8: 628-644.

Koch, G.R., D.L. Childers, P.A. Staehr, R. Price, S.E. Davis, and E. E. Gaiser. 2012. Hydrological conditions control P loading and aquatic metabolism in an oligotrophic, subtropical estuary. Estuaries and Coasts 35: 292-307.

Koch, G.R., O. Pisani, J.R. Wozniak, D.L. Childers, E.E. Gaiser, and S.E. Davis. In Review. Analysis of flocculent detritus in Everglades wetlands using multiple collection methods. Wetlands 